PNL-3559

UC-70

\title{
Initial Waste Package Interaction Tests: Status Report
}
J. W. Shade
D. J. Bradley

December 1980

Prepared for the U.S. Department of Energy under Contract DE-AC06-76RLO 1830

Pacific Northwest Laboratory

Operated for the U.S. Department ot Energy by Battelle Memorial Institute 
This report was prepared as an account of work sponsored by the United States Covernment. Veither the United States nor the Department of Energy, nor any of their empioyees, nor any of their contractors. subcontractors, or their employees, makes any warranty, express or implied, or assumes any legal liability or responsibility for the accuracy. completeness or usefulness of any information, apparatus. product or process disclosed, or represents that its use would not infringe privately owned rights.

The views, opinions and conclusions contained in this report are those of the contractor and do not necessarily represent those of the United States Covernment or the United States Department of Energy.

\author{
PACIFIC NORTHWEST LABORATORY \\ operated by \\ BATTELLE \\ for the \\ UNITED STATES DEPARTMENT OF ENERCY \\ Under Contract DE-AC06-76RLO 1830
}

\author{
Printed in the United States of America \\ Available trom \\ National Technicai Iniormation Service \\ United States Department of Commerce \\ 5285 Port Royal Road \\ Springtield. Virginia 22751
}

Price: Printed Copy s

$\therefore$ Microtiche $\$ 3.00$

$\begin{array}{cc}\text {-Pages } & \begin{array}{c}\text { NTIS } \\ \text { Selling Price }\end{array} \\ 001-025 & \$ 4.00 \\ 026-050 & \$ 4.50 \\ 051-075 & \$ 5.25 \\ 076-100 & \$ 6.00 \\ 101-125 & \$ 6.50 \\ 126-150 & \$ 7.25 \\ 151-175 & \$ 8.00 \\ 176-200 & \$ 9.00 \\ 201-225 & \$ 9.25 \\ 226-250 & \$ 9.50 \\ 251-275 & \$ 10.75 \\ 276-300 & \$ 11.00\end{array}$


PNL -3559

UC -70

\section{5}

INITIAL WASTE PACKAGE INTERACTION

TESTS: STATUS REPORT

J. W. Shade

D. J. Bradley

December 1980

Prepared for

the U.S. Department of Energy

under Contract DE-AC06-76RLO 1830

Pacific Northwest Laboratory

Richland, Washington 99352 
$\therefore$

$r$ 


\section{SUMMARY}

Waste package interaction tests were initiated in FY 80 as part of the Waste Rock Interaction Technology (WRIT) program. These package tests represent a natural extension of previous and concurrent waste-solution interaction studies. This report describes the results of some initial investigations of the effects of rock media on the release of simulated fission products from a single waste form, PNL reference glass 76-68. The tests are intended to serve as a guide for the design of future experiments with the objective of supporting the development of a source-term release model, and to gain some insight into expected behavior in scaled-up, fully radioactive, large volume system tests.

All tests assemblies contained a minicanister prepared by pouring molten, U-doped 76-68 glass into a $2 \mathrm{~cm}$ diamter stainiess steel tube closed at one end. The tubes were cut to 2.5 to $7.5 \mathrm{~cm}$ in length to expose a flat glass surface rimmed by the canister wall. A cylindrical, whole rock pellet, cut from one of the rock materials used, was placed on the glass surface then both the canister and rock pellet were packed in the same type of rock media ground to about $75 \mu \mathrm{m}$ to complete the package. Rock materials used were a quartz monzonite from the Climax Stock at the Nevada Test Site, basalt from the Umtanum flow at Hanford, and bedded salt from southeastern New Mexico. These packages were run from 4 to 6 weeks in either $125 \mathrm{ml}$ digestion bombs or $850 \mathrm{ml}$ autoclaves capable of direct solution sampling, at either $250^{\circ}$ or $150^{\circ} \mathrm{C}$. Digestion bomb pressures were the vapor pressure of water, 600 psig at $250^{\circ} \mathrm{C}$, and the autoclaves were pressurized at 2000 psig with an argon overpressure. The solution to package mass ratio was 0.5 in the digestion bombs and about 3.0 in the autoclaves.

Differences between pre and post test brine compositions in salt package tests suggests that salt recrystallization during the test leads to a redistribution of elements between salt and brine along with the removal of some elements from the glass and canister. In general $\mathrm{Mg}$ and $\mathrm{Cs}$ are enriched in the brine while $\mathrm{Ca}$ and $\mathrm{Sr}$ are concentrated in recrystallized salt. $\mathrm{Ni}$ and $\mathrm{Cr}$, probably from the canister, and $2 n$, from the glass, become enriched in the liquid. These effects were not as pronounced in the large volume autoclave 
tests as in the digestion bomb tests, but solution $\mathrm{pH}$ values in both tests were lowered to about 3.0 from the initial value of 5.5 . Solution compositions from granite and basalt package post test fluid suggest that dissolved $\mathrm{SiO}_{2}$ is derived from quartz in the granite packages, and from interstitial volcanic glass in basalt. It was also apparent from $\mathrm{SiO}_{2}$ concentrations that steady state conditions had not been achieved. Soluble $C$ s concentrations in the granite and basalt tests were reduced relative to the salt package tests and previous glass-water hydrothermal tests, but basalt and granite appear to have little effect on Mo and $B$ release.

Examination of glass surfaces by scanning electron microscopy (SEM) revealed a variety of alteration products some of which have been tentatively identified on the basis of their characteristic x-ray spectra. Uraniumbearing spheres and zinc silicate (Willemite?, $\mathrm{Zn}_{2} \mathrm{SiO}_{4}$ ) crystals were observed in packages that had been exposed to a vapor phase but were not found in packages that remained submersed in a liquid phase during the run. Presumably the latter remained in a more reducing environment than the former. $X$-ray photoelectron spectroscopy (XPS) of the rock pellet surfaces also revealed that $U$ was present in rocks which contacted the vapor phase but $U$ was not found on rock surfaces which contacted only the liquid phase. Other phases present on rock surfaces in contact with either vapor and liquid phases include calcium phosphate (Apatite?) and calcium sulfate (Gypsum?) and on one occasion, a zirconium silicate (Zircon?).

In general, the solution chemistry of these initial package tests suggests that the rock media is the dominant controlling factor and that rockwater interaction may be similar to that observed in some geothermal areas. In no case was uranium observed in solution above $15 \mathrm{ppb}$. The observed leach rates of $U$ glass not in contact with potential sinks (rock surfaces and alteration products) have been observed to be considerably higher. Thus the use of leach rates and $U$ concentrations observed from binary leach experiments (waste-form water only) to ascertain long term environmental consequences appear to be quite conservative compared to actual $U$ release in the waste package experiments. Further evaluation, however, of fission product transport behavior and the role of alteration phases as fission product sinks is required. 


\section{CONTENTS}

SUMMARY

i i i

FIGURES

TABLES

ACKNOWLEDGEMENT

INTRODUCTION

TEST MATERIALS AND PROCEDURE

TEST PACKAGE ASSEMBLY

TEST OPERATION

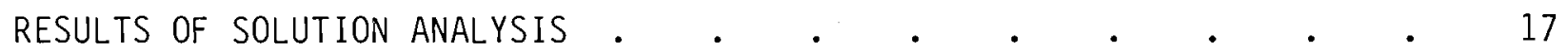

SOLID COMPONENT ANALYSIS .

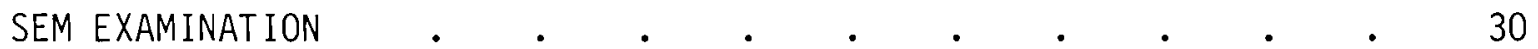

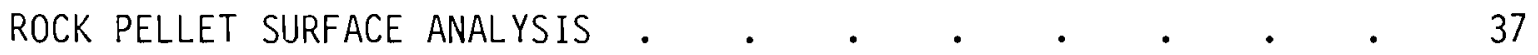

DISCUSSION

COMPARISON WITH GLASS-WATER INTERACTION .

COMPARISON WITH GEOTHERMAL DATA

CONCLUSIONS

REFERENCES

APPENDIX A

APPENDIX B 


\section{FIGURES}

1. Basalt, Granite, and Salt Digestion Bomb components Used

in Waste Package Tests.$\quad \cdot \quad \cdot \quad \cdot \quad \cdot \quad \cdot \quad \cdot$

2. Schematic of Test Package Assembly Used in Autoclave Tests . . 9

3. $125 \mathrm{ml}$ Digestion Bomb Used in Waste Package Tests . . . . 10

4. Direct Sampling Autoclave used in Waste Package Tests . . . 11

5. Digestion Bomb Packages Immediately After $250^{\circ} \mathrm{C}, 30$ Day Run . . 14

6. Components of Granite and Salt Packages Immediatley

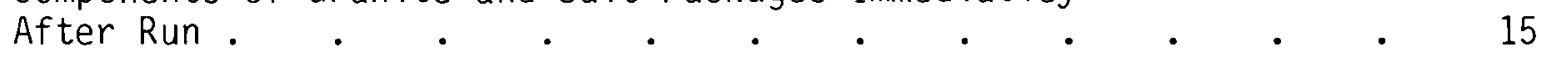

\begin{tabular}{l} 
7. NaCl solubility Along the Three Phase Liquid-Vapor-NaCl \\
Curve \\
\hline
\end{tabular}

8. Amorphous and Crystalline Silica Solubility . . . . . . . 29

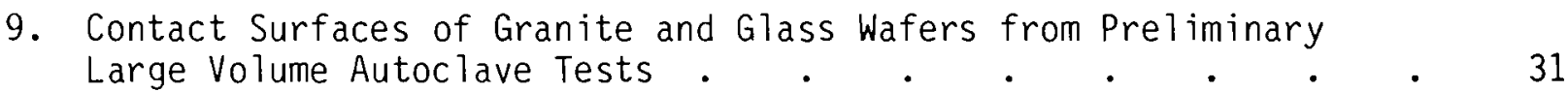

10. Glass-Rock Surfaces from Granite Digestion Bomb Tests

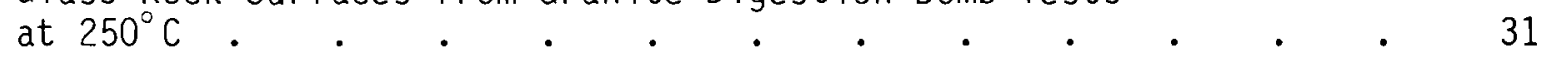

11. Glass-Rock Surfaces from Basalt Digestion Bomb Tests at $250^{\circ} \mathrm{C} . \quad . \quad . \quad . \quad . \quad . \quad . \quad . \quad . \quad . \quad . \quad 32$

12. Glass Surface from Salt Digestion Bomb Test-granite package . . 32

13. Glass Surface from Preliminary Autoclave Test-Package Exposed to Vapor Phase
(a) Glass-Canister Surface at Low Magnification . $\quad$ • $\quad$ • $\quad 34$
(b) Zinc silicate crystals and uranium spheres .
(c) Silica gel precipitate and Calcium Phosphate Needles . $\quad 36$

14. Polished Cross Section of Canister at Mid-Height At Area of vertical Slit. Granite-Digestion Bomb Package . .

15. Fracture Area in Glass Near Vertical Slit. Magnified from Figure 14. Note Uranium Migration from Glass Into Fracture.

16. Glass-Rock Powder Interface Area Magnified from Figure 14. Note Uranium Migration Into Rock Material $. \quad . \quad . \quad . \quad . \quad 39$

17. XPS Spectra from Surface of Granite Pellet Exposed to a Vapor Phase. (Lower) Compared with Original Pellet (Upper). Note Presence of Uranium on Autoclave Pellet. 
18. Solution Concentrations as a Function of Time for $B$ and Mo from Waste Package Tests Compared With 76-68 Glass Without Rock

Media Present at $250^{\circ} \mathrm{C}, 2000 \mathrm{psig}$. $\quad$. . . . . .

19. $\mathrm{Na}$ and Si Solution Concentrations as a Function of Time for Waste Package Tests Compared With 76-68 Glass Without Rock Media Present at $250^{\circ} \mathrm{C}, 2000 \mathrm{psig}$. . . . . .

20. Cs Solution Concentrations as a Function of Time for Waste Package Tests Compared with 76-68 Glass Without the Presence of Rock Media at $250^{\circ} \mathrm{C}, 2000$ psig . . . .

21. Stability Diagram for Selected Alkali Minerals in Terms of $\mathrm{aNa}^{+} / \mathrm{aH}^{+}$and $\mathrm{aK}^{+} / \mathrm{aH}^{+}$activity ratios at $260^{\circ} \mathrm{C}$

22. Stability Diagram for Selected Potassium and Calcium Alteration Minerals in Terms of $\mathrm{aCa}^{++} /\left(\mathrm{aH}^{+}\right)^{2}$ and $\mathrm{aK}^{+} / \mathrm{aH}^{+}$activity Ratios

A.1. Alteration Phases on the Glass Surface from Salt Package Digestion Bomb Tests Probably a Calcium Sulfate with Interference from Silica Gel

A.2. Alteration Phases on the Glass Surface From Salt Package $850 \mathrm{ml}$ Autoclave Tests. The Dominant Phases are Calcium Sulfate, Sodium Chloride, Silica Gel and Possibly Polyhalite

A.3. Alteration Phases on the Glass Surface From Salt Package $850 \mathrm{ml}$ Autoclave Tests. Calcium and Potassium Sulfates are Present

A.4. Metal-Rich Phases on Glass Surface Near Canister Wall from Granite Package Digestion Bomb Test

A.5. Alteration Phases on Canister Rim From Granite (Upper) and Basalt (Lower) Digestion Bomb Tests. Ca-Rich Cubic Crystal May Be Fluorite, $\mathrm{Fe}$ and $\mathrm{Cr}$ Peaks are from Canister Below the Silica Gel Coating . . . . . . . . . . A.6

A.6. Alteration Phases on Glass Surface from Basalt Package

A.7. Alteration Phases On Glass Surface from Granite Package Autoclave Test (Upper), Granite Package-Digestion Bomb (Middle), and Basalt Package-Digestion Bomb (Lower). The Spectra to Right Refer to the Crystals Shown

B.1. XPS Spectra from Surface of Granite Pellet Run Submersed in Liquid Phase In Digestion Bomb Test. Lower Spectra is Shown in an Expanded Scale in the Vicinity of Uranium Peaks $(-386 \mathrm{eV}$ and $-397 \mathrm{eV})$. No Evidence of Uranium Found on Surface 
B.2. XPS Spectra from Surface of Granite Pellet Exposed to a Vapor Phase in Autoclave Test. Compare with Figure B.1 and Note

Presence of $U$ Peaks

B.3. XPS Spectra of Original Basalt Pellet (Upper) and Recrystallized

Salt Pellet (Lower) Removed from a Salt Package Test . . . B.4

B.4. XPS Spectra of Basalt Pellet Exposed to a Vapor Phase in a

Package Test. Lower Spectra is an Expanded Scale in

Vicinity of Uranium Peaks. Compare with Figure B.2 for

Similar Occurrence in Granite Packages . . . . . . . B.5

B.5. XPS Spectra of a Basalt Pellet Run Submersed in a Liquid Phase in a Digestion Bomb Test. No Evidence of $U$ Found. Compare With Figure B.48 and Figure B.1 


\section{TABLES}

1. Composition of 76-68 Glass . . . . . . . . . . 5

2. Comparison of ICP Analyses of Granite and Basalt Standards

With Accepted Values. . . . . . . . . . 6

3. Bulk Compositions of Granite and Basalt Used in Waste

Package Tests . . . . . . . . . . . . 7

4. Teflon Digestion Bomb and Direct Sampling Autoclave Packages . 12

5. Composition of Brines from Teflon Digestion Bomb Tests

$(30$ Days $) \mu \mathrm{g} / \mathrm{ml}$ •

6. Brine Compositions From $850 \mathrm{ml}$ Direct Sample Autoclave Runs

(c) $250^{\circ} \mathrm{C} / 2000 \mathrm{psig}$ Argon, $\mu \mathrm{g} / \mathrm{ml}$. . . . . . . . . 19

7. Solution Compositions from Tefion Digestion Bomb Tests, 30 Days, $\mu \mathrm{g} / \mathrm{ml}$ •

8. Composition of Solutions Extracted at $250^{\circ} \mathrm{C} / 2000 \mathrm{psi}$ from $850 \mathrm{ml}$ Autoclave Runs, $\mu \mathrm{g} / \mathrm{ml}$, (Series 1) Initial Solution DI Water, Umtanum Basalt Package . . . . . . • . . . 21

9. Composition of Solutions Extracted at $250^{\circ} \mathrm{C} / 2000$ psig from $850 \mathrm{ml}$ Autoclave Runs, $\mu \mathrm{g} / \mathrm{ml}$, (Series 1) Initial Solution DI Water, NTS Granite Package . . . . . . . . .

10. Cation-Anion Concentrations of Cooldown Autoclave Liquors From Series I $850 \mathrm{ml}$ Autoclave Tests, $\mu \mathrm{g} / \mathrm{ml}$. . . . . 23

11. Solution Composition from Series 2 Direct Sampling Autoclave Runs Granite Matrix, $\mu \mathrm{g} / \mathrm{ml}, 250^{\circ} \mathrm{C} / 2000 \mathrm{psig} . . .5$.

12. Solution Composition from Series 2 Direct Sampling Autoclave Runs Basalt Matrix, $\mathrm{kg} / \mathrm{ml}, 250^{\circ} \mathrm{C} / 2000 \mathrm{psig} . . .5$.

13. Series I Solution Concentrations During Autoclave Cooldown, $\mu \mathrm{g} / \mathrm{ml}$

14. Comparison of Three Week Waste Package Compositions With Geothermal Solution Compositions from Similar Rock Types and Temperature. $\mu \mathrm{g} / \mathrm{ml}$. 


\section{ACKNOWLEDGEMENT}

We gratefully acknowledge the contributions of a number of individuals in this study. ICP and IC analyses of the solutions were capably performed by Mr. Frank Hara and Mr. Marty Cole. SEM analys is was performed by Mr. James Colemen and the XPS survey was made by Dr. Larry Pederson. Mr. Norm Stice and Ms. Rebbeca Smith conducted the autoclave and digestion bomb tests respectively. Mr. R. C. Britton prepared the waste packages and followed the analytical work. We are especially appreciative of the critical comments and helpful suggestions of Dr Dhanpat Rai, Dr Ray Turcotte and Mr. Jeff Serne. 


\section{INTRODUCTION}

As part of continuing studies on waste management sponsored by the Department of Energy (DOE), the Pacific Northwest Laboratory (PNL) has been conducting the Waste/Rock Interactions Technology Program (WRIT) for the Office of Nuclear Waste Isolation (ONWI). The purpose of this program is to gather and interpret data on the release and subsequent migration of radionuclides in the event nuclear-waste forms stored in a geologic repository come into contact with groundwater.

Information concerning the release of radionuclides from candidate nuclear-waste forms and waste packages is needed to evaluate deep geologic disposal concepts. Contact of nuclear wastes by groundwater is the most likely process whereby radioisotopes may be made available for transport (de Marsily et al. 1977; U.S. Environmental Protection Agency 1978; Bredehoeft 1978). Through several different laboratory testing techniques, elemental leach data were obtained for interpretation and assessment of waste form/solution interactions (Bradley 1979, 1980, Katayama 1979, 1980). These tests constituted the first step in a progressive overall test plan working towards understanding radionuclide release from more and more complex systems simulating geologic disposal of nuclear wastes. The reports listed above detail our results to date in ongoing waste-form/solution interaction studies.

This report is the first in a series on the next stage of studies on radionuclide release - that of small scale systems simulating waste package disposal. These tests were performed using waste glass, (of the same composition as used in the waste form/solution studies) and three host rock media types: South East New Mexico bedded salt, Umtanum Basalt (Hanford) and Climax Stock Granite (Nevada Test Site). The tests use the waste glass in a small (minicanister) container of stainless steel, simulating that used for process full scale processes (Bonner 1980) PNL-3375. The waste canister was "breached" by cutting a verticle slit to simulate a failed canister. This canister was then put in contact with the host rock materials. Engineered barriers were not used in these tests because of the small size (19 mm $\times 50 \mathrm{~mm}$ ) and because barrier programs have not narrowed down the range of candidates to 
allow a scientifically chosen material to be used. These materials will be used in the next stage of our tests which uses intermediate scale $\left(\simeq 3^{\prime \prime} \times 18^{\prime \prime}\right)$ waste packages.

The scope of the investigations reported in this document is limited to preliminary tests at $150^{\circ}$ and $250^{\circ} \mathrm{C}$. Using only one waste form, PNL reference glass 76-68 doped with $\mathrm{UO}_{2}$, and three rock types. As such, they represent only a starting point for waste package systems investigations. Future studies will include similar tests using additional repository components as well as specific experiments designed to support source term model development. Part of the emphasis of these initial experiments is to gain some general information on fission product mobility in complex chemical systems under a hypothetical flooded repository accident condition and to attempt to identify some of the dominant controls on the system. A basis for these studies is found in previous waste glass-solution studies and in both geothermal and ore deposit geochemistry investigations. Only a few attempts have been made to combine these types of investigations so the behavior of fission product elements in such systems is largely unknown.

This report describes the behavior of some of the fission products released from 76-68 glass under waste package hydrothermal conditions and compares them with previous glass-water interaction studies. A preliminary attempt has been to determine element mobility and to characterize secondary alteration phases that may serve as a fission product sink. A limited interpretation of the solution data is made in terms of known hydrothermal alteration equilibria and some preliminary insight into possible required modifications to existing geochemical models is provided. 


\section{TEST MATERIALS AND PROCEDURE}

Minicanisters of uranium-doped 76-68 glass were prepared by pouring molten glass into $19 \mathrm{~mm}$ diameter stainless steel tubes closed at one end with a welded end cap. The glass was melted at $1100^{\circ} \mathrm{C}$ and poured into tubes held at $600^{\circ} \mathrm{C}$. The tubes were cooled slowly through the glass transition range followed by an anneal. The open end of the tubes was cut off so that the glass surface and canister walls were flush. At the time the open end of the tubes were faced, a $6 \mathrm{~mm}$ thick section of the tube was cut to form a wafer of glass rimmed by the canister wall. A slit, about $3 \mathrm{~mm}$ wide, was cut through the canister wall in the axial direction to expose the glass and to simulate a ruptured canister. The length of the minicanisters used in the waste package tests ranged from 25 to $50 \mathrm{~mm}$. A photograph of three minicanisters along with other test components are shown in Figure 1. The composition of 76-68 glass is given in Table 1 .

The rock components used in the waste package tests were a quartz monzonite from the Nevada Test Site Climax Stock, referred to as "granite", a tholeitic basalt from the Umtanum flow of the Grande Rhonde Formation at Hanford, referred to as "Umtanum Basalt", and a sample of bedded salt from Southeast New Mexico. The granite has been used previously for sorption tests and both the mineralogy and composition have been described by Ames (1978). The major rock-forming minerals are plagioclase feldspar (47\%), of oligoclaseandesine composition, microcline (15\%), quartz (25\%) and biotite (10\%). Small amounts of apatite and pyrite are also present along with trace amounts of sphene. The Umtanum Basalt is similar to the Sentinal Gap basalt described by Ames (1978) and consists primarily of intermediate plagioclase and augitic pyroxene with minor ilmenite and magnetite. It is a fine grained basalt with crystallite sizes on the order of 0.1 to $0.01 \mathrm{~mm}$ and can consist of up to $30 \%$ interstitial glass which generally is an iron-bearing alkali silicate. Vug fillings are small and consist of calcite, and zeolites, with nontronite (NaFe montmorillonite clay) developed on fracture surfaces. The Umtanum Basalt is being considered as the BWIPP repository host rock at Hanford. The mineralogy of the bedded salt has been described by Lambert (1980). His visual estimate yields about $88 \%$ Halite ( $\mathrm{NaCl}), 4 \%$ Sylvite $(\mathrm{KCl})$ and $8 \%$ Polyhalite 


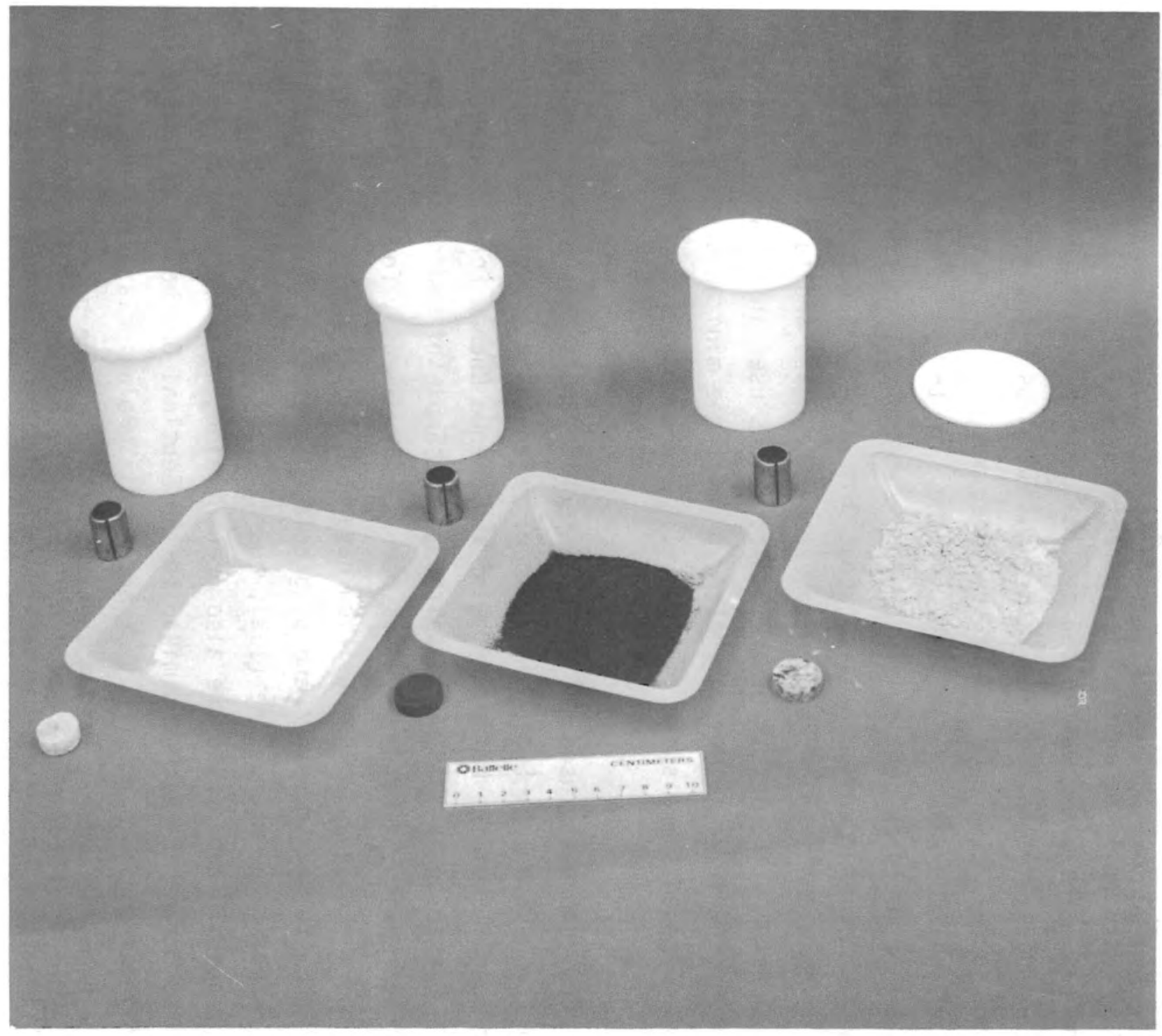

FIGURE 1. Basalt, Granite, and Salt Digestion Bomb Components Used in Waste Package Tests 
TABLE 1. Composition of 76-68 Glass

\begin{tabular}{|c|c|c|c|}
\hline Oxides & Wt\% & Oxides & $W t \%$ \\
\hline $\mathrm{Rb}_{2} \mathrm{O}$ & 0.13 & $\mathrm{Pr}_{6} \mathrm{O}_{11}$ & 0.53 \\
\hline sro & 0.38 & $\mathrm{Nd}_{2} \mathrm{O}_{3}$ & 1.67 \\
\hline $\mathrm{Y}_{2} \mathrm{O}_{3}$ & 0.21 & $\mathrm{Sm}_{2} \mathrm{O}_{3}$ & 0.33 \\
\hline $\mathrm{ZrO}_{2}$ & 1.77 & $\mathrm{Eu}_{2} \mathrm{O}_{3}$ & 0.07 \\
\hline $\mathrm{MoO}_{3}$ & 2.28 & $\mathrm{Gd}_{2} \mathrm{O}_{3}$ & 0.05 \\
\hline $\mathrm{RuO}_{2}$ & 1.07 & $\mathrm{U}_{3} \mathrm{O}_{8}$ & 4.58 \\
\hline $\mathrm{Rh}_{2} \mathrm{O}_{3}$ & 0.17 & $\mathrm{Fe}_{2} \mathrm{O}_{3}$ & 9.77 \\
\hline Pdo & 0.53 & $\mathrm{Cr}_{2} \mathrm{O}_{3}$ & 0.41 \\
\hline $\mathrm{Ag}_{2} \mathrm{O}$ & 0.03 & $\mathrm{NiO}$ & 0.20 \\
\hline Cdo & 0.03 & $\mathrm{P}_{2} \mathrm{O}_{5}$ & 0.48 \\
\hline $\mathrm{TeO}_{2}$ & 0.26 & $\mathrm{Na}_{2} \mathrm{O}$ & 12.51 \\
\hline $\mathrm{Cs}_{2} \mathrm{O}$ & 1.03 & $\mathrm{SiO}_{2}$ & 39.80 \\
\hline $\mathrm{BaO}$ & 0.56 & $\mathrm{~B}_{2} \mathrm{O}_{3}$ & 9.47 \\
\hline $\mathrm{La}_{2} \mathrm{O}_{3}$ & 0.53 & $\mathrm{CaO}$ & 2.00 \\
\hline $\mathrm{CeO}_{2}$ & 1.19 & $\mathrm{ZnO}$ & 4.97 \\
\hline $\mathrm{TiO}_{2}$ & 2.97 & & \\
\hline
\end{tabular}

$\left(\mathrm{K}_{2} \mathrm{Ca}_{2} \mathrm{Mg}\left(\mathrm{SO}_{4}\right)_{2} 2 \mathrm{H}_{2} \mathrm{O}\right)$. Trace amounts of clay appearing material were observed in dissolved salt samples, but these have not been characterized. Because bedded salts are stratified chemical precipitates, their composition can be highly variable over distances of a few centimeters. The material used for the waste package tests was from a $15 \mathrm{~cm}$ diameter core about $30 \mathrm{~cm}$ high. It was red-brown in color, probably due to small hematite inclusions and the presence of polyhalite.

A11 three rock materials were crushed manualiy then ground in an agate or tungsten carbide disc mill to pass a 200 mesh $(75 \mu \mathrm{m})$ sieve. The composition of the granite and basalt powders was determined by fusion in $\mathrm{NaOH}$ and $\mathrm{KOH}$ followed by dissolution and analys is by ICP (Inductively Coupled Plasma) spectroscopy. A United States Geological Survey standard (granite-G2) and a basalt standard (ARHCO-1) were also analyzed by this method. The results of both the standard analyses, the Climax Stock Granite, and Umtanum Basalt are shown in Tables 2 and 3 . The results of the standard rock materials are 
TABLE 2. Comparison of ICP Analyses of Granite and Basalt Standards With Accepted Values.

USGS GRANITE G2

$\frac{\text { ICP Analysis }}{64.0} \quad \frac{\text { Accepted (a) }}{69.1}$

0.46

13.5

2.7

$\mathrm{N} / \mathrm{A}$

0.5

0.76

2.0

5.4

3.88

0.32
0.5

15.4

1.08

1.45

0.034

0.76

1.94

4.07

4.55

0.14

\begin{tabular}{cc} 
ARHCO 1 & BASALT \\
\hline $\begin{array}{c}\text { Values Reported (b) } \\
\text { ICP Analysis }\end{array}$ & $\frac{52-5 A-93}{\text { RHo- }}$ \\
\cline { 2 - 2 } 50.3 & 52.5 \\
2.6 & 2.76 \\
12.3 & 13.79 \\
13.6 & 13.73 \\
N/A & N/A
\end{tabular}

0.26

0.19

2.95

6.40

5.9

3.20

3.6

2.52

2.4

0.90

(a) Flanagan (1973)

(b) Additon and Seil (1979)

(c) $\mathrm{N} / \mathrm{A}=$ Not analyzed.

compared with accepted values in Table 2 and indicate that the analyses are satisfactory although $\mathrm{SiO}_{2}$ may be somewhat low. Powders obtained from crushing the bedded salt were dissolved and analyzed by ICP. A partial analysis (chlorine and sulfur were not determined) of the salt is shown in Table 3. The elemental percent of $\mathrm{Na}$, expressed as $\mathrm{NaCl}$, yields values between 82 and 89 percent $\mathrm{NaCl}$ which is consistant with Lambert's (1980) results.

Circular wafers about $6 \mathrm{~mm}$ thick and $19 \mathrm{~mm}$ in diameter were cut from diamond drilled cores of the original granite and basalt rock samples with a silicon carbide cutoff saw. Square or round wafers about the same size were also cut from the salt material. The granite and basalt wafers were polished lightly and cleaned in alcohol and acetone. These rock wafers were included in the package assembly so that samples for surface anays is would be available. An example of these wafers along with samples of the crushed rock matrix material is shown in Figure 1. 
TABLE 3. Bulk Compositions of Granite and Basalt Used in Waste Package Tests Wt \%

\begin{tabular}{|c|c|c|c|}
\hline & $\begin{array}{c}\text { Climax Stock } \\
\text { Granite }\end{array}$ & Umtanum Basalt & \\
\hline $\mathrm{SiO}_{2}$ & 66.3 & 53.5 & \\
\hline $\mathrm{TiO}_{2}$ & 0.4 & 2.1 & \\
\hline $\mathrm{Al}_{2} \mathrm{O}_{3}$ & 14.6 & 12.4 & \\
\hline $\mathrm{Fe}_{2} \mathrm{O}_{3}$ & 2.9 & 13.5 & \\
\hline $\mathrm{FeO}$ & $N / A$ & $N / A$ & $N / A=$ Not Analyzed \\
\hline $\mathrm{MnO}_{2}$ & 0.07 & 0.27 & \\
\hline $\mathrm{MgO}$ & 0.78 & 3.2 & \\
\hline $\mathrm{CaO}$ & 3.58 & 6.9 & \\
\hline $\mathrm{Na}_{2} \mathrm{O}$ & 3.9 & 3.5 & \\
\hline $\mathrm{K}_{2} 0$ & 3.2 & 1.5 & \\
\hline $\mathrm{P}_{2} \mathrm{O}_{5}$ & 0.57 & 0.9 & \\
\hline Sro & 0.07 & 0.04 & \\
\hline $\mathrm{MoO}_{2}$ & 0.02 & 0.07 & \\
\hline $\mathrm{ZnO}$ & 0.02 & 0.04 & \\
\hline $\mathrm{BaO}$ & 0.07 & 0.08 & \\
\hline
\end{tabular}

PARTIAL ANALYSIS OF S.E. NEW MEXICO SALT

Wt. Percent Element

$\begin{array}{ll}\mathrm{Na} & 32.1-35.1 \text { (As } \mathrm{NaCl}=81.6 \text { to } 89.2 \text { percent) } \\ \mathrm{K} & 1.2 \\ \mathrm{Ca} & 0.7 \\ \mathrm{Mg} & 0.2 \\ \mathrm{Fe} & 0.003 \\ \mathrm{Sr} & 0.013 \\ \mathrm{Sb} & 0.02 \\ \mathrm{La} & 0.005 \\ \mathrm{~B} & 0.003 \\ \mathrm{Si} & 0.003 \\ \mathrm{Zn} & 0.001\end{array}$




\section{TEST PACKAGE ASSEMBLY}

A schematic diagram of the test package assembly is shown in Figure 2. The size of the package was dictated by the size of the pressure vessels available for hydrothermal experimentation. The available vessels were Teflon*-lined acid digestion bombs with about $125 \mathrm{ml}$ capacity and direct sampling autoclaves of about $850 \mathrm{ml}$ capacity. Although the digestion bombs had a sma 11 capacity they were simple to operate and could be quenched by submersion in an attempt to avoid cool-down reactions. They also permitted a comparison of results with the direct sampling autoclaves. The package configuration shown in Figure 2 was used in the large autoclaves using minicanisters up to $50 \mathrm{~mm}$ long and a smaller version, eliminating the glass wafer, and using a minicanister about $25 \mathrm{~mm}$ long, was used in the digestion bombs. A photograph of the digestion bomb is shown in Figure 3 along with the package components, and a direct sampling autoclave similar to those used is shown in Figure 4 . A more detailed description of these autoclaves is given by Bradley et al. 1980. The hydrothermal experiments conducted in the digestion bombs permitted a solution to package mass ratio of about 0.5 and those in the $850 \mathrm{ml}$ autoclaves allowed a ratio of about 3.0. The masses of individual components of the digestion bomb runs and autoclave runs are given in Table 4. The mass ratio of glass to metal in the minicanister is 2.1 so that in general the mass of glass amounts to 20 percent or less of the solid components of the waste package.

\section{TEST OPERATION}

A preliminary test at $250^{\circ} \mathrm{C} / 2000$ psig for 30 days using a $75 \mathrm{~mm}$ canister in a granite matrix was conducted in a 3.8 liter autoclave before either the digestion bombs or the direct sampling autoclaves were available. Unfortunately a slow leak developed and most of the solution was lost while the package was exposed to a vapor phase for most of the run duration instead of remaining submersed. Surface analys is from both the glass and rock pellet from this test is reported later. The digestion bomb liner containing a minicanister with a rock wafer resting on the exposed glass surface was loosely

\footnotetext{
*Teflon is a registered trademark of the DuPont Co.
} 


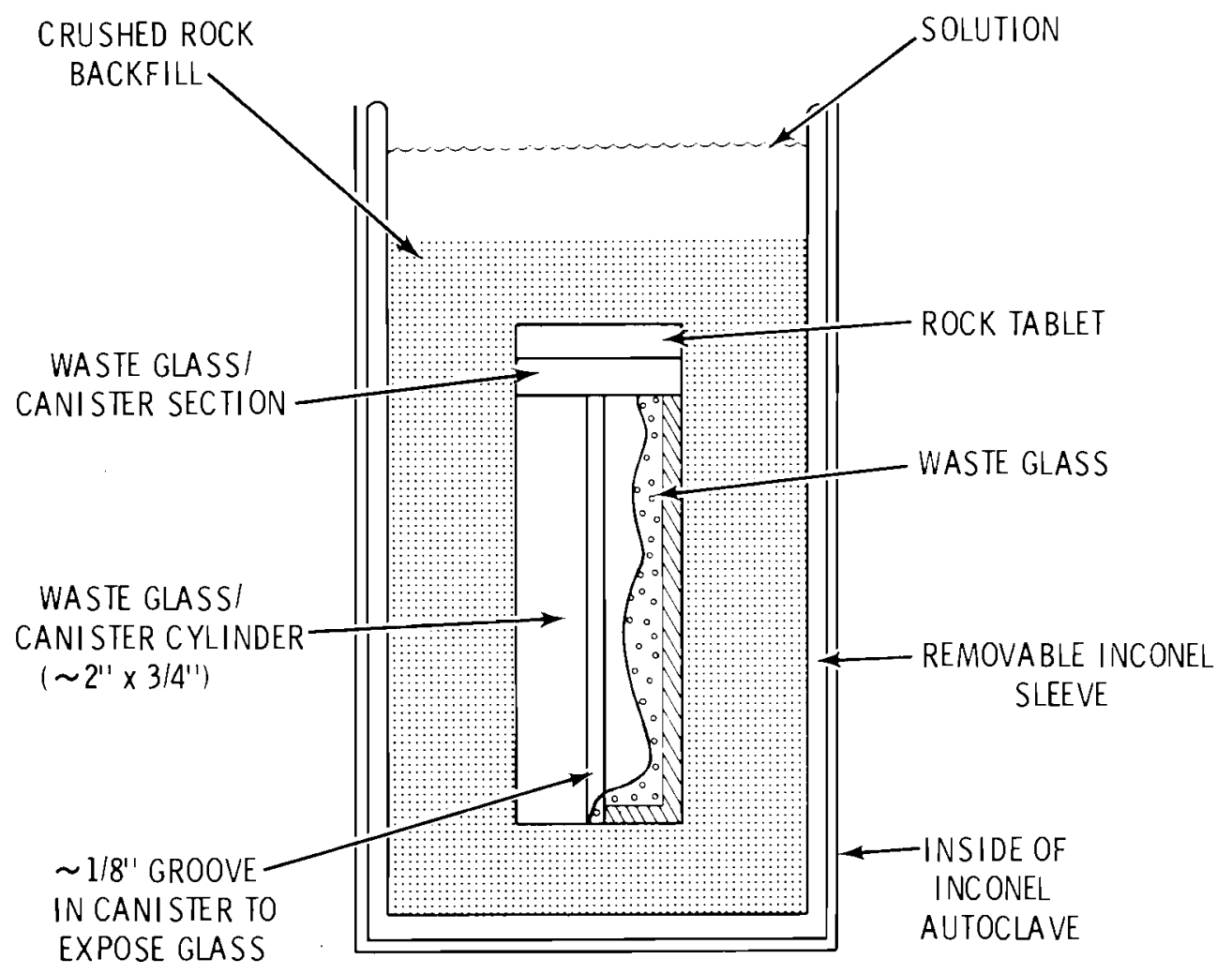

FIGURE 2. Schematic of Test Package Assembly Used in Autoclave Tests

packed with rock powder so that the powder covered both the canister and rock wafer. Fifty $\mathrm{ml}$ of deionized (DI) water were added to the basalt and granite components and a salt brine was added to the salt package. The salt brine was prepared by saturating distilled, deionized water with crushed, bedded salt at about $50^{\circ} \mathrm{C}$. The vessels were then sealed and placed in a laboratory oven at either $250^{\circ} \mathrm{C}$ or $150^{\circ} \mathrm{C}$. These vessels did not have the capability for direct thermocouple insertion, so they were clustered around a central thermocouple in the oven. This thermocouple was monitored during the run and generally remained with $\pm 10^{\circ} \mathrm{C}$ of the set point. Note that in these runs, the pressure was the vapor pressure of the solution which at $250^{\circ} \mathrm{C}$ for water is 600 psig. The only metallic constituent exposed to the package was the stainless steel canister. At the end of these runs, the vessels were quenched by submersing them in a water bath and they were opened within about 5 min after quenching. The $\mathrm{pH}$ of the solutions was measured immediately, then the solutions were pipetted from the liner, acidified to about $\mathrm{pH} 3$ with ultrapure nitric acid 


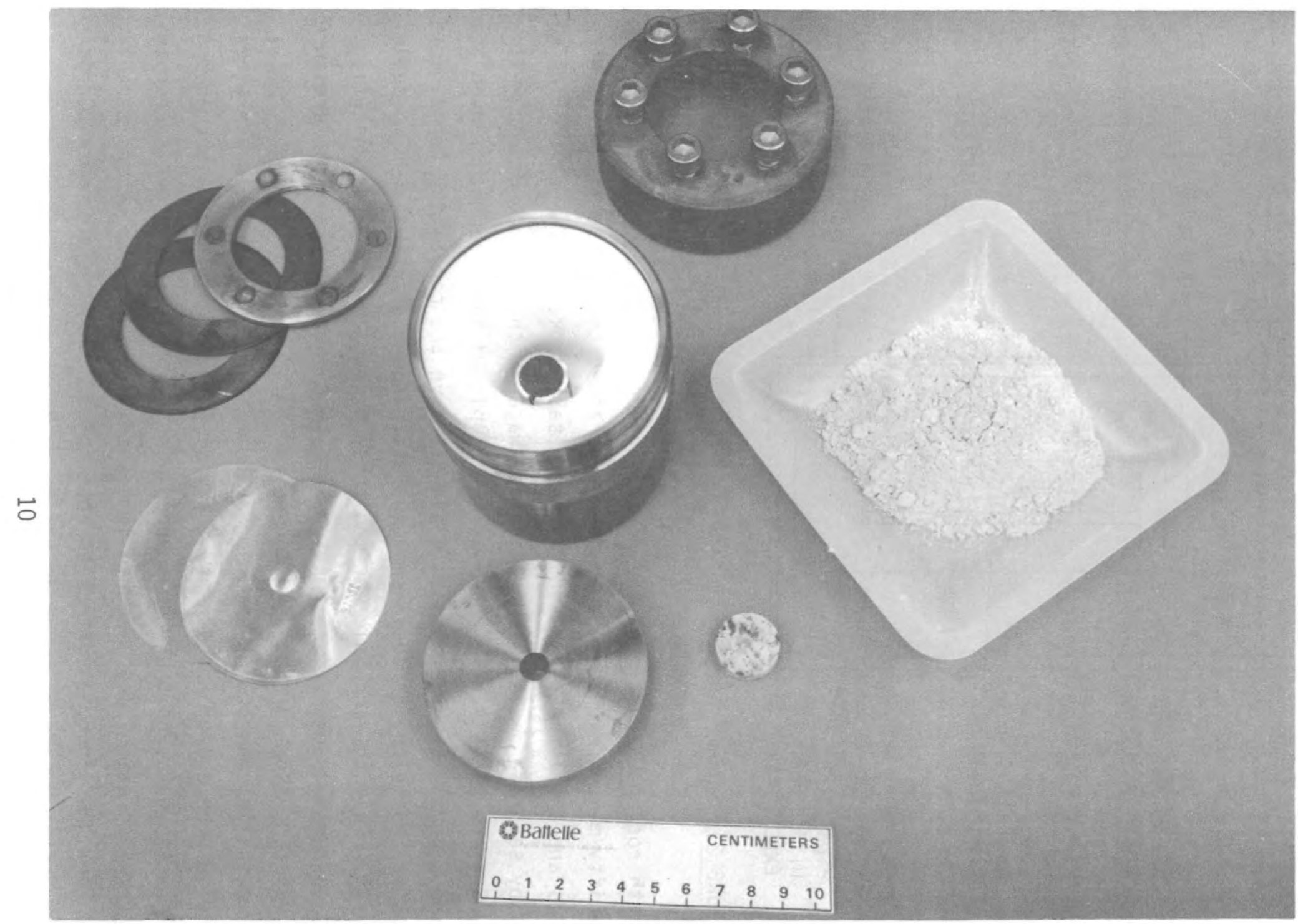

FIGURE 3. $125 \mathrm{ml}$ Digestion Bomb Used in Waste Package Tests 


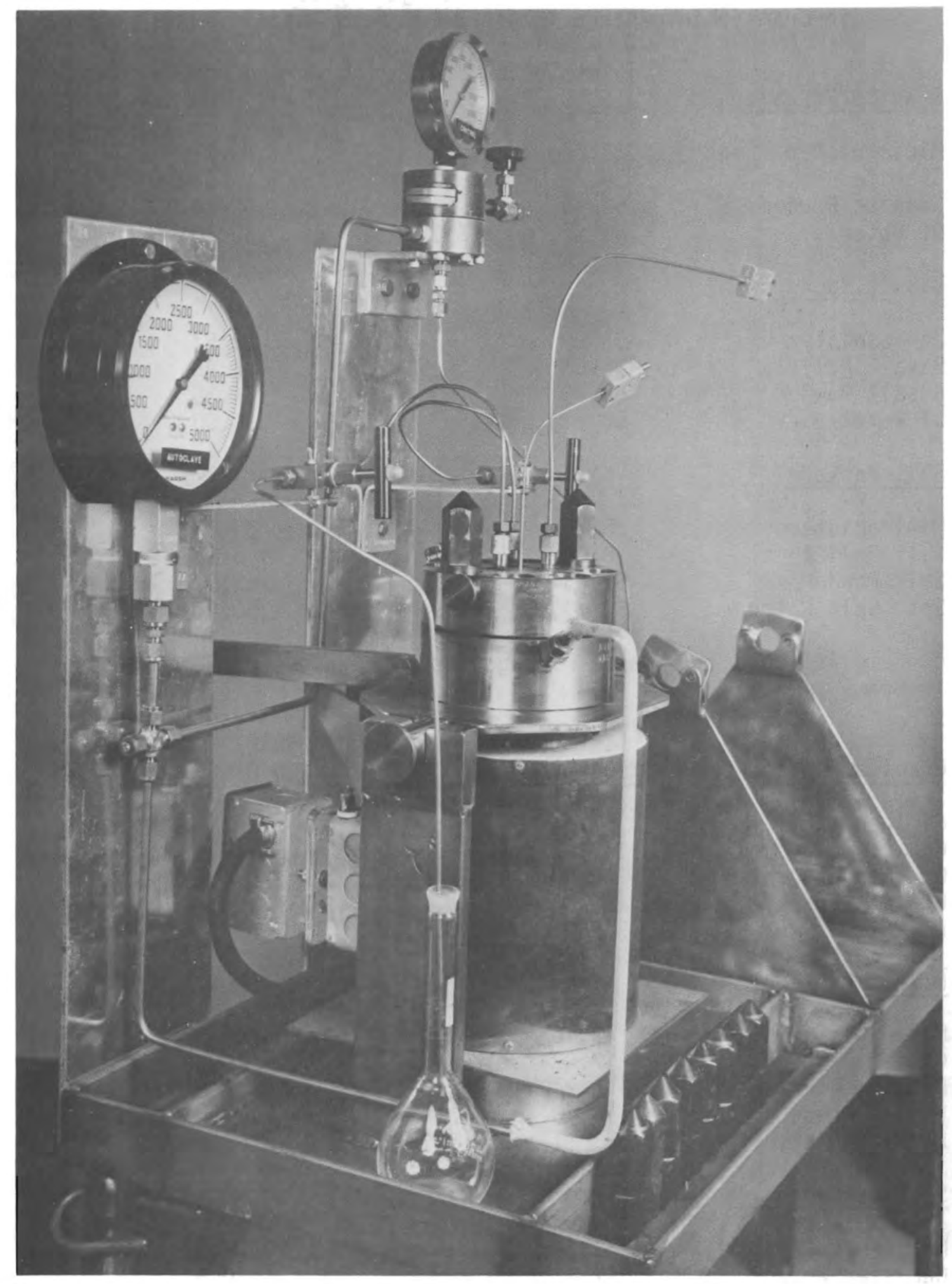

FIGURE 4. Direct Sampling Autoclave Used in Waste Package Tests 
TABLE 4. Teflon Digestion Bomb Waste Package Tests. Masses of Components are in Grams (Minicanister Glass/Metal Mass Ratio $=2.1$ )

\begin{tabular}{llc} 
Granite Package & \multicolumn{1}{c}{$\begin{array}{l}\text { 1st Series } \\
250^{\circ} \mathrm{C} / 30 \text { days }\end{array}$} & $\begin{array}{c}\text { 2nd Series } \\
150^{\circ} \mathrm{C} / 60 \text { days }\end{array}$ \\
\cline { 3 - 4 } Minicanister & 32.63 & \\
Granite Pellet & 6.38 & 33.51 \\
Granite Powder & 54.46 & 5.68 \\
DI Water & $50 \mathrm{ml}, \mathrm{pH}=5.7$ & 50.74 \\
D & &
\end{tabular}

Basalt Package

Minicanister

33.96

6.81

32.57

Basalt Pellet

68.36

5.95

Basalt Powder

$50 \mathrm{ml}, \mathrm{pH}=5.7$

69.36

DI Water

50.00

Salt Package

Minicanister

Salt Pellet

35.25

35.00

8.09

5.27

Salt Powder

67.65

68.00

Sat. Salt Water

$50 \mathrm{ml}, \mathrm{pH}=5.5$

50.00

Direct Sampling Autoclave Waste Package Tests. Masses of Components are in Grams

Granite Package

Minicanister

Canister Wafer

Granite Wafer

Granite Powder

DI Water

Basalt Package

Minicanister

Canister Wafer

Basalt Wafer

Basalt Powder

DI Water

Salt Package

Minicanister

Canister Wafer

Salt Wafer

Salt Powder

Brine Solution 1st Series $250^{\circ} \mathrm{C} / 2000 \mathrm{psig}$

50.15

12.45

6.50

122.47

$575 \mathrm{ml}, \mathrm{pH}=5.7$

49.40

12.93

6.74

136.78

$575 \mathrm{ml}, \mathrm{pH}=5.7$

2nd Series

$250^{\circ} \mathrm{C} / 2000 \mathrm{psig} / 3 \mathrm{wk}$

$250^{\circ} \mathrm{C} / 1000 \mathrm{psig} / 1 \mathrm{wk}$

51.11

9.67

6.19

123.88

$575 \mathrm{ml}, \mathrm{pH}=5.7$

49.22

11.36

5.99

121.42

$575 \mathrm{ml}, \mathrm{pH}=5.7$
50.54

12.43

7.03

121.91

$575 \mathrm{ml}, \mathrm{pH}=5.5$
49.32

10.52

7.68

117.39

$575 \mathrm{ml}, \mathrm{pH}=5.5$ 
and analyzed by ICP spectroscopy. The packages were then dissassembled for analysis of the solid components. The rock wafers were removed and not cleaned so that they could be used for X-ray Photoelectron Spectroscopy (XPS) and Scanning Electron Microscopy (SEM) analysis. The powders were sampled with respect to the top, bottom, and slit of the minicanister and stored. At the present time, X-ray Diffraction (XRD) and SEM analys is of these powders has just been started.

Figure 5 is a photograph of the first digestion bomb waste packages immediately after the vessels were opened and the solution extracted. Note the extensive recrystallization of the salt. Figure 6 is a photograph of the components of the granite and salt package and aga in shows the extensive recrystallization of the salt. The salt wafers in these packages was recrystallized to the extent they had to be chipped out.

The packages for the direct sampling, $850 \mathrm{ml}$ autoclaves were assembled in a stainless steel liner which loosely fit into the autoclave chamber. After the package was placed in the autoclave, $575 \mathrm{ml}$ of DI water or salt brine was added. This was about the maximum amount of solution that could be added. Compared with the digestion bomb tests, considerably more metal was exposed to the package from the canister and liner material (stainless steel, 304L) and inconel from the autoclave body. These autocalves were pressurized with argon gas by allowing it to flow directly into the autoclave. The total pressure was maintained at 2000 psig throughout the heating and testing periods. It is expected that the redox conditions generated in these tests were more reducing than in the digestion bomb tests, although no attempt to measure the redox potential was made. The heating jacket for these autoclaves does not enclose the head so that the probability of fluid convection during a run is high. Also note that the vapor phase is a mixture of argon saturated with water vapor. One effect of this vapor phase composition is to reduce the chemical potential of the $\mathrm{H}_{2} \mathrm{O}$ component in the vapor relative to a pure water vapor phase at the same total pressure (Greenwood 1961). Consequently the liquid part of the system is in equilibrium with water vapor at a pressure lower than the total pressure. This may be an important consideration when comparing results of direct sampling autoclave tests with gold capsule hydrothermal experiments. 


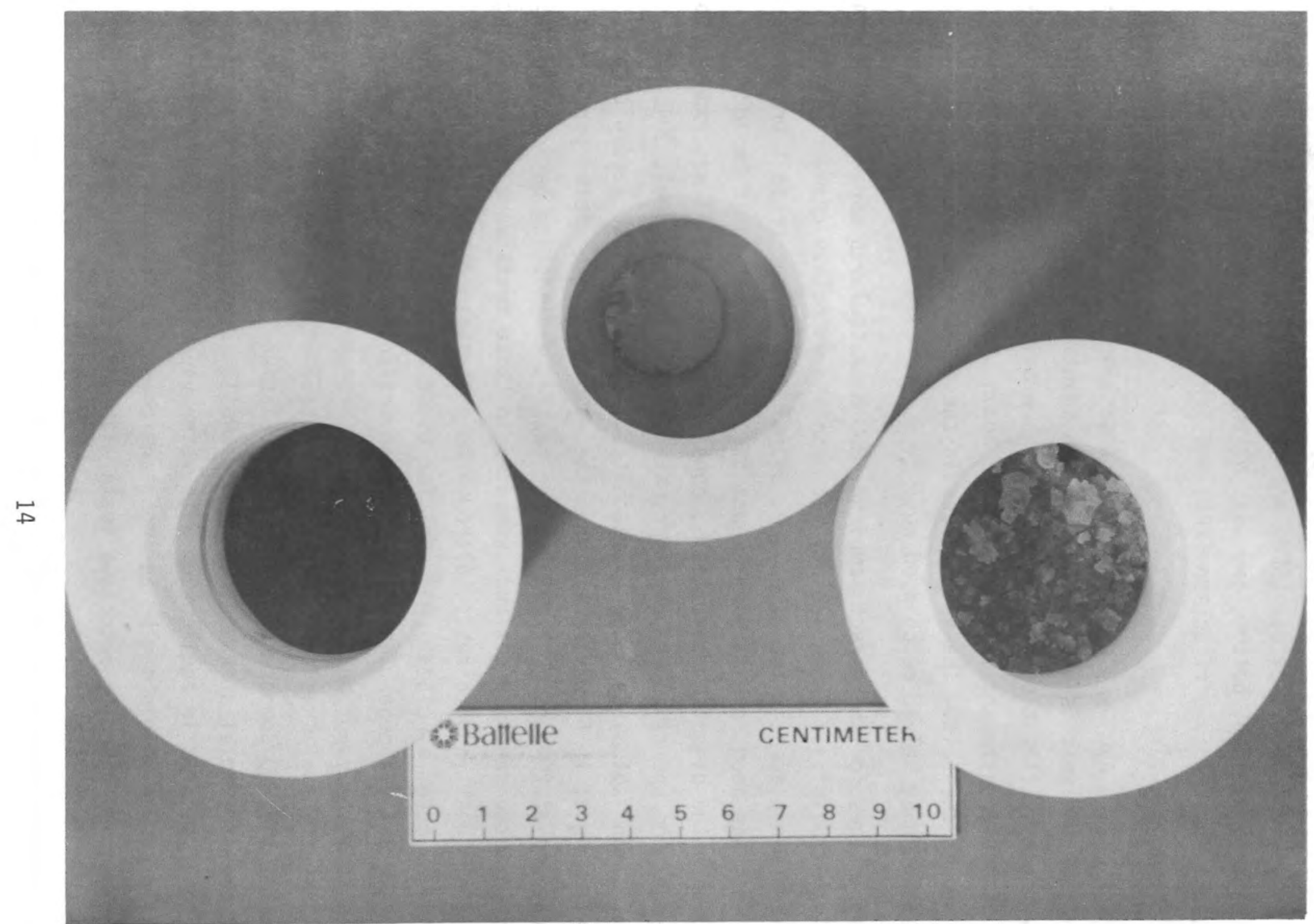

FIGURE 5. Digestion Bomb Packages Immediately After $250^{\circ} \mathrm{C}, 30$ Day Run Left $=$ Basalt, Center $=$ Granite, Right $=$ Salt 

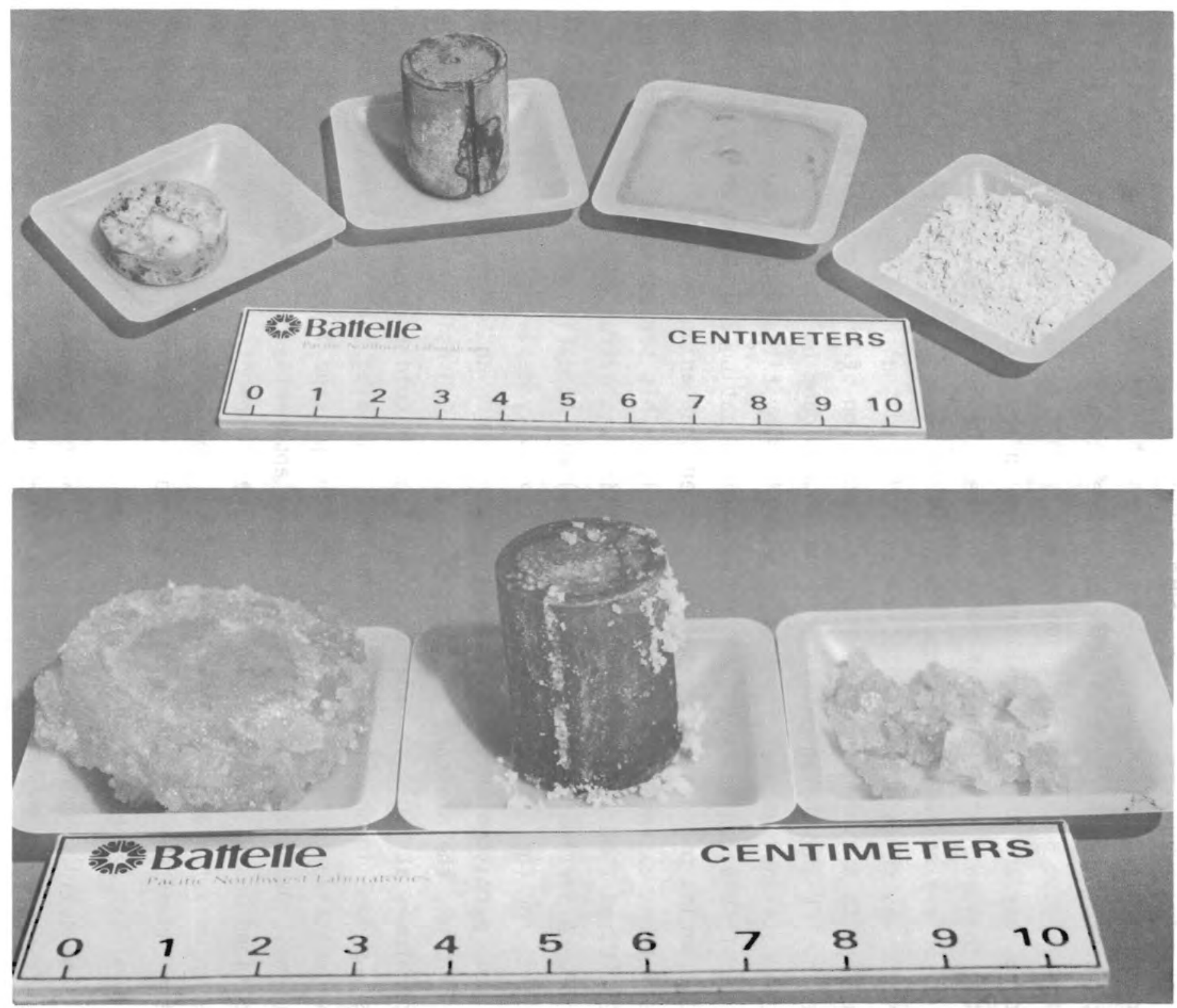

FIGURE 6. Components of Granite and Salt Packages Immediately After Run 
Two series of runs were conducted in these autoclaves and a third series is currently in progress. For the first series, the autoclaves were operated at $250^{\circ} \mathrm{C}$ and 2000 psig total pressure for $4 \mathrm{wk}$. About $5 \mathrm{ml}$ of solution was extracted into $20 \mathrm{ml}$ of DI water as soon as the autoclave reached pressure and temperature. Similar extractions were made at weekly intervals for the 4 wk period. These solutions were analyzed for their cation concentration by ICP spectroscopy and the total solution volume in the autoclave was not significantly changed. At the end of the run time, the heater was switched off and the autoclave was allowed to cool down over a period of several hours. The pressure was released, the autoclave opened, and the remaining solution was removed with a syringe. The cation concentration of this solution was determined by ICP and the anions in this cooldown liquor by ion chromatography. Bicarbonate and carbonate ions were determined by titration. About 80 to $100 \mathrm{ml}$ of solution was required for a complete cation and anion analysis so a second series of runs was conducted in order that anion analyses could be made on solutions extracted at periodic intervals. This series was also operated at $250^{\circ} \mathrm{C}$ and 2000 psig but $100 \mathrm{ml}$ of solution was extracted at each sampling period. A portion of this solution $(20 \mathrm{ml}$ ) was acidified to $\mathrm{pH} 3$ (and not diluted) for the cation analysis. This obviously depleted the solution volume, but permitted enough solution for both cation and anion analysis. At the end of $3 \mathrm{wk}$, the pressure was dropped to about 1000 psig while maintaining the temperatures at $250^{\circ} \mathrm{C}$ in order to convert all liquid to vapor in the system. This was done in an attempt to create more oxidizing conditions in the autoclave relative to those which exist when the package is emersed in liquid solution. Oxidation and uranium transport apparently occurs under such vapor conditions based on observations of package components from a preliminary run made in an autoclave that developed a slow leak during a 30 day run period. At the end of the run, the autoclave was cooled as previously described, and the cooldown liquor was submitted for both cation and anion analysis.

The solid components of the packages were removed as described previously except that considerable difficulty was encountered in removing the salt package from the second series because of extensive salt recrystallization. Because of precipitation problems in the sampling tube, only one salt solution sample could be obtained. 


\section{RESULTS OF SOLUTION ANALYSIS}

The compositions of solutions extracted from the digestion bomb and direct sampling autoclaves are presented in Tables 5 thru 12. Analytical results of brines from the salt package tests will be described first, followed by the results of solutions from the granite and basalt package tests.

Table 5 lists brine compositions from digestion bomb tests at $250^{\circ} \mathrm{C}$ and $150^{\circ} \mathrm{C}$ for 4 and 6 wk respectively. Because of the small solution volume, anion data were not obtained. It is apparent from these data that significant solution composition changes occur as a result of salt recrystallization in the closed system during the run. When recalculated in terms of weight percent $\mathrm{NaCl}$, the percentage of $\mathrm{NaCl}$ from Table 5 varies from 23 to 26 weight percent of room temperature. This is consistant with the $\mathrm{NaCl}$ solubility data along the three-phase boundary (vapor-liquid-NaCl) shown in Figure 7 (Holland and Malinin 1979). Figure 7 also shows that $\mathrm{NaCl}$ solubilty can increase to 33-35 weight percent at $250^{\circ} \mathrm{C}$. The increase in salt solubility during the run leads to recrystallization and precipitation during the cooldown period. The result is that some elements become repartitioned between the solid salt and liquid phases. Comparison of initial with final brine composition in Table 5 shows the extent of some of is repartitioning. As an example, $\mathrm{Mg}$ becomes more concentrated in the liquid phase, as would be expected on the basis of salt fluid inclusion compositions, and $\mathrm{Ca}$ and $\mathrm{Sr}$ become more concentrated in the recrystallized salt. In addition the effects of corrosion on both the glass and canister are apparent. For example $\mathrm{Cs}, \mathrm{Zn}$, and $\mathrm{Ni}$ show increased liquid phase concentrations. Note also that the final pH of the solutions has dropped, possibily as the result of $\mathrm{HCl}$ and $\mathrm{H}_{2} \mathrm{SO}_{4}$ formation.

Table 6 shows similar data from the $850 \mathrm{ml}$ direct sampling autoclave runs along with anion concentrations from the cooldown liquid. In general, the same effects are apparent as in the digestion bomb tests, but the magnitudes have been modified, probably because of the different sample configuration and larger solution volume.

Solution compositions from the basalt and granite digestion bomb runs at $250^{\circ} \mathrm{C}$ and $150^{\circ} \mathrm{C}$ are given in Table 7 . It is apparent from these data that 
TABLE 5. Composition of Brines from Teflon Digestion Bomb Tests $\mu \mathrm{g} / \mathrm{ml}$

\begin{tabular}{|c|c|c|c|c|}
\hline Element & $\begin{array}{c}\text { Initial } \\
\text { Brinet }\end{array}$ & $250^{\circ} \mathrm{C} / 4 \mathrm{wk}$ & $150^{\circ} \mathrm{C} / 6 \mathrm{wk}$ & $\begin{array}{l}\text { Detection } \\
\text { Limits (ICP) }\end{array}$ \\
\hline$=\frac{\mathrm{Si}}{\mathrm{Si}}$ & $\frac{2.6^{\star}}{2}$ & $\frac{1906 / 4.64}{19.6}$ & $\frac{100.000}{59.0}$ & $\frac{0.005}{0}$ \\
\hline Al & $1.3^{\star}$ & 3.3 & 4.8 & 0.013 \\
\hline $\mathrm{Fe}$ & $0.1 *$ & 6.0 & 1.3 & 0.003 \\
\hline $\mathrm{Mg}$ & 464.5 & 4084.0 & 2940.0 & 0.005 \\
\hline$M n$ & D.L. & 5.2 & 2.5 & 0.001 \\
\hline $\mathrm{Ca}$ & 971.0 & 156.6 & 171.0 & 0.005 \\
\hline $\mathrm{Na}$ & 90737.0 & 87050.0 & 103850.0 & 0.17 \\
\hline K & 1562.0 & 11910.0 & 10600.0 & 0.041 \\
\hline $\mathrm{Ti}$ & D.L. & 0.22 & 0.2 & 0.001 \\
\hline $\mathrm{P}$ & D.L. & 11.42 & 17.8 & 0.047 \\
\hline $\mathrm{Cr}$ & D.L. & 1.22 & 3.05 & 0.006 \\
\hline $\mathrm{Ni}$ & D.L. & 11.77 & 1.8 & 0.007 \\
\hline Cs & 0.97 & 16.0 & 22.0 & 0.10 \\
\hline $\mathrm{Sr}$ & 24.0 & 12.83 & 11.05 & 0.001 \\
\hline$B a$ & $0.25 *$ & 1.87 & 1.60 & 0.001 \\
\hline Li & $0.72^{\star}$ & 0.71 & 1.35 & 0.002 \\
\hline B & $1.00^{*}$ & 73.9 & 58.5 & 0.004 \\
\hline Mo & D.L. & 1.97 & 9.80 & 0.003 \\
\hline $\mathrm{Pb}$ & 0.5 & 10.58 & 8.0 & 0.009 \\
\hline Ru & $1.4^{*}$ & 3.19 & 4.4 & 0.007 \\
\hline Te & 1.2* & 7.76 & 4.25 & 0.02 \\
\hline $\mathrm{Gd}$ & $1.5^{\star}$ & 1.56 & 2.5 & 0.004 \\
\hline La & 6.2 & 1.14 & 1.2 & 0.02 \\
\hline Dy & $0.1^{*}$ & 0.87 & 0.5 & 0.001 \\
\hline Eu & D.L. & 0.3 & 0.15 & 0.001 \\
\hline Sb & $0.7^{\star}$ & 3.59 & D.L. & 0.015 \\
\hline $\mathrm{In}$ & D.L.* & 29.51 & 56.0 & 0.004 \\
\hline Co & $0.1^{*}$ & 1.06 & 0.85 & 0.002 \\
\hline $\mathrm{Cd}$ & $0.1 *$ & 0.3 & 0.35 & 0.002 \\
\hline $\mathrm{Ce}$ & $2.7^{\star}$ & 2.8 & 3.9 & 0.009 \\
\hline U & -- & $15 \mathrm{ppb}$ & -- & -. \\
\hline $\mathrm{pH}$ & 5.8 & 2.4 & 3.9 & -. \\
\hline
\end{tabular}

* Concentrations of these elements were close enough to detection limits of the diluted solutions so that large errors result when multiplied by the dilution factor.

tThese data represent three replicates of two different solutions. Starred compositions have $\pm 50 \%$ error and non-starved compositions $\pm 10 \%$ error. 
TABLE 6. Brine Compositions From $850 \mathrm{ml}$ Direct Sample Autoclave Tests (a) $250^{\circ} \mathrm{C} / 2000 \mathrm{psi}$ Argon, $\mu \mathrm{g} / \mathrm{mi}$

\begin{tabular}{|c|c|c|c|c|}
\hline Element & $\begin{array}{l}\text { Brine Sample } \\
\text { At P\&T }\end{array}$ & $\begin{array}{l}\text { Brine Sample } \\
\text { At } 20^{\circ} \mathrm{C}, 4 \text { wk }\end{array}$ & $\begin{array}{l}\text { Cooldown } \\
\text { Liquor } 6 \text {, wk }\end{array}$ & $\begin{array}{l}\text { Anion Composition } \\
\text { Cooldown Liquor }\end{array}$ \\
\hline Si & 5.1 & 0.0 & 5.4 & $\mathrm{HCO}_{3}^{-}-0.0$ \\
\hline Al & 3.9 & 7.4 & 10.0 & $\mathrm{CO}_{3}^{-}-0.0$ \\
\hline $\mathrm{Fe}$ & 0.3 & 22.0 & 27.0 & \\
\hline $\mathrm{Mg}$ & 528.0 & 797.0 & 887.0 & $\mathrm{Cl}^{-}-185,000$ \\
\hline Mn & 0.3 & 2.2 & 1.0 & $\mathrm{SO}_{4}^{-}-5997$ \\
\hline $\mathrm{Ca}$ & 304.0 & 409.0 & 424.0 & $F^{-}-31.3$ \\
\hline $\mathrm{Na}$ & 119000.0 & 114950.0 & 128600.0 & $\mathrm{PO}_{4}^{-}-1043$ \\
\hline K & 2502.0 & 3460.0 & 3950.0 & $\mathrm{NO}_{3}^{-}-\mathrm{N} . \mathrm{O}$. \\
\hline $\mathrm{Ti}$ & 0.0 & 0.7 & N.D. & $\mathrm{MoO}_{4}^{-}-$N.D. \\
\hline$P$ & 0.5 & 11.7 & 10.0 & \\
\hline $\mathrm{Cr}$ & 0.0 & 1.7 & 1.0 & \\
\hline $\mathrm{Ni}$ & 2.2 & 4.0 & 5.5 & $N / A=$ Not Analyzed \\
\hline Cs & 9.5 & 25.0 & 15.0 & $N D=$ Not Detected \\
\hline$S r$ & 10.0 & 20.1 & 20.0 & \\
\hline $\mathrm{Ba}$ & D.L. & 1.7 & 1.3 & \\
\hline Li & 1.1 & 1.2 & 5.0 & \\
\hline B & 0.0 & 51.6 & 33.0 & \\
\hline Mo & 0.8 & 5.5 & 3.1 & \\
\hline $\mathrm{Pb}$ & 3.5 & 12.2 & 10.0 & \\
\hline Ru & 2.5 & 6.0 & 10.0 & \\
\hline Te & 0.3 & 7.9 & $\mathrm{~N} / \mathrm{A}$ & \\
\hline Gd & 2.3 & 7.7 & $N / A$ & \\
\hline La & 1.7 & 4.5 & $\mathrm{~N} / \mathrm{A}$ & \\
\hline Dy & 0.6 & 2.1 & $\mathrm{~N} / \mathrm{A}$ & \\
\hline Eu & 0.0 & 0.6 & $\mathrm{~N} / \mathrm{A}$ & \\
\hline Sb & 0.7 & 4.2 & 5.0 & \\
\hline $\mathrm{Zn}$ & 6.2 & 9.8 & 10.0 & \\
\hline $\mathrm{Co}$ & 0.9 & 2.1 & 0.3 & \\
\hline $\mathrm{Cd}$ & 0.2 & 0.5 & $\mathrm{~N} / \mathrm{A}$ & \\
\hline $\mathrm{Ce}$ & 5.2 & 11.6 & $\mathrm{~N} / \mathrm{A}$ & \\
\hline $\mathrm{pH}$ & 5.5 & 3.9 & 2.8 & \\
\hline
\end{tabular}


TABLE 7. Solution Compositions from Teflon Digestion Bomb Tests, 30 Days, $\mu \mathrm{g} / \mathrm{m} 1$

\begin{tabular}{|c|c|c|c|c|}
\hline & \multicolumn{2}{|c|}{$250^{\circ} \mathrm{C}$} & \multicolumn{2}{|c|}{$150^{\circ} \mathrm{C}$} \\
\hline & Basalt & Granite & Basalt & Granite \\
\hline Si & 303 & 118.7 & 218 & 93.2 \\
\hline$A 1$ & 3.0 & 3.5 & 0.5 & 0.7 \\
\hline $\mathrm{Fe}$ & 7.6 & 2.0 & 0.03 & 0.1 \\
\hline $\mathrm{Mg}$ & 1.2 & 1.0 & 0.01 & 0.1 \\
\hline$M n$ & 0.01 & 0.07 & D.L. & D.L. \\
\hline $\mathrm{Ca}$ & 1.4 & 20.3 & 4.5 & 11.9 \\
\hline $\mathrm{Na}$ & 227 & 256 & 210 & 228 \\
\hline K & 53.2 & 14.3 & 70.1 & 6.1 \\
\hline $\mathrm{Ti}$ & 0.16 & 0.2 & D.L. & 0.0 \\
\hline$P$ & 0.6 & 0.2 & 0.07 & 0.04 \\
\hline $\mathrm{Cr}$ & 0.06 & 0.02 & 0.06 & 0.05 \\
\hline $\mathrm{Ni}$ & 0.02 & D.L. & D.L. & D.L. \\
\hline Cs & 0.21 & 6.1 & $N / A$ & $N / A$ \\
\hline Sr & D.L. & 0.10 & 0.02 & 0.07 \\
\hline $\mathrm{Ba}$ & 0.01 & 0.02 & 0.01 & D.L. \\
\hline Li & 0.14 & 0.8 & 0.2 & 0.5 \\
\hline B & 207 & 177 & 66.3 & 98.0 \\
\hline Mo & 58.5 & 14.7 & 27.1 & 35.4 \\
\hline Ru & 0.1 & 0.06 & D.L. & 0.01 \\
\hline Te & D.L. & 0.02 & D.L. & D.L. \\
\hline La & D.L. & 0.04 & 0.02 & 0.07 \\
\hline Sb & 0.5 & 0.2 & 0.4 & $N / A$ \\
\hline $\mathrm{Zn}$ & 0.01 & 0.02 & 1.7 & 0.1 \\
\hline Co & 0.04 & 0.02 & D.L. & D.L. \\
\hline $\mathrm{pH}$ & 7.8 & 8.6 & 7.8 & 8.3 \\
\hline
\end{tabular}


TABLE 8. Composition of Solutions Extracted at $250^{\circ} \mathrm{C} / 2000$ psi from $850 \mathrm{ml}$ Autoclave Runs, $\mu \mathrm{g} / \mathrm{ml}$, (Series 1) Initial Solution DI Water, Umtanum Basalt Package

\begin{tabular}{|c|c|c|c|c|c|}
\hline & $\begin{array}{l}\text { AT } \\
P \& \quad T \\
\end{array}$ & 1 wk & $2 w k$ & $3 w k$ & 4 wk \\
\hline $\mathrm{Si}$ & 58.1 & 140 & 437 & 511 & 515 \\
\hline Al & 5.5 & 6.6 & 5.6 & 4.4 & 4.4 \\
\hline $\mathrm{Fe}$ & 1.6 & 0.2 & 0.6 & 0.3 & 0.3 \\
\hline Mg & 0.3 & 0.1 & 0.03 & 0.06 & 0.3 \\
\hline$M n$ & 0.05 & 0.03 & 0.02 & 0.03 & 0.04 \\
\hline $\mathrm{Ca}$ & 0.9 & 0.3 & 0.5 & 0.3 & 0.4 \\
\hline $\mathrm{Na}$ & 52.6 & 44.5 & 99.5 & 118 & 125 \\
\hline$K$ & 8.1 & 23.6 & 33.8 & 34.0 & 36.6 \\
\hline Ti & 0.1 & 0.03 & 0.09 & 0.04 & 0.04 \\
\hline$P$ & 0.2 & 0.05 & 0.9 & 0.8 & 1.7 \\
\hline $\mathrm{Cr}$ & 0.03 & 0.03 & 0.06 & 0.1 & 0.1 \\
\hline $\mathrm{Ni}$ & 0.1 & 0.5 & 0.4 & 0.1 & 0.1 \\
\hline Cs & 0 & 0.04 & 0.2 & 0.2 & 0.3 \\
\hline Sr & D.L. & D.L. & D.L. & D.L. & D.L. \\
\hline $\mathrm{Ba}$ & D.L. & D.L. & D.L. & D.L. & D.L. \\
\hline Li & 0.01 & 0.01 & 0.05 & 0.09 & 0.09 \\
\hline$B$ & 0 & 25.3 & 64.5 & 100.5 & 126.1 \\
\hline Mo & 0.6 & 8.6 & 34.9 & 56.5 & 72.7 \\
\hline $\mathrm{Ru}$ & D.L. & 0.06 & 0.05 & 0.2 & 0.2 \\
\hline Sb & 0.01 & 0.16 & 0.32 & 0.45 & 0.57 \\
\hline $\mathrm{Zn}$ & 0.17 & 0.5 & 0.3 & 0.3 & 0.4 \\
\hline Co & 0.01 & 0.03 & 0.0 & 0.07 & 0.07 \\
\hline $\mathrm{pH}$ & 6.8 & 7.4 & 7.4 & 7.9 & 7.8 \\
\hline
\end{tabular}


TABLE 9. Composition of Solutions Extracted at $250^{\circ} \mathrm{C} / 2000$ psi from $850 \mathrm{ml}$ Autoclave Runs, $\mu \mathrm{g} / \mathrm{ml}$, (Series I) Initial Solution DI Water, NTS Granite Package

\begin{tabular}{|c|c|c|c|c|c|}
\hline & $P \& T$ & $1 \mathrm{wk}$ & $2 w k$ & $3 w k$ & $4 w k$ \\
\hline Si & 28 & 216 & 217 & 233 & 250 \\
\hline Al & 2.9 & 2.3 & 2.4 & 2.9 & 3.2 \\
\hline $\mathrm{Fe}$ & 0.5 & 0.1 & 0.04 & 0.02 & 0.04 \\
\hline $\mathrm{Mg}$ & 0.2 & 0.2 & 0.2 & 0 & 0 \\
\hline$M n$ & 0.07 & 0.02 & 0.01 & 0.01 & 0.001 \\
\hline $\mathrm{Ca}$ & 0.7 & 0.8 & 0.7 & 0.3 & 0.3 \\
\hline $\mathrm{Na}$ & 37.7 & 88.9 & 66.3 & 80.3 & 112.4 \\
\hline K & 9.9 & 14.5 & 12.3 & 10.5 & 12.1 \\
\hline $\mathrm{Ti}$ & D.L. & D.L. & D.L. & D.L. & D.L. \\
\hline$P$ & D.L. & 0.3 & 0.1 & 0.4 & 0.5 \\
\hline $\mathrm{Cr}$ & 0.07 & 0.02 & 0.02 & 0.02 & 0.04 \\
\hline $\mathrm{Ni}$ & 0.11 & 0.1 & 0.01 & 0.1 & 0.01 \\
\hline Cs & 0.05 & 0.35 & 1.05 & 2.0 & 2.9 \\
\hline Sr & D.L. & D.L. & D.L. & D.L. & D.L. \\
\hline $\mathrm{Ba}$ & D.L. & D.L. & D.L. & D.L. & D.L. \\
\hline Li & 0.05 & 0.3 & 0.3 & 0.3 & 0.3 \\
\hline$B$ & 0.06 & 22 & 41.2 & 63.9 & 91.7 \\
\hline Mo & 0.7 & 2.9 & 5.4 & 9.8 & 17.7 \\
\hline $\mathrm{Ru}$ & D.L. & 0.05 & 0.08 & D.L. & 0.08 \\
\hline $\mathrm{Sb}$ & 0.01 & 0.2 & 0.2 & 0.1 & 0.3 \\
\hline $\mathrm{Zn}$ & 0.1 & 0.3 & 0.3 & 0.3 & 0.4 \\
\hline $\mathrm{pH}$ & 6.9 & 7.6 & 7.6 & 7.9 & 8.5 \\
\hline
\end{tabular}


TABLE 10. Cation-Anion Concentrations of Cooldown Autoclave Liquors From Series I Direct Sampling Autoclave Tests, $\mu \mathrm{g} / \mathrm{ml}$

$\begin{array}{lcc} & \text { Granite } & \text { Basalt } \\ \mathrm{Si} & 193 & 134 \\ \mathrm{Al} & 2.5 & 0.1 \\ \mathrm{Na} & 103 & 139 \\ \mathrm{~K} & 10.9 & 17 \\ \mathrm{Cs} & 2.8 & 0.09 \\ \mathrm{Fe} & 0.3 & 0.1 \\ \mathrm{Mg} & 0.15 & 0.0 \\ \mathrm{Ca} & 4.6 & 0.5 \\ \mathrm{Sr} & 0.01 & 0.0 \\ \mathrm{~B} & 82.8 & 117.3 \\ \mathrm{Ni} & 0.1 & 0.8 \\ \mathrm{Zn} & 0.04 & 0.02 \\ \mathrm{Li}^{-} & 0.3 & 0.1 \\ & & \\ \mathrm{pH}^{-} & 8.5 & 8.2 \\ \mathrm{HCO}_{3}^{-} & 204.8 & 133.1 \\ \mathrm{CO}_{3}^{-} & 1.2 & 0.0 \\ \mathrm{SO}_{4}^{-} & 21.6 & 45.8 \\ \mathrm{~F}^{-} & 9.5 & 28.3 \\ \mathrm{NO}_{3}^{-} & 1.2 & 0.2 \\ \mathrm{PO}_{4}^{-} & 5.4 & 7.0 \\ \mathrm{Cl}^{-} & 4.0 & 25.4 \\ \mathrm{MoO}_{4} & 27.6 & 115 \\ & & \end{array}$


TABLE 11. Solution Composition from Series 2 Direct Sampling Autoclave Runs Granite Matrix, $\mu \mathrm{g} / \mathrm{ml}, 250^{\circ} \mathrm{C} / 2000 \mathrm{psi}$

\begin{tabular}{|c|c|c|c|c|}
\hline$P \& T$ & 1 wk & $2 w k$ & $3 w k$ & $\begin{array}{l}\text { Post Run } \\
\text { Liquor }\end{array}$ \\
\hline 25.6 & 218.0 & 229.0 & 191.0 & 92.6 \\
\hline 4.0 & 2.2 & 2.9 & 3.1 & 6.8 \\
\hline 0.04 & 0.03 & 0.04 & 0.07 & 0.2 \\
\hline D.L. & D.L. & D.L. & D.L. & 0.2 \\
\hline D.L. & D.L. & D.L. & D.L. & 0.03 \\
\hline 0.8 & 1.2 & 0.7 & 0.5 & 0.9 \\
\hline 8.1 & 34.6 & 68.6 & 108.0 & 152.0 \\
\hline 8.0 & 14.2 & 14.7 & 12.7 & 13.4 \\
\hline D.L. & D.L. & D.L. & D.L. & 0.01 \\
\hline 0.06 & 0.08 & 0.1 & 0.2 & D.L. \\
\hline 0.01 & 0.03 & 0.03 & 0.04 & 0.4 \\
\hline 0.02 & 0.01 & 0.04 & 0.05 & 6.7 \\
\hline 0.04 & 0.26 & 0.83 & 1.4 & 1.4 \\
\hline 0.01 & 0.01 & D.L. & D.L. & 0.02 \\
\hline D.L. & D.L. & D.L. & D.L. & 0.06 \\
\hline 0.04 & 0.28 & 0.4 & 0.2 & 0.06 \\
\hline 0.15 & 25.2 & 67.6 & 121.0 & 203.0 \\
\hline 0.39 & 4.1 & 9.8 & 18.0 & 63.4 \\
\hline D.L. & 0.02 & 0.02 & 0.01 & 0.06 \\
\hline 0.01 & D.L. & 0.13 & 0.2 & 0.4 \\
\hline 0.25 & 0.12 & 0.16 & 0.2 & 0.06 \\
\hline 7.0 & 7.7 & 8.3 & 8.4 & 7.9 \\
\hline $\mathrm{HCO}_{3}$ & 65.5 & 125.5 & 192.0 & 265.0 \\
\hline $\mathrm{CO}_{3}$ & 0.0 & 0.0 & 0.0 & 0.0 \\
\hline $\mathrm{SO}_{4}$ & 14.8 & 28.6 & 25.4 & 40.0 \\
\hline$F^{-7}$ & 4.2 & 7.4 & 10.4 & 10.8 \\
\hline $\mathrm{NO}_{3}$ & 1.4 & 1.0 & 0.3 & 0.5 \\
\hline $\mathrm{PO}_{4}$ & 0.5 & 0.2 & 2.9 & 8.8 \\
\hline $\mathrm{Cl}^{-}$ & 5.8 & 5.9 & 6.3 & 5.1 \\
\hline $\mathrm{MoO}_{4}$ & 5.2 & 14.0 & 27.3 & 84.6 \\
\hline
\end{tabular}


TABLE 12. Solution Composition from Series 2 Direct Sampling Autoclave Runs Basalt Matrix, $\mu \mathrm{g} / \mathrm{ml}, 250^{\circ} \mathrm{C} / 2000 \mathrm{psi}$

\begin{tabular}{|c|c|c|c|c|c|}
\hline & $P \& T$ & 1 wk & 2 wk & $3 w k$ & $\begin{array}{l}\text { Post Run } \\
\text { Liquor }\end{array}$ \\
\hline $\mathrm{Si}$ & 82.4 & 398.0 & 448.0 & 460.0 & 72.3 \\
\hline Al & 7.5 & 10.1 & 9.3 & 8.6 & 4.5 \\
\hline $\mathrm{Fe}$ & 0.4 & 3.2 & 2.5 & 1.8 & 0.14 \\
\hline $\mathrm{Mg}$ & 0.25 & 0.2 & 0.2 & 0.2 & 0.1 \\
\hline$M n$ & 0.03 & 0.05 & 0.05 & 0.03 & 0.01 \\
\hline $\mathrm{Ca}$ & 1.5 & 1.5 & 1.15 & 1.03 & 2.4 \\
\hline $\mathrm{Na}$ & 17.2 & 63.3 & 84.8 & 127.0 & 93.4 \\
\hline K & 9.9 & 38.6 & 47.1 & 52.6 & 13.5 \\
\hline $\mathrm{Ti}$ & D.L. & 0.3 & 0.2 & 0.2 & 0.01 \\
\hline$P$ & 0.4 & 0.9 & 0.6 & 0.5 & 0.09 \\
\hline $\mathrm{Cr}$ & 0.01 & 0.05 & 0.06 & 0.09 & 0.08 \\
\hline $\mathrm{Ni}$ & 0.13 & 0.4 & 0.3 & 0.3 & 4.1 \\
\hline Cs & 0.02 & 0.03 & 0.11 & 0.03 & 0.08 \\
\hline $\mathrm{Sr}$ & 0.01 & 0.01 & 0.01 & 0.0 & 0.02 \\
\hline $\mathrm{Ba}$ & 0.03 & 0.03 & 0.03 & 0.02 & 0.06 \\
\hline Li & 0.02 & 0.06 & 0.08 & 0.07 & 0.03 \\
\hline B & 0.27 & 21.2 & 56.2 & 105.0 & 202.0 \\
\hline Mo & 0.27 & 11.1 & 32.9 & 63.3 & 22.3 \\
\hline Ru & D.L. & 0.04 & 0.06 & 0.06 & 0.03 \\
\hline $\mathrm{Sb}$ & 0.04 & 0.3 & 0.3 & 0.4 & 0.15 \\
\hline Zn & 0.21 & 0.2 & 0.2 & 0.2 & 0.02 \\
\hline $\mathrm{pH}$ & 7.5 & 7.9 & 7.8 & 7.9 & 7.7 \\
\hline $\mathrm{HCO}_{3}$ & & 79.6 & 101.2 & 111.0 & 121.0 \\
\hline $\mathrm{CO}_{3}$ & & 5.9 & 0 & 0.0 & 0.0 \\
\hline $\mathrm{SO}_{4}$ & & 32.8 & 37.8 & 40.2 & 32.3 \\
\hline$F$ & & 16.8 & 24.9 & 30.0 & 21.4 \\
\hline $\mathrm{NO}_{3}$ & & 0.5 & 0.4 & 0.3 & 0.5 \\
\hline $\mathrm{PO}_{4}$ & & 0.5 & 0.2 & 4.0 & 6.6 \\
\hline $\mathrm{Cl}^{-}$ & & 7.1 & 8.1 & 11.9 & 5.7 \\
\hline $\mathrm{MoO}_{4}$ & & 16.9 & 54.4 & 114 & 30.8 \\
\hline
\end{tabular}




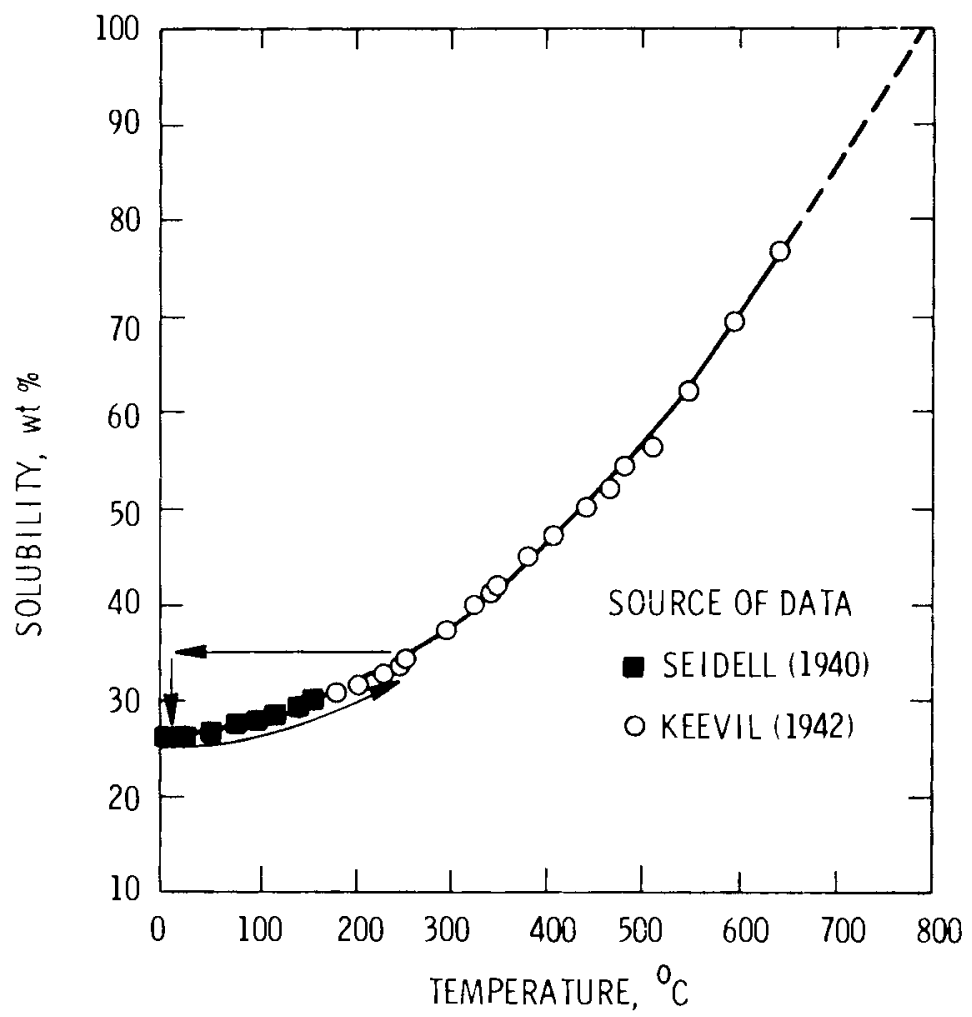

FIGURE 7. NaCl Solubility Along the Three Phase Liquid-Vapor-NaCl Curve. Modified from Holland and Malinin 1979

silica concentrations from the basalt packages are greater than from granite. As shown later, it is suggested that this is the result of dissolution of interstitial glass from basalt compared with quartz dissolution in granite. It appears that $\mathrm{CS}$ retention in basalt is greater than in granite and that solution of some glass comporients, notably B and Mo, are not effected by the rock matrix.

Compositions of solutions from the first series of $850 \mathrm{ml}$ direct sampling autoclave runs are presented in Tables 8 and 9 for basalt and granite packages respectively, and the cation-anion concentrations in the cooldown liquid is given in Table 10. The initial solution used in these runs was DI water so the data represent the evolution of the solution composition over a $4 \mathrm{wk}$ period. Because of different sample configurations, solution volumes, and possibly lower reducing conditions, these data may not be directly comparable with the digestion bomb tests, but they exhibit the same trends as the smaller volume tests. 
The solution compositions of the second series of direct sampling autoclave granite and basalt tests are presented in Tables 11 and 12. The cation concentrations obtained from acidified samples of these solutions appear to be generaliy comparable with the diluted samples up through the 3 wk period. The pressure was dropped to 1000 psig during the last week of these runs and the concentratons of $\mathrm{Si}, \mathrm{B}$, Mo, and $\mathrm{SO}_{4}$ for example are not in agreement with the first series concentrations. A crude estimate of the electroneutrality balance was calculated from the 3 wk data using only $\mathrm{Na}^{+}$and $\mathrm{K}^{+}$as cations and $\mathrm{HCO}_{3}^{-}, \mathrm{MoO}_{4}^{-}, \mathrm{SO}_{4}^{-}, \mathrm{F}^{-}$, and $\mathrm{Cl}^{-}$as anions. Agreement within $10 \%$ was found, but this is admittedly a simplified estimate assuming B, for example, is not ionized. The relatively high bicarbonate concentrations were surprising but are compatible with some geothermal data from similar rock types. These values are presumably due to the partial solution of trace amounts of carbonate minerals in the original rock.

During the cooldown period of the first series of direct sampling autoclave experiments, $5 \mathrm{ml}$ samples of solution were extracted into $20 \mathrm{ml}$ of DI water at approximately $50^{\circ} \mathrm{C}$ temperature intervals. The purpose of this was to estimate the precipitation effects of relatively slow cooling as opposed to quenching. The results of these analyses are given in Table 13. In general, they indicate that silica precipitates during the cooldown period as expected but that the more soluble elements such as $\mathrm{B}$, Mo, Na, and Cs are relatively unaffected.

The silica data from these analyses is plotted in Figure 8 which depicts the temperature effect on amorphous silica and quartz solubilities. Figure 8 suggests that these experiments have not reached equilibrium, but they also imply, by the difference of silica concentrations from basalt and granite packages at $250^{\circ} \mathrm{C}$, that silica from basalt may be derived from amorphous silica while that from granite may be from crystalline silica. During the cooldown period, silica concentrations from both packages follow solubility trends of amorphous silica equilibration. In support of this observation, considerable amounts of amorphous silica material was observed by SEM examination on glass and rock package components. 
TABLE 13. Series I Solution Concentrations During Autoclave Cooldown, $\mu \mathrm{g} / \mathrm{ml}$

\begin{tabular}{|c|c|c|c|c|c|c|c|}
\hline & \multicolumn{7}{|c|}{ Basalt $\mu \mathrm{g} / \mathrm{ml}$} \\
\hline & $250^{\circ} \mathrm{C}$ & $200^{\circ} \mathrm{C}$ & $150^{\circ} \mathrm{C}$ & $100^{\circ} \mathrm{C}$ & $65^{\circ} \mathrm{C}$ & $20^{\circ} \mathrm{C}$ & $L$ \\
\hline Si & 515 & 504 & 481 & 298 & 255 & 211 & 134 \\
\hline $\mathrm{Ca}$ & 0.4 & 0.4 & 0.3 & 0.3 & 0.4 & 0.4 & 0.5 \\
\hline B & 126 & 126 & 124 & 128 & 128 & 126 & 117 \\
\hline Cs & 0.3 & 0.25 & 0.2 & 0.1 & 0.1 & 0.1 & 0.1 \\
\hline Mo & 73 & 73 & 74 & 75 & 75 & 75 & 80 \\
\hline $\mathrm{Zn}$ & 0.4 & 0.5 & 0.4 & 0.3 & 0.3 & 0.4 & 0.02 \\
\hline $\mathrm{Na}$ & 125 & 133 & 125 & 134 & 129 & 134 & 139 \\
\hline
\end{tabular}

Granite $\mu \mathrm{g} / \mathrm{ml}$

\begin{tabular}{|c|c|c|c|c|c|c|}
\hline & $250^{\circ} \mathrm{C}$ & $200^{\circ} \mathrm{C}$ & $150^{\circ} \mathrm{C}$ & $100^{\circ} \mathrm{C}$ & $50^{\circ} \mathrm{C}$ & L \\
\hline $\mathrm{Si}$ & 250 & 250 & 242 & 240 & 241 & 193 \\
\hline $\mathrm{Ca}$ & 0.3 & 0.3 & 0.45 & 0.5 & 1.2 & 4.6 \\
\hline$B$ & 92 & 92 & 90 & 90 & 93 & 83 \\
\hline Cs & 2.9 & 2.6 & 2.3 & 2.4 & 2.0 & 2.8 \\
\hline Mo & 18 & 18 & 17.5 & 17.7 & 18.3 & 19.2 \\
\hline Zn & 0.1 & 0.3 & 0.3 & 0.3 & 0.4 & 0.04 \\
\hline $\mathrm{Na}$ & 112.4 & 114.8 & 110.9 & 109.8 & 113.7 & 103 \\
\hline
\end{tabular}

$L=$ Solution remaining in autoclave after cooldown and opening - analyzed one week after collection.

One of the objectives of conducting waste package tests is to support the development of source-term and related geochemical models. Most of the thermochemically-based geochemical models currently available were developed for application to processes such as groundwater chemical evaluation or ore deposit genesis which generaliy exclude many of the repository components. It is recognized that these models will require some degree of modification to acheive desirable source-term applications. To get a general idea of the extent of modification that might be necessary, some of the cation and anion 


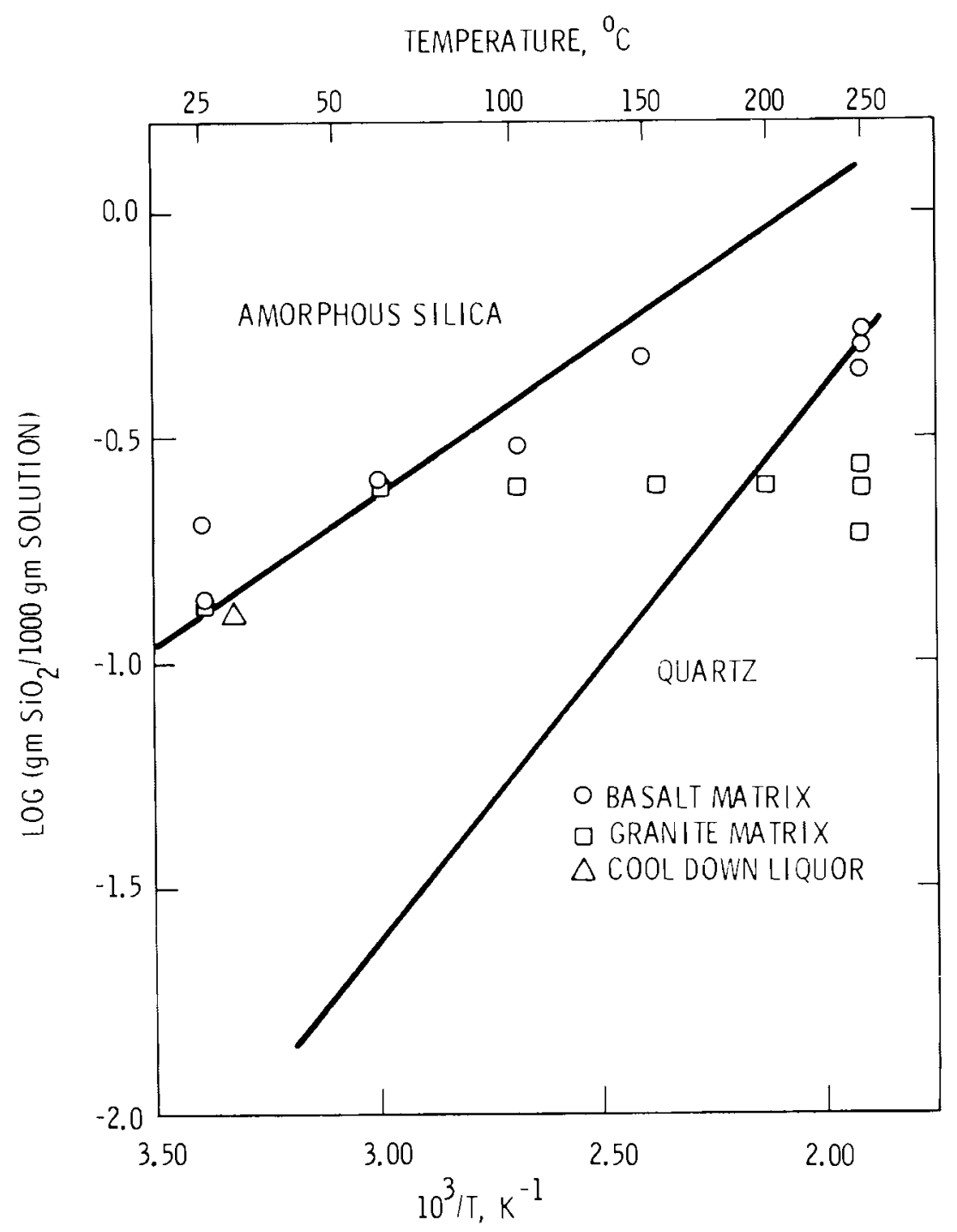

FIGURE 8. Amorphous and Crystalline Silica Solubility. Modified from Holland and Malinin 1979

solution data from the second series of waste package tests were used in a trial run as input to the USGS model WATEQ 2. The choice of model was purely convenience because the model is operational locally. It was originally developed as a groundwater chemical equilibria model and does not consider Mo, $B$, and $C s$. As expected, because of compositional and temperature difference, the results were not successful in predicting secondary phase occurrence. The results indicated, however, that models involving initial cation-anion mass balances will need to include molybdate and borate species, the data base should include Cs-bearing solid phases, and that it may be desirable to include host rock-secondary mineral hydrolysis reactions as part of the data base in addition to secondary mineral solubility products. 


\section{SOLID COMPONENT ANALYSIS}

At the present time, analysis of the solid components from the waste package tests has been restricted to examination of the glass surfaces of the minicanisters, and the rock wafers in contact with the glass. Future work will include XRD to facilitate identification of secondary alteration products. It is also anticipated that trace element distribution analysis will be conducted on the rock matrix powders to assess element migration patterns.

Figures 9 thru 12 show the glass-rock contact surfaces after removal from package tests. It is apparent that some crack development has occured in the glass, probably as a result of canister fabrication and preparation. Figure 9 is the contact surface of a granite wafer and glass that was removed from a preliminary autoclave test. In a sense, this preliminary run was a failure because the autoclave developed a slow leak and nearly all the liquid phase was lost during the 30 day run at $250^{\circ} \mathrm{C}$ and $2000 \mathrm{psi}$. Evidence is presented later, however, to indicate that $U$ and $Z n$ have migrated from the glass into the granite pellet. Mobility of these elements is consistant with the observed Fe staining which suggests that redox conditions were somewhat oxidizing during this run. This experiment also inspired the second series of autoclave runs during which the pressure was purposely lowered to create a single vapor, phase. As shown later, U migration on, and into, the rock wafer was observed in these experiments but was not encountered in experiments where the waste package remained submersed in a liquid phase throughout the run. Figures 10 thru 12 are glass-rock surfaces from granite, basalt, and salt packages, respectively, that were run in digestion bombs at $250^{\circ} \mathrm{C}$. Some corrosion is evident. The coating on the granite components is mostly adhering rock matrix powder with lesser amounts of corrosion products.

\section{SEM EXAMINATION}

The minicanister surfaces in contact with the rock wafers were examined by Scanning Electron Microscoping (SEM) with an energy dispersive $x$-ray (EDX) attachment in an attempt to determine the nature of precipitation and alteration phases. These surfaces consisted of the glass core surrounded by a 


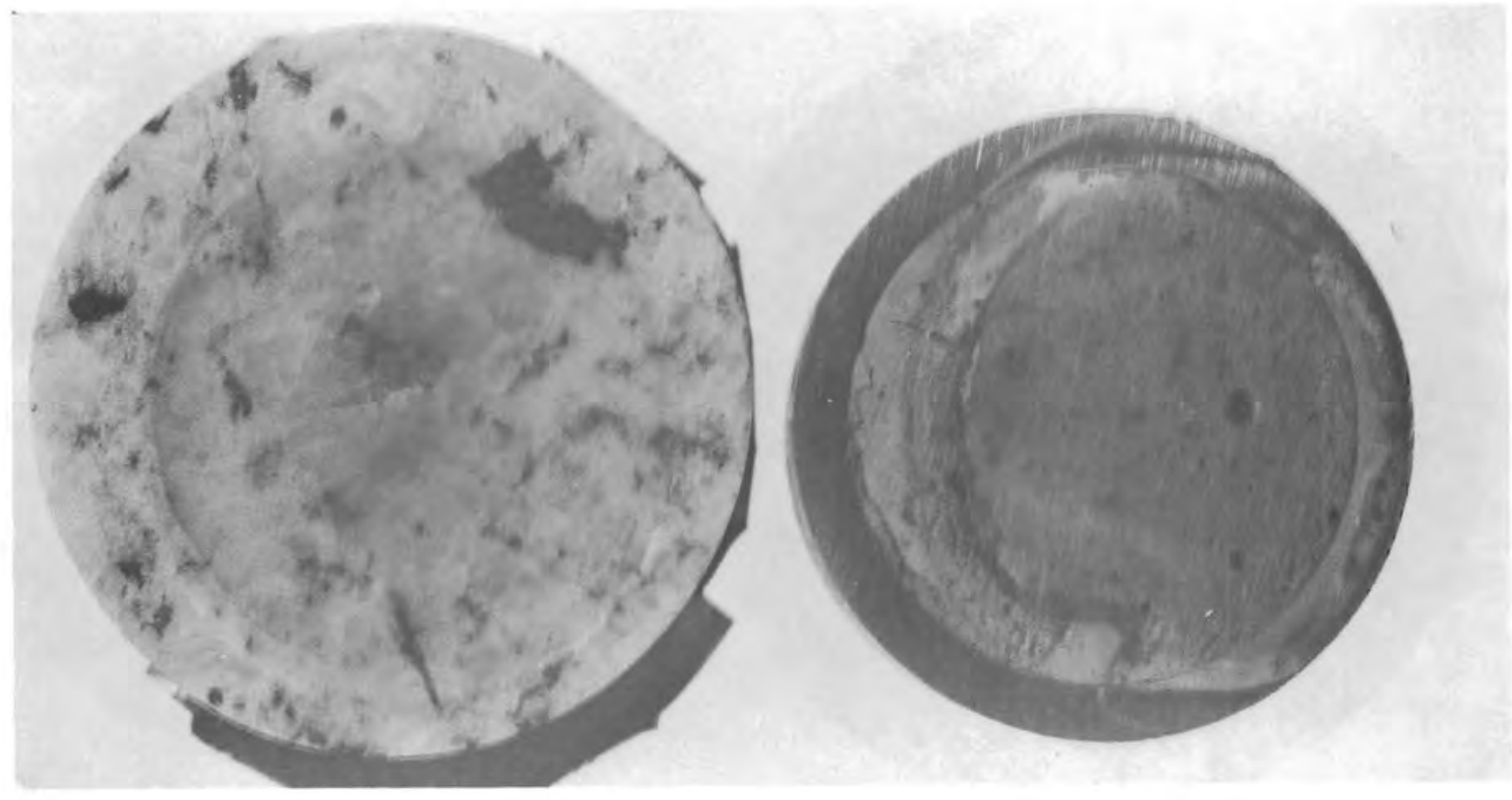

FIGURE 9. Contact Surfaces of Granite and Glass Wafers from Preliminary Large Volume Autoclave Test.

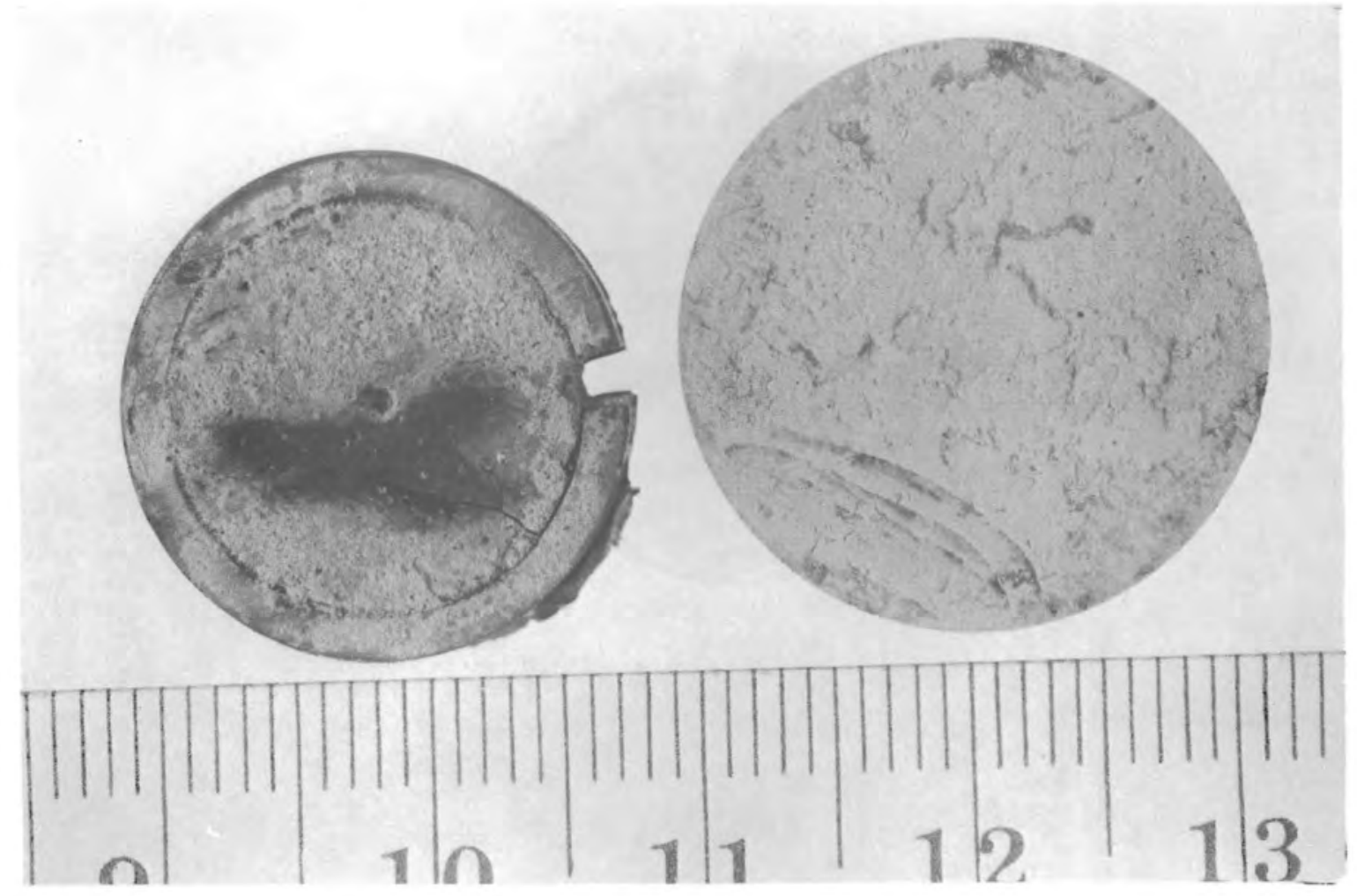

FIGURE 10. Glass-Rock Surfaces from Granite Digestion Bomb Tests at $250^{\circ} \mathrm{C}$ 


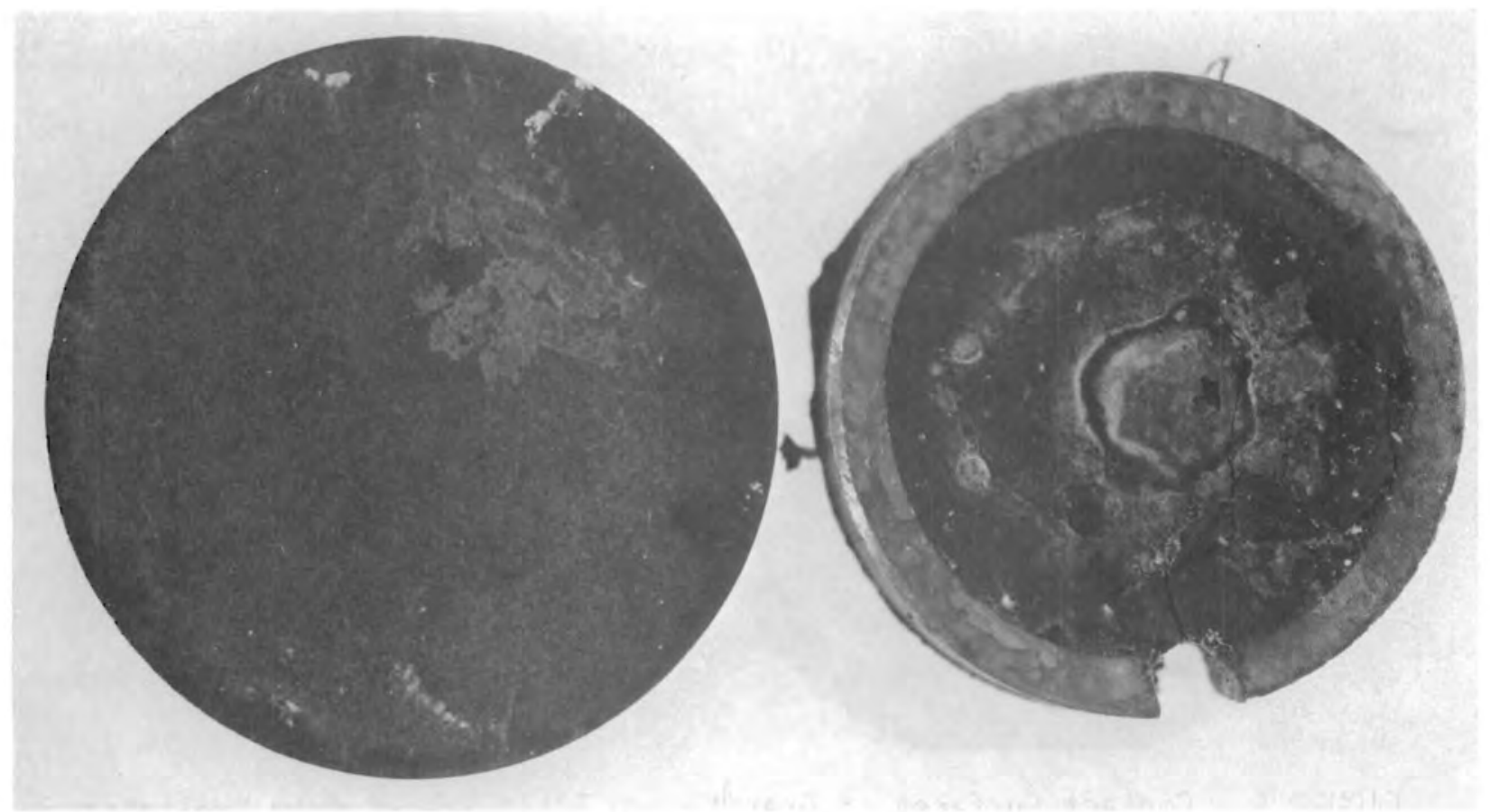

FIGURE 11. Glass-Rock Surfaces from Bāsalt Digestion Bomb Tests at $250^{\circ} \mathrm{C}$

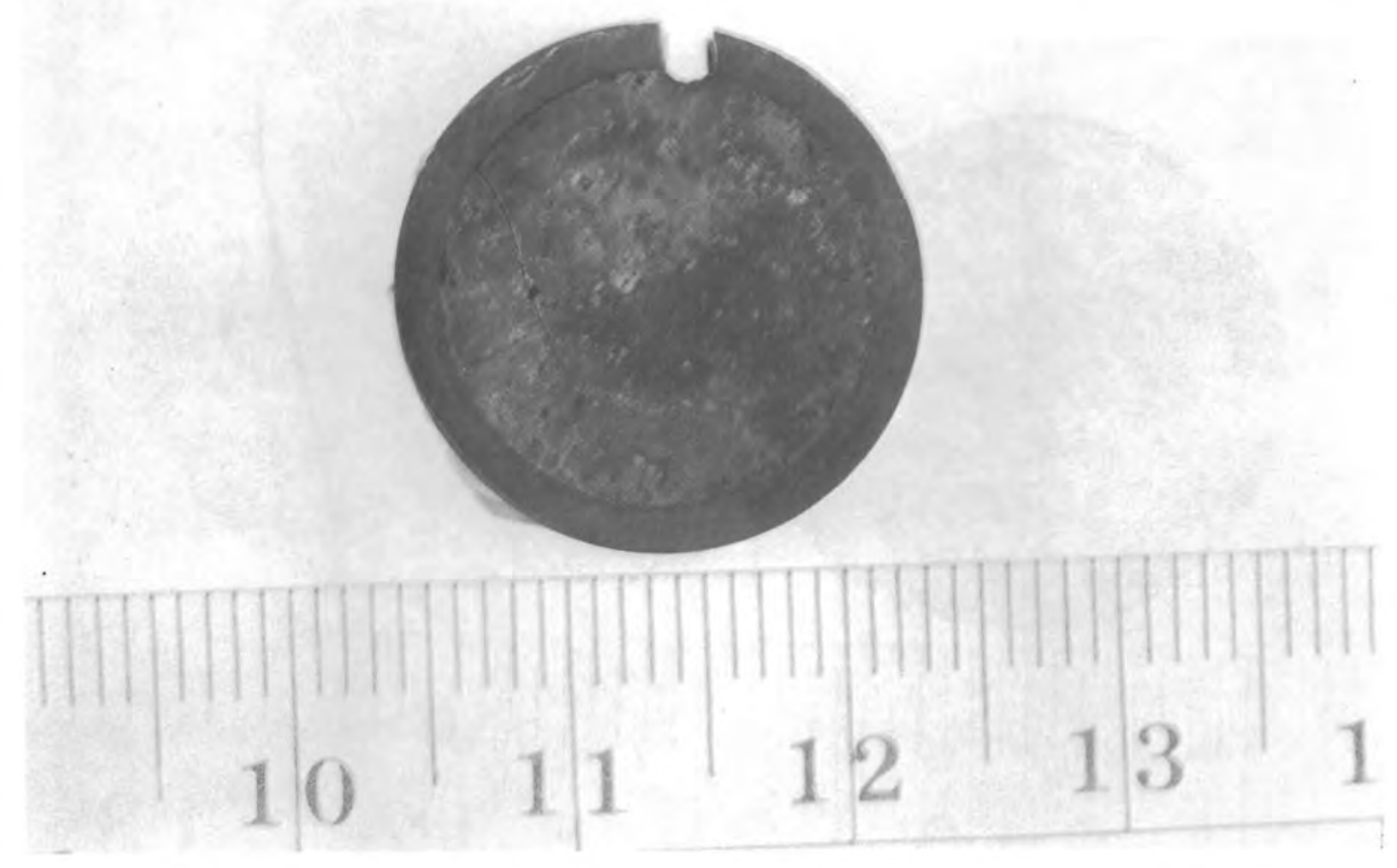

FIGURE 12. Glass Surface from Salt Digestion Bomb Test 
rim of the stainless steel canister. The general procedure was to scan the surfaces at low magnification, then to examine observed alteration products at higher magnification. A photomicrograph of these products was taken from the secondary electron images, and their qualitative chemical composition was estimated from their x-ray spectra. In some cases of small particle sizes, or thin coatings, the primary beam penetrates the product of interest and generates $x$-ray spectra from the substrate in addition to the product spectra. This was particularly evident on some silica gel precipitates on the stainless steel canister material.

The identity of individual solid phases can only be assumed by this method, but in many cases reasonable guesses can be made based on a combination of morphological characteristics and qualitative chemistry. Confirmation requires chemical analys is and $x$-ray diffraction techniques. It is expected that these methods will be utilized more in future work.

Examples of some of the secondary phases observed on glass-canister surfaces are shown in Figures 13a thru $13 \mathrm{c}$ and other examples are compiled in Appendix $A$. These figures are photomicrographs of selected surface areas and in most cases include the EDX spectra associated with individual areas or phases. The photomicrographs are labled according to specific waste package tests which are described as follows:

Figure 13a thru 13b. WPIT-01.

These figures show the canister surface of the first waste package test using a granite matrix that was run in the 3.8 liter autoclave that developed a slow leak. The first photomicrograph at low magnification includes both the glass and canister. It illustrates a separation of the glass from the inner wall of the canister which is typical. Small radiating crystal clusters are also observed on this surface. The next two figures suggest that the radiating clusters are a zinc silicate, possibly the mineral willemite $\mathrm{Zr}_{2} \mathrm{SiO}_{4}$ and that spherical, gel-like beads that are primarily uranium also appear on the surface. Other phases in the next two figures show precipitated silica gel on the canister surface and small calcium phosphate needles, probably apatite, $\mathrm{Ca}_{5}\left(\mathrm{PO}_{4}\right)_{3} \mathrm{OH}$, clustered around U-bearing spheres. 


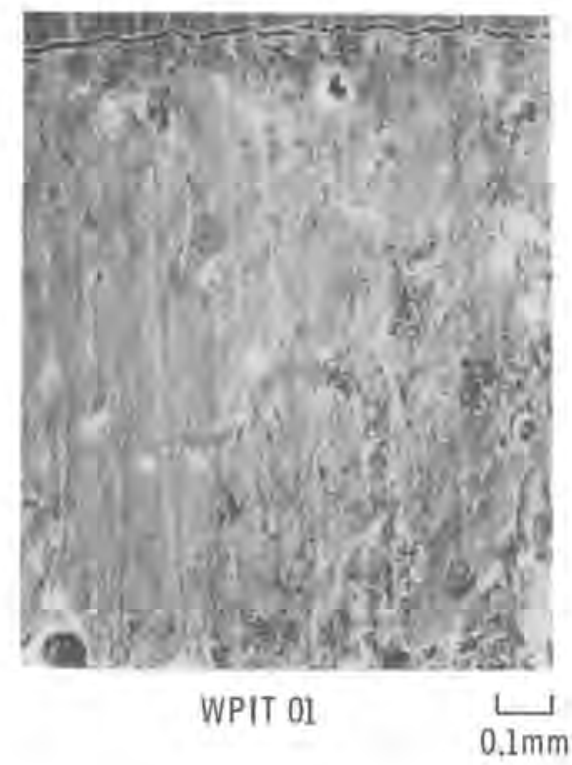

FIGURE 13a. Glass Surface from Preliminary Autoclave Test -Granite Package exposed to vapor phase. Glass-Canister Surface at Low Magnification

Figures 14 thru 16. 07TG.

These figures are photomicrographs of polished surfaces of a cross section of the granite minicanister cut at midheight. It was prepared with the object of examining canister-rock interactions in the vicinity of the vertical slit cut through the canister wall of the granite matrix, 07TG, run. The first two photomicrographs Figure 14 show the microstructure near the slit and the glass-rock powder interface. Note that within the granite powder is an apparently unreacted pyrite crystal with a small uranium crystal adjacent. In the remaining two figures, the associated EDX spectra, all recorded at the same scale expansion, depict uranium migration in the vicinity of the slit. Figure 16 shows the glass-rock contact area and the EDX spectra suggest that uranium has been somewhat depleted in the glass and has migrated into the rock material. Figure 15 shows a similar migration into fracture fillings of the glass. It should be emphasized that the observed uranium mobilization zone represents a distance of about $10 \mu \mathrm{m}$ suggesting a uranium migration rate of $0.3 \mu \mathrm{m} /$ day. No evidence of uranium was observed on the rock wafer in this run as expected because the presence of unaltered pyrite implies relatively reducing conditions. 

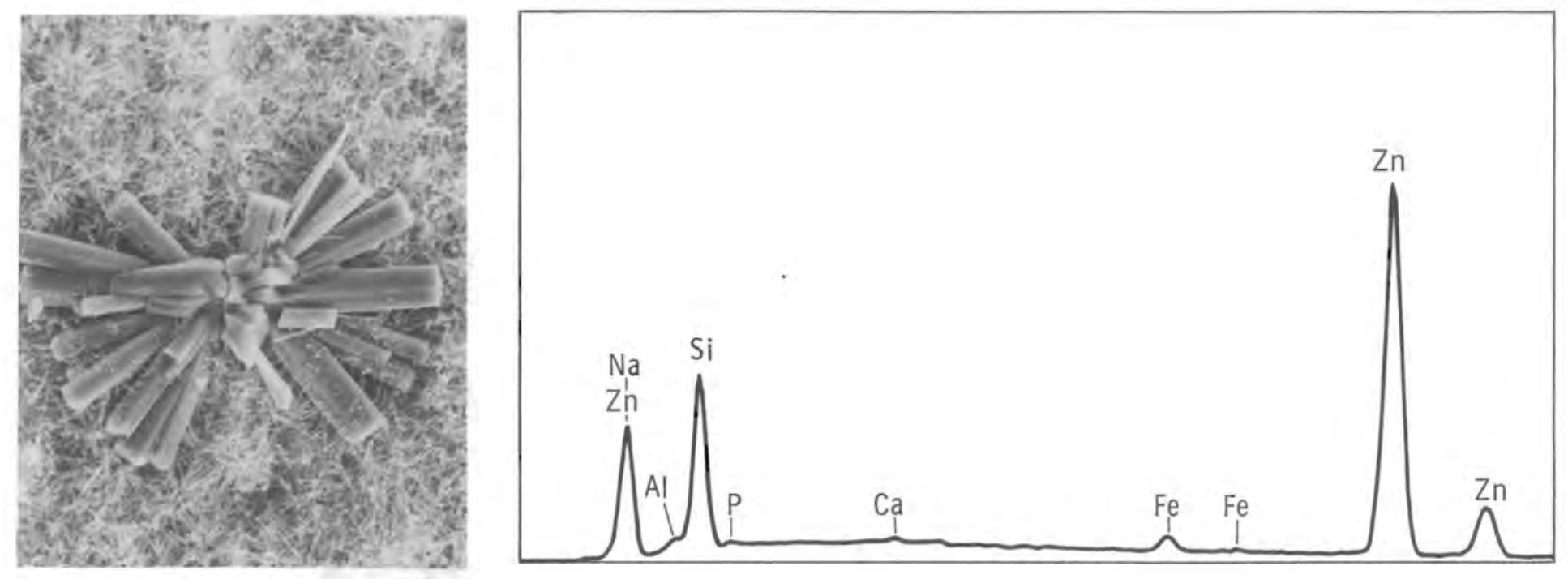

WPIT 01

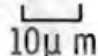
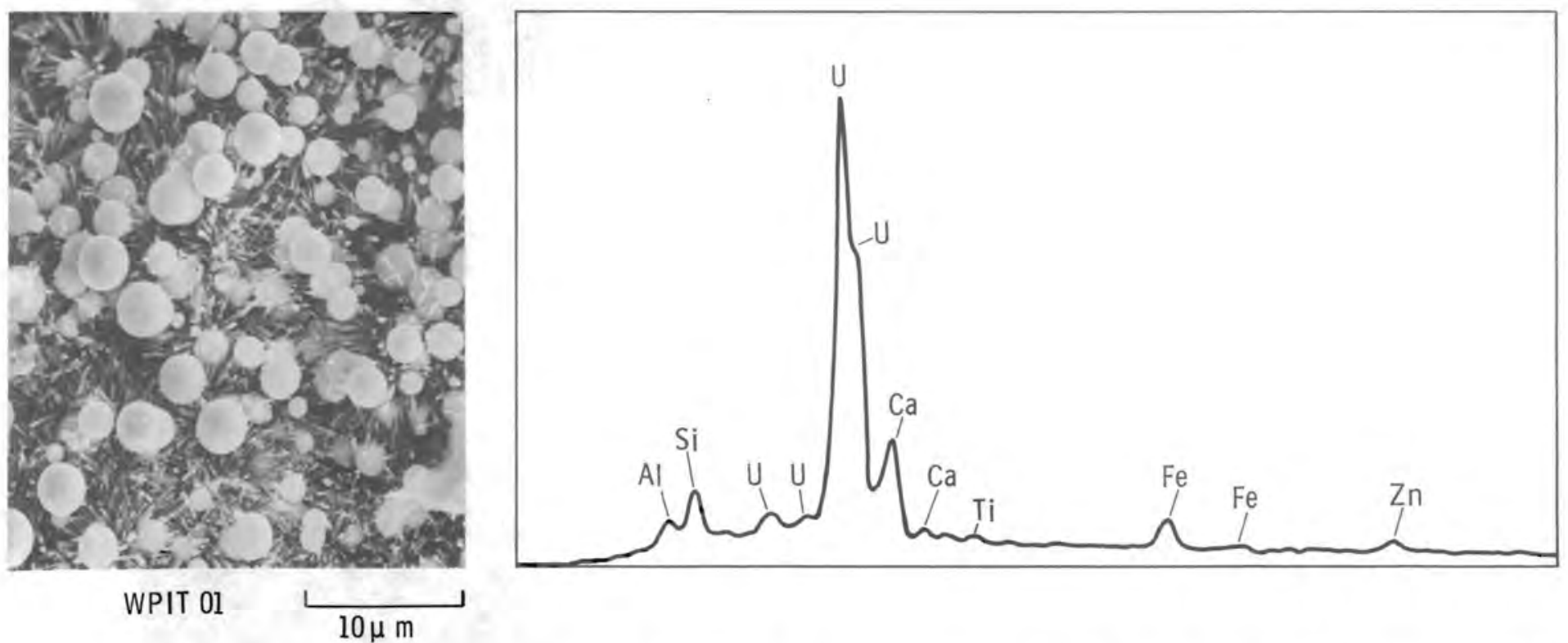

FIGURE 13b. Glass Surface from Preliminary Autoclave Test-Granite Package exposed to vapor phase. Zinc Silicate Crystals and Uranium Spheres 

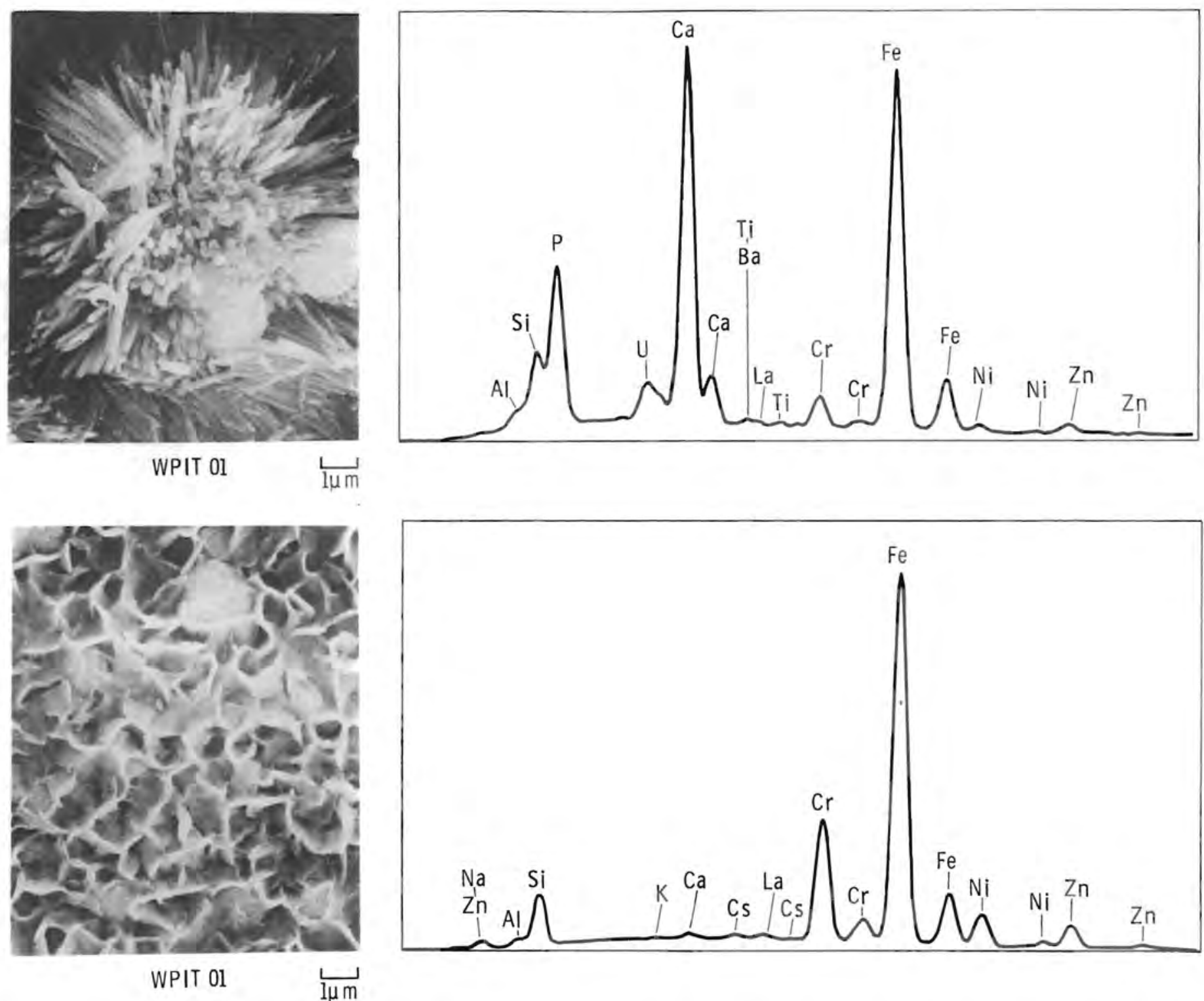

FIGURE 13c. Glass Surface from Preliminary Autoclave Test-Granite Package exposed to Vapor Phase. Silica Gel Precipitate and Calcium Phosphate Needles 

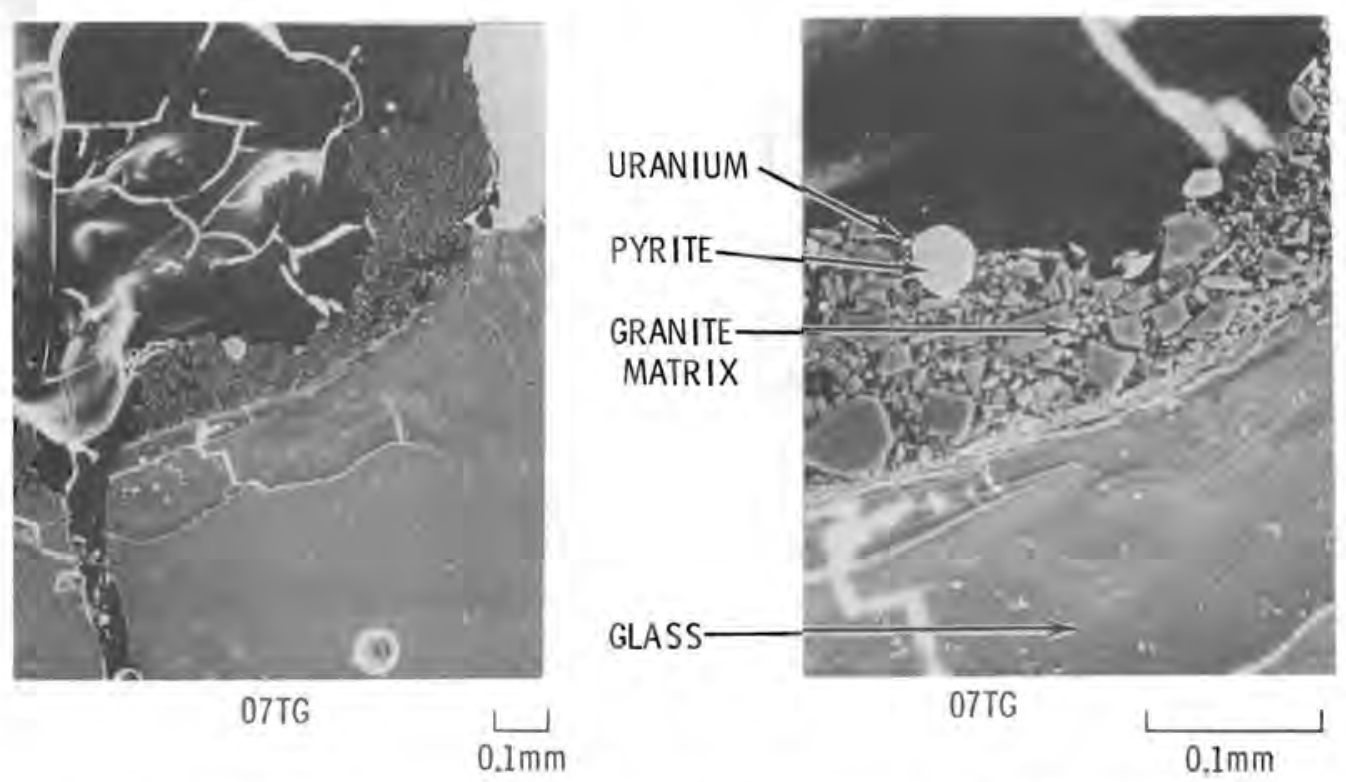

FIGURE 14. Polished Cross Section of Canister at Mid-Height at Area of Vertical S1it. Granite-Digestion Bomb Package

ROCK PELLET SURFACE ANALYSIS

The surfaces of several rock pellets in contact with the minicanister glass surface was examined by $x$-ray photoelection spectroscopy. (XPS) for evidence of element mobility from the glass to the rock wafer surface. The exciting photon source was $\mathrm{Mg} \mathrm{K}$ and the effective depth of element determination was 10 to $30 \mathrm{~A}$. The XPS spectral intensities presented here are only semiquantitative; their main purpose is for element identification.

Figure 17 shows the XPS spectra of a fresh granite pellet that was not used in a package test compared with the granite pellet used in the first preliminary 3.8 liter autoclave test that developed the slow leak during the run. The uranium spectra occur at a binding energy of about-380 eV and it is evident in comparing the two spectra that $U$ has migrated to the rock wafer surface. Other elements that show an increase in concentration at the rock surface are $\mathrm{Zn}$ and $\mathrm{Fe}$, while $\mathrm{Si}$ has been depleted. The amount of uranium on the rock surface is estimated at 0.4 atomic percent. These results are consistant with the observations of Fe staining, zinc silicate crystals, and uranium-bearing spheres on the glass surface from the SEM examination. Additional examples of XPS spectra showing this behavior in basalt package tests and another granite package test are in Appendix B. 


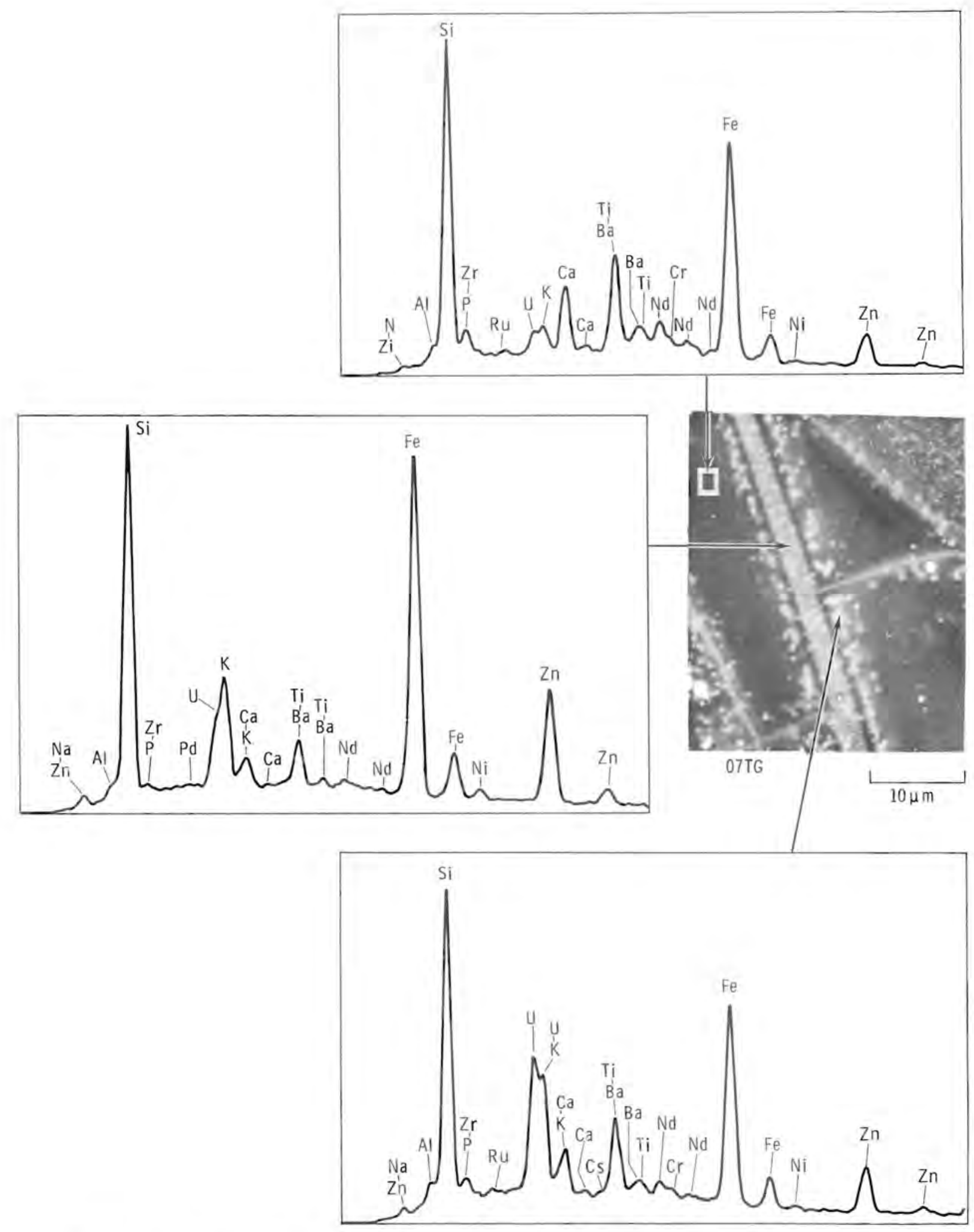

FIGURE 15. Fracture Area in Glass Near Vertical Slit. Magnified from Figure 14. Note Uranium Migration from Glass Into Fracture 

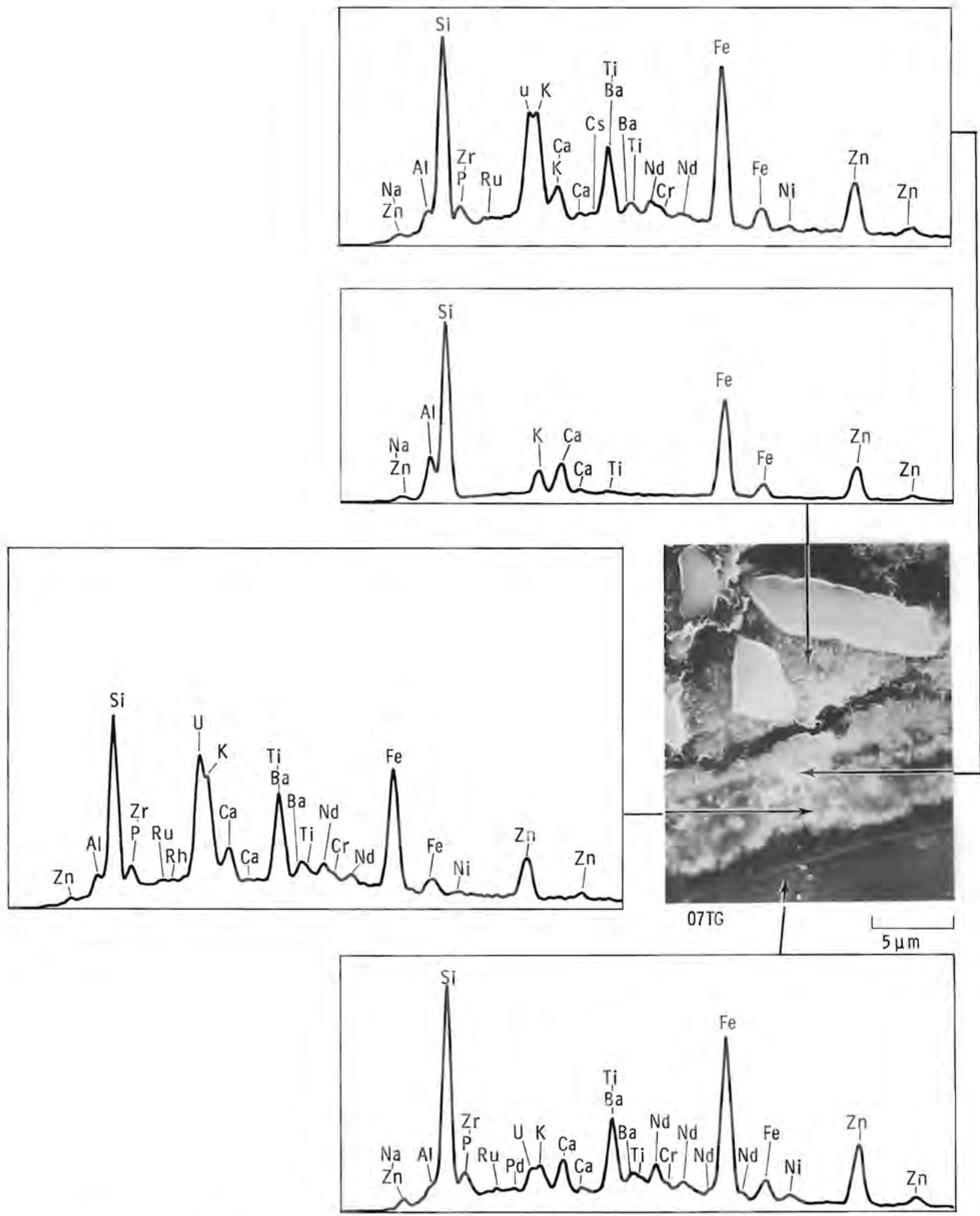

FIGURE 16. Glass-Rock Powder Interface Area Magnified from Figure 21. Note Uranium Migration Into Rock Material 

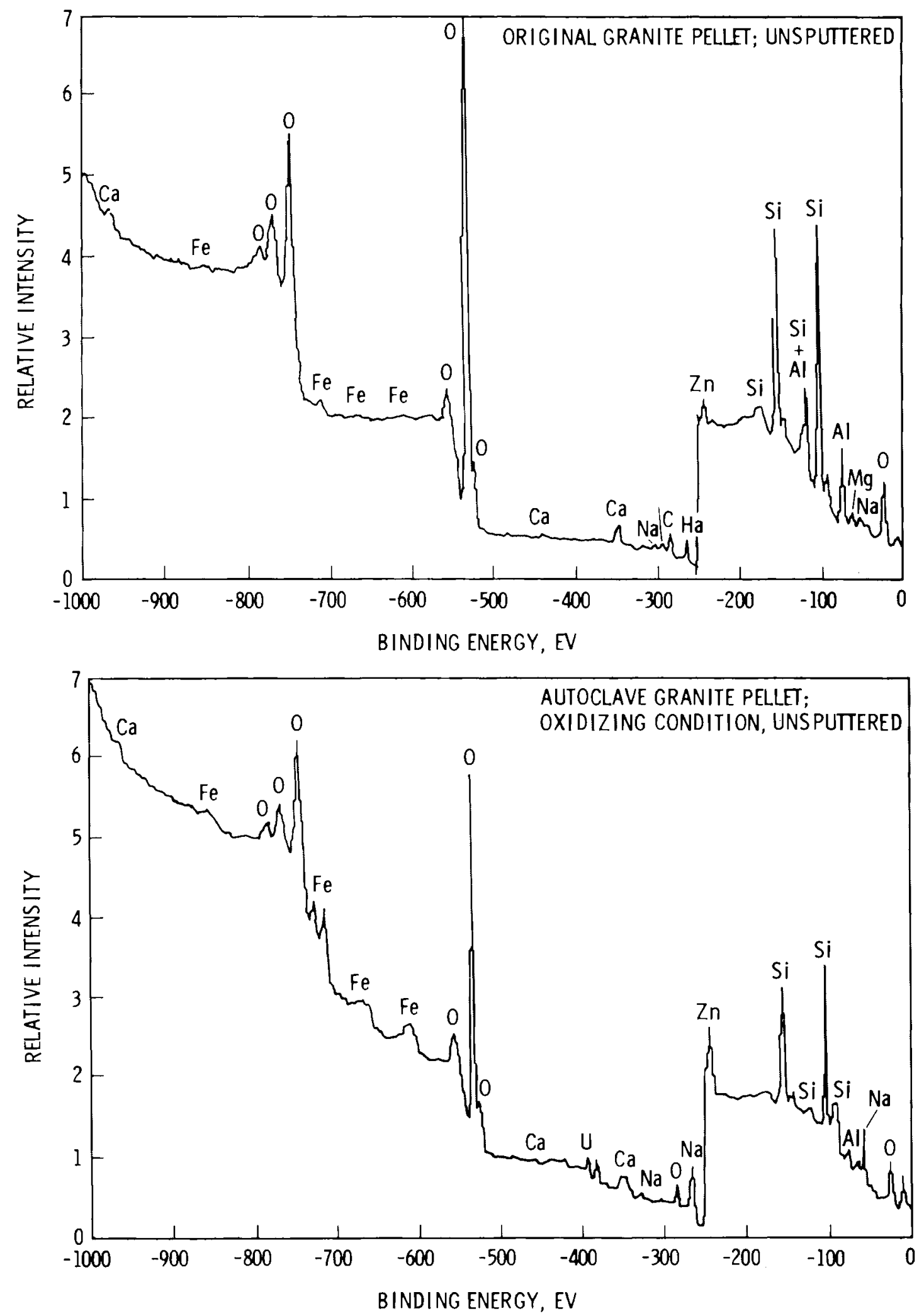

FIGURE 17. XPS Spectra from Surface of Granite Pellet Exposed to a Vapor Phase. (Lower) Compared with Original Pellet (Upper). Note Presence of Uranium on Autoclave Pellet 
It is apparent from these preliminary studies that XPS is a strong tool for determination of element mobility, and when combined with sputtering techniques, should offer considerable insight into element migration mechanisms. 
DISCUSSION

There are numerous investigations of rock-water interactions at hydrothermal conditions reported in the literature, but only a few of these, such as McCarthy et a1. 1978, and Komarneni, et a1. 1980, have included waste forms in the systems. The previous waste-rock studies may not be directly comparable with the present investigation because of different component mass ratios and compositions. For example, the minerial weeksite, $\mathrm{K}_{2}\left(\mathrm{UO}_{2}\right)_{2}\left(\mathrm{Si}_{2} \mathrm{O}_{5}\right)_{3}$ $4 \mathrm{H}_{2} \mathrm{O}$, was observed as an alteration product by McCarthy et al. 1978 but was not conclusively identified in any of the waste package tests. This was presumably due in part to the small amount of available $\mathrm{UO}_{2} ; 0.5 \%$ of the package at best in some of the digestion bomb tests or to a lower chemical potential of $\mathrm{H}_{2} \mathrm{O}$. The solution data from the waste package tests, however, can be compared with hydrothermal studies of 76-68 glass and water interactions. Also, compositions of water from some geothermal areas from aquifers in similar rock types are generally similar to waste package solution compositions which suggests that the rock buffering characteristics may be similar.

COMPARISON WITH GLASS-WATER INTERACTIONS

Hydrothermal leaching data of 76-68 glass from the same batch used in the waste package tests is reported by Westsik and Harvey 1980. Their study used glass beads and leach solutions sealed in gold capsules and run at either $150^{\circ}$ or $250^{\circ} \mathrm{C}$ and 2000 psig for time periods up to 32 days. The surface area to solution volume ratio was about $0.1 \mathrm{~cm}^{-1}$ and the bead to solution mass ratio was about 0.02 . On the basis of the mass of glass used in the first series of waste package tests, the glass to solution mass ratio was about 0.06 . The surface area of the glass in the minicanisters is not known because of variable amounts of fracturing, and unknown surface area exposure at the glass-canister interface. In spite of these differences, it seems desirable to compare the solution compositions from the two tests in order to obtain a preliminary assessment of the effect of the rock matrix on glass leaching.

Boron and molybdenum are among the most mobile elements leached from glass waste forms. Figure 18 compares the solution concentrations of these 


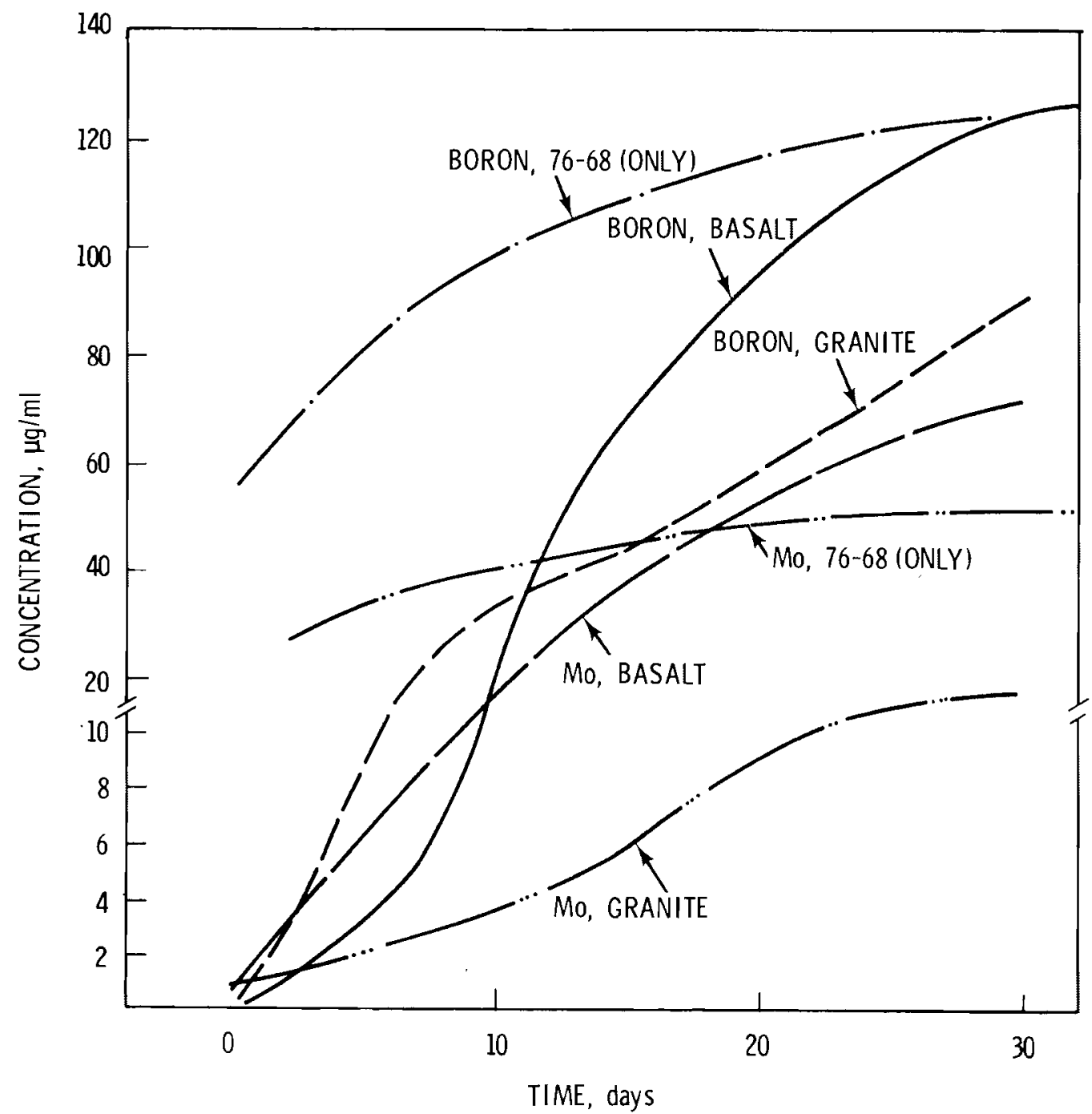

FIGURE 18. Solution Concentrations as a Function of Time for $B$ and Mo from Waste Package Tests Compared With 76-68 Glass Without Rock Media Present at $250^{\circ} \mathrm{C}, 2000$ psig

elements from gold capsule experiments and from the first series of waste package tests both at $250^{\circ} \mathrm{C}, 2000 \mathrm{psi}$. These curves were each drawn through at least four sample data points, but were not replicated. On the bas is of ICP precision, it is assumed that the curves are within $10 \%$ of the ir indicated value. It appears that after 30 days at $250^{\circ} \mathrm{C}$ and $2000 \mathrm{psi}$, both $\mathrm{B}$ and Mo have not yet reached a steady state. It is also apparent that the concentrations of these elements in the solutions extracted at weekly intervals from 
the package tests tend to approach the concentrations in solution from the glass alone. This suggests that the rock media has no effect on inhibiting the release of $B$ and Mo from 76-68 glass.

Both $\mathrm{Na}$ and $\mathrm{Si}$ are common elements of granite, basalt, and 76-68 glass. Figure 19 compares these elements from the package tests with glass only experiments. The Si concentration from the basalt packages tends to approach the concentration from the glass, both of which are at higher concentrations than $\mathrm{Si}$ from the granite packages. This suggests that Si from basalt may be derived from an amorphous $S i$ source as mentioned previously, but that the $S i$ from the granite packages is derived from a crystalline source. A similar argument could be proposed for $\mathrm{Na}$ which is generally lower in the package tests than the glass. If the $\mathrm{Na}$ from the package tests is derived from crystalline phases rather than amorphous phases, lower $\mathrm{Na}$ concentrations in solution would probably be expected. Cs would be expected to exhibit a behavior similar to $\mathrm{Na}$ and Figure 20 indicates that it does. The identity of the phase or phases in the package tests that might be responsible for the reduced $\mathrm{Cs}$ concentrations in the package solutions compared with glass will require more solid phase characterization than has been completed to date. Komarneni et al. 1980, however suggest that pollucite, $\mathrm{CsAlSi}_{2} \mathrm{O}_{6} \mathrm{H}_{2} \mathrm{O}$ or a polluciteanalcime solid solution may be a likely prospect.

ICP analysis of the package solutions failed to detect uranium. Several of these solutions were then analyzed for $U$ by a laser colorimetric spectrometer that had lower detection limits than ICP. A maximum of $15 \mathrm{ppb} U$ was found in one salt solution, but most levels were less than $4 \mathrm{ppb}$. In comparison, Westsik and Harvey (1980) report up to 5 ppm $U$ in their binary tests at $250^{\circ} \mathrm{C}$ in deionized water and up to $26 \mathrm{ppm}$ in WIPP B brine after 32 days leaching.

COMPARSION WITH GEOTHERMAL DATA

The pressure temperature regime under which the waste package experiments were conducted suggest that the solution chemistry may be comparable to geothermal solution chemistry in similar rock systems provided the rock-water interactions dominate the glass-water interactions. A brief search of the 


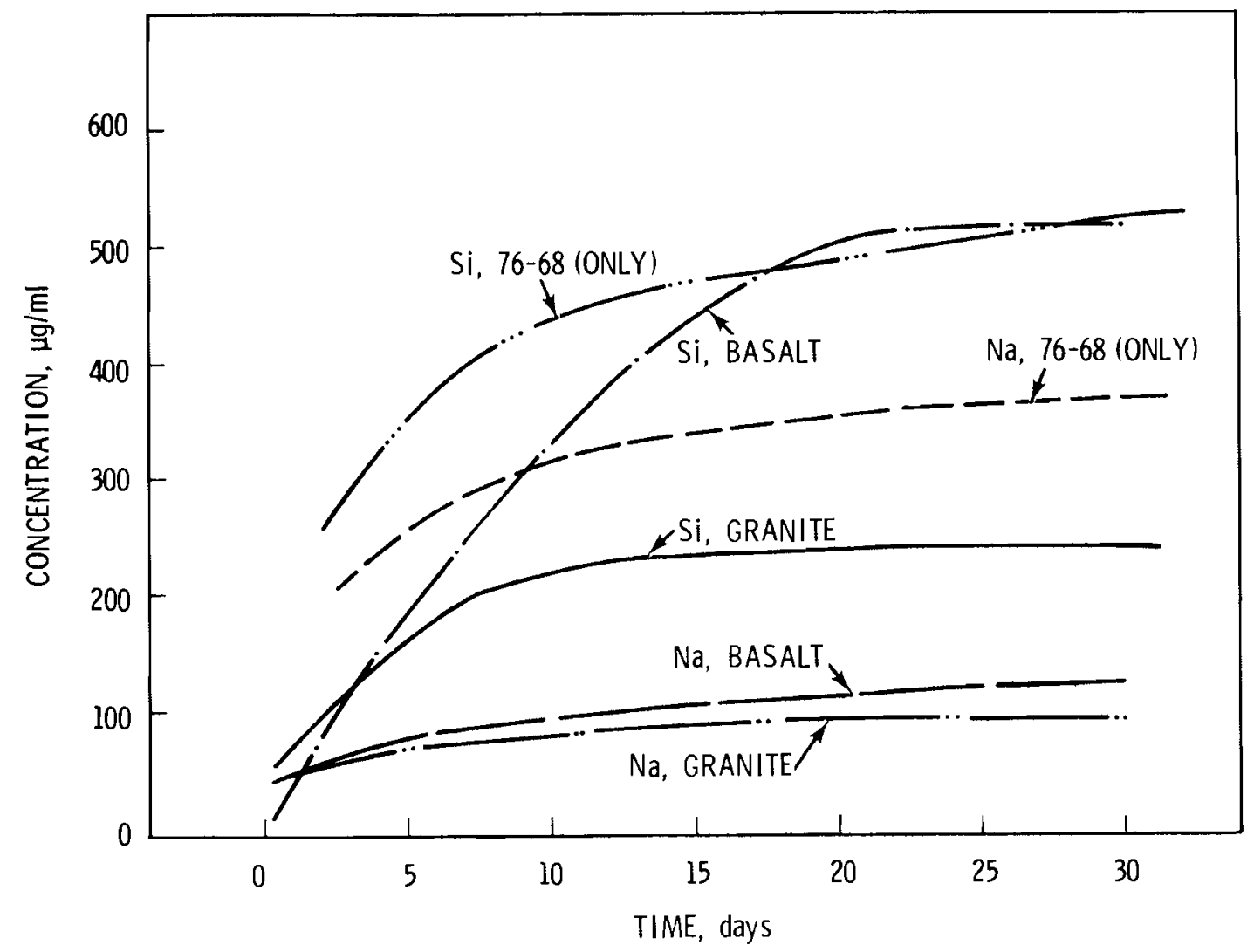

FIGURE 19. $\mathrm{Na}$ and Si Solution Concentrations as a Function of Time for Waste Package Tests Compared With 76-68 Glass Without Rock Media Present at $250^{\circ} \mathrm{C}, 2000 \mathrm{psig}$

literature yielded two comparable geothermal areas. Undoubtedly there are others, but an exhaustive search was not made. The two areas are Broadlands, New Zealand and Wairakei, New Zealand (Ellis 1979). The Broadlands area is dominated by rhyolitic flows and graywackes while rhyolitic volcanics with local occurences of andesite are present at Wairekei. In terms of bulk chemistry these rock types are generally similar to the basalt and granite used in the waste package tests. One difference between the two is the high dissolved $\mathrm{CO}_{2}$ present at Broadlands compared with Wairakei. The concentrations of several cations and anions from the second series of waste package tests collected after three weeks are compared with similar data from Braodlands and Wairekei in Table 14. It is evident that these data are roughly similar considering the complexity of the systems and the short time period for the hydrothermal runs. 


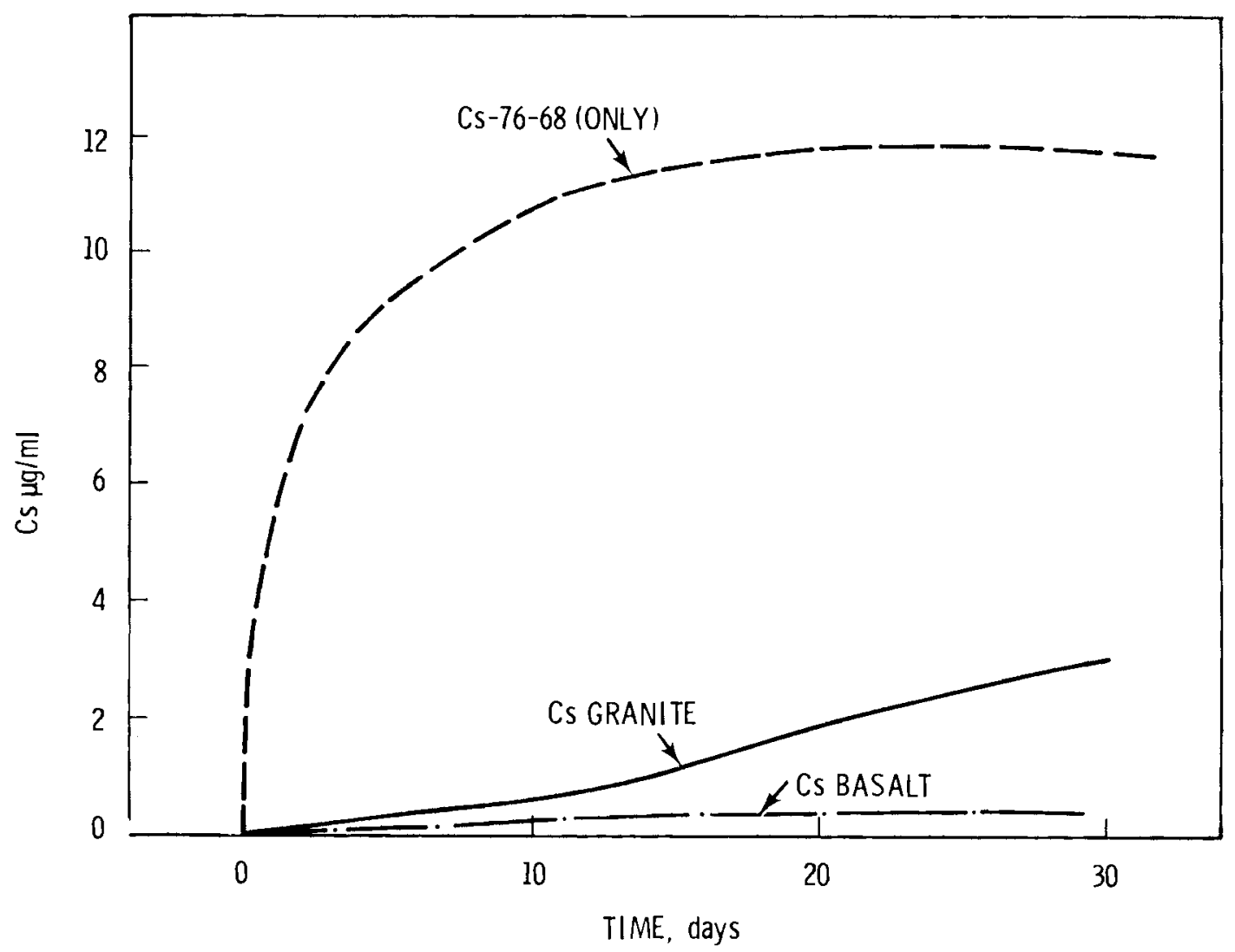

FIGURE 20. Cs Solution Concentrations as a Function of Time for Waste Package Tests Compared with 76-68 Glass Without the Presence of Rock Media at $250^{\circ} \mathrm{C}, 2000$ psig

The apparent similarity of solution chemistry between the waste package tests and the geothermal data suggest that the hydrothermal alteration or secondary mineral development may also be similar. Although solid phase characterization of the rock matrix from the waste package tests has not been completed, the solution data provide a framework with which to examine some implied hydrothermal controls. Figure 21 is a stability diagram for some of the principal alkali aluminosilicate minerals calculated by Browne and Ellis 1970, in terms of alkali/hydrogen ion activity ratios. Solution data for the Broadlands area (not shown) generally clusters near the feldspar field. With decreasing $\mathrm{CO}_{2}$ and temperature, $\mathrm{K}$-feldspar is a common alteration mineral under these conditions. Solution data expressed as molar units from the direct sampling waste package tests are plotted on Figure 21 from their initial composition determined when the autoclave reached pressure and temperature up to their composition determined in solutions extracted at $4 \mathrm{wk}$. 
TABLE 14. Comparison of Three Week Waste Package Compositions With Geothermal Solution Compositions from Similar Rock Types and Temperature. $\mu \mathrm{g} / \mathrm{ml}$ Geothermal Data from Ellis 1979

\begin{tabular}{|c|c|c|c|c|c|c|c|c|}
\hline & Temp ${ }^{\circ} \mathrm{C}$ & $\begin{array}{c}\mathrm{pH} \\
\left(20^{\circ} \mathrm{C}\right) \\
\end{array}$ & $\mathrm{Na}$ & $K$ & $\mathrm{Ca}$ & $\mathrm{SiO}_{2}$ & $\underline{\mathrm{SO}}_{4}$ & $\mathrm{CO}$ \\
\hline Granite & 250 & 8.4 & 108 & 12.7 & 0.5 & 408 & 25.4 & 138 \\
\hline Basalt & 250 & 7.9 & 127 & 52.6 & 1.03 & 984 & 40.2 & 80 \\
\hline $\begin{array}{l}\text { Broadlands } \\
\text { (Rhyolite/Graywacke) }\end{array}$ & 260 & 8.6 & 980 & 200 & 2.4 & 750 & 6.5 & 117 \\
\hline $\begin{array}{l}\text { Wairakei } \\
\text { (Rhyolite/Andesite) }\end{array}$ & 255 & 8.4 & 1320 & 225 & 17 & 690 & 36 & 19 \\
\hline
\end{tabular}

The evolution of these solutions seems to follow the boundary between the albite and K-feldspar stability fields which can be represented by

$$
\mathrm{NaALSi}_{3} \mathrm{O}_{8}+\mathrm{K}^{+}=\mathrm{KALSi}_{3} \mathrm{O}_{8}+\mathrm{Na}^{+}
$$

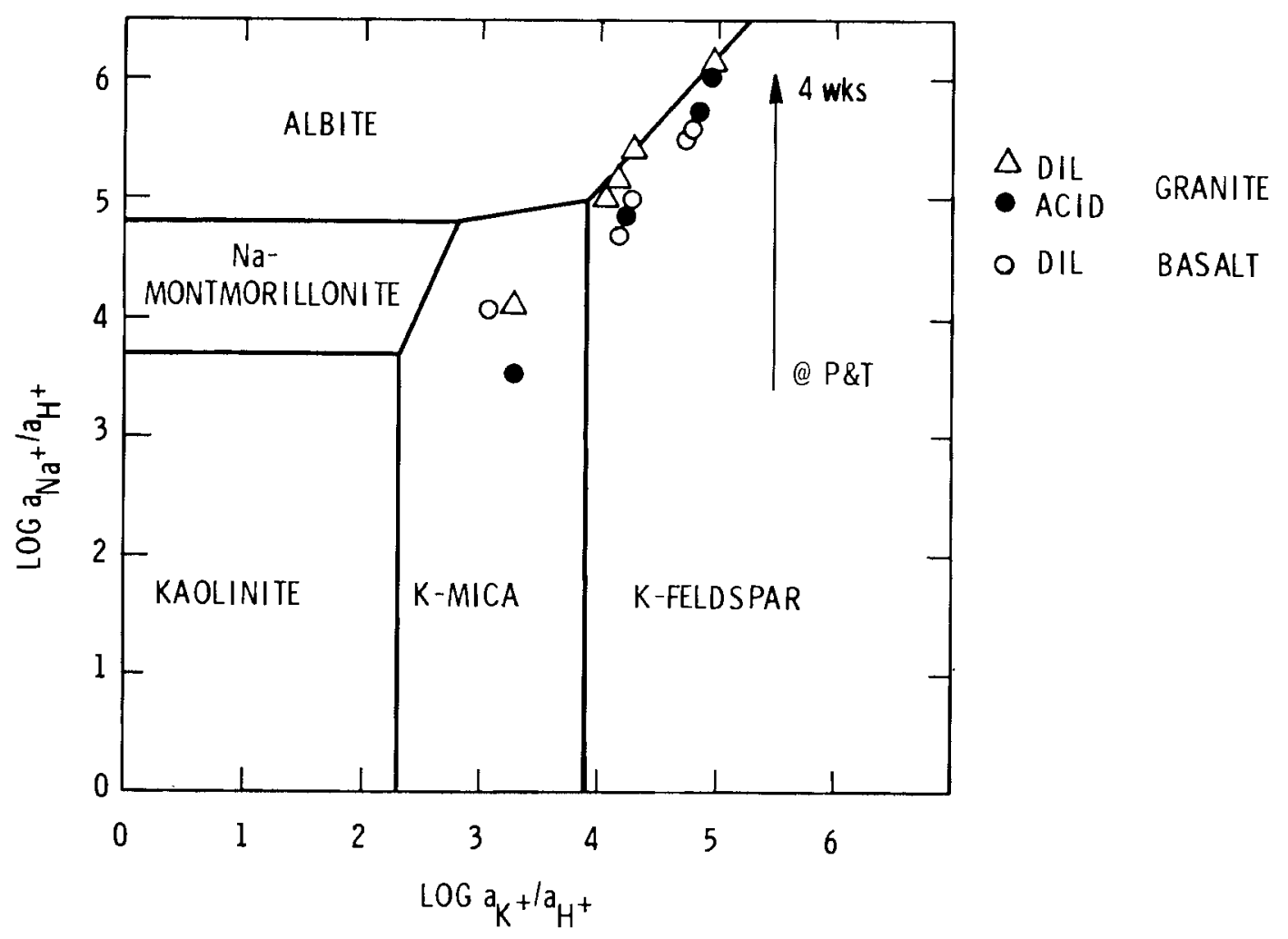

FIGURE 21. Stability Diagram for Selected Alkali Minerals in Terms of $\mathrm{aNa}^{+} / \mathrm{aH}^{+}$ and $\mathrm{aK}^{+} / \mathrm{aH}^{+}$activity ratios at $260^{\circ} \mathrm{C}$. (From Browne and Ellis 1970.) 
which suggests that the $\mathrm{K}^{+}$and $\mathrm{Na}^{+}$ion concentrations are controlled by feldspar equilibria. It should be emphasized that the diagram is calculated at a specified temperature using only the pure mineral phases shown and assumes thermodynamic equilbrium. When applied to complex rock systems, an exact fit may or may not be expected, but such calculated equilbria serve as a useful guide for identification of possible controlling reactions.

Solution data for $\mathrm{Ca}^{++}$and $\mathrm{K}^{+}$ions from the package tests are plotted in Figure 22 which is the stability diagram for these minerals calculated at $260^{\circ} \mathrm{C}$ by Ellis 1970 . The evolutionary trend of these solutions follows the boundary between zoisite and K-feldspar which can be represented by

$$
\mathrm{Ca}_{2} \mathrm{AL}_{3}\left(\mathrm{SiO}_{4}\right)_{3}(\mathrm{OH})+3 \mathrm{~K}^{+}+\mathrm{H}^{+}+6 \mathrm{SiO}_{2}=3 \mathrm{KALSi}_{3} \mathrm{O}_{8}+2 \mathrm{Ca}^{++}+\mathrm{H}_{2} \mathrm{O} \text {. }
$$

At a first approximation, the data suggest that zoisite $\left[\mathrm{Ca}_{2} \mathrm{Al}_{3} \mathrm{Si}_{3} \mathrm{O}_{12}\right.$ $(\mathrm{OH})$ ] should be forming in the package systems as an alteration product. As pointed out by Ellis 1979, and Ghent 1979, the stability of zoisite is in part dependent on the available dissolved $\mathrm{CO}_{2}$. At high $\mathrm{CO}_{2}$ pressures, calcite

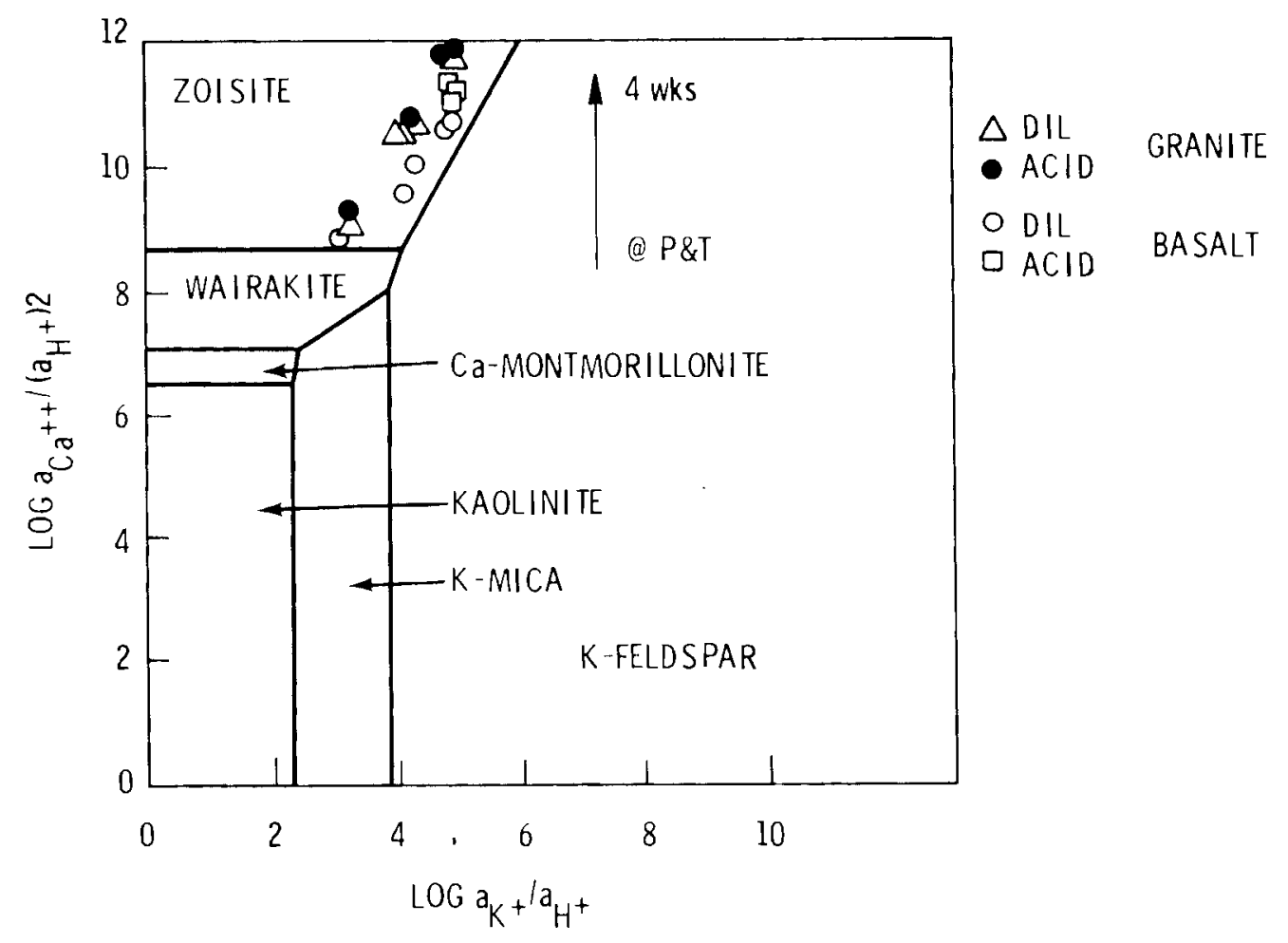

FIGURE 22. Stability Diagram for Selected Potassium and Calcium Alteration Minerals in Terms of $\mathrm{aCa}^{++} /\left(\mathrm{aH}^{+}\right)^{2}$ and $\mathrm{aK}^{+} / \mathrm{aH}^{+}$activity Ratios. (Modifed from Ellis 1970.) 
$\left(\mathrm{CaCO}_{3}\right)$ precipitates, precluding zoisite crystallization. As shown by Ellis $1970 \mathrm{~b}$, this has resulted in K-feldspar alteration at Broadlands which has high dissolved $\mathrm{CO}_{2}$, but zoisite alteration at Wairakei with $\mathrm{low}_{2} \mathrm{CO}_{2}$. The dissolved $\mathrm{CO}_{2}$ based on $\mathrm{HCO}_{3}$ concentrations in solutions from both package tests is similar to the Broadlands composition so $\mathrm{K}$-feldspar alteration might be expected in granite and basalt waste interactions. 
CONCLUSIONS

It is premature to make definite conclusions from these initial waste package tests but some directions that may lead to the development of source term models are indicated. These tests suggest that the release rates of some of the most mobile waste-form elements such as Mo and $B$ are not inhibited by the presence of crystalline rock but that their release in brine solution may be effected by ionic strength. The release of Cs may be retarded by crystalline rock equilibria because of the presence of aluminosilicate components that contribute to secondary phase development. This is not apparent in brine solutions. The solution composition of components common to both the waste form and rock seems to be controlled by rock-water interactions with the contribution of the waste form exhibiting an unknown minor effect. The role of secondary mineralization as a sink or element mobility retardent deserves further investigation. It does not appear that simple solubility studies of these minerals will yield expected solution concentrations of their elemental constituents under repository conditions. A more realistic approach suggests that the secondary mineral-host rock mineral assemblage, examined as a system, may be closer to repository conditions. Hypothetically, reactions of the type:

$2 \mathrm{CsAl} \mathrm{Si} 2 \mathrm{O}_{6}+\mathrm{H}_{2} \mathrm{O}+\mathrm{H}^{+}=\mathrm{Al}_{2} \mathrm{Si}_{2} \mathrm{O}_{5}(\mathrm{OH})_{4}+25 \mathrm{iO}_{2}+2 \mathrm{Cs}$ may control solute concentrations.

The results of these first package tests indicate that the effects of redox conditions, whether influenced by temperature, radiolysis, or both, need more emphasis, and emphasis should be placed on methods of redox potential measurement. If the uranium in 76-68 glass can be considered a crude analog for the other actinides then its relative mobility by dissolution under oxidizing conditions in closed systems compared with transport by diffusion deserves more study.

The similarties between the results from the package tests and geothermal studies is encouraging because it suggests that some of the geothermal model development may be adaptable to repository conditions. 


\section{REFERENCES}

Additon, M. K., and R. 0. Seil. 1979. Columbia River Basalt Reference Samples, Rockwell Hanford Operations. RHO-SA-93, Rockwell Hanford Operations, Richland, Washington 99352.

Ames, L. L. 1978. Controlled Sample Program Publication No. 1, Characterization of Rock Samples; PNL-2797, Pacific Northwest Laboratory, Richland, Washington.

Bradley, D. J., C. 0. Harvey, and R. P. Turcotte. 1979. Leaching of Actinides and Technecium from Simulated High Level Waste Glasss. PNL-3152, Battelle Pacific Northwest Laboratory, Richland, Washington 99352.

Bradley, D. J., G. L. McVay, and D. G. Coles. 1980. Leach Test Methodology for the Waste/Rock Interactions Technology Programs. PNL-3326, Battelle Pacific Northwest Laboratory, Richland, Washington 99352.

Bredehoeft, J. D. 1978. "Geologic Disposal of High-Level Radioactive WastesEarth Science Perspectures." Geological Survey Circuler 779.

Browne, P. R. L., and A. J. Ellis. 1970. "The Chaki-Broadlands Hydrothermal Area, New Zealand: Mineralogy and Related Geochemistry." Am. Jour. Sic., V. 269 , p. 97-131.

deMarsily, G. 1977. "Nuclear Waste Disposal: Can the Geologist Guarantee Isolation?." Science, V. 197, p. 4303.

Ellis, A. J. 1970. "Chemical Processes in Hydrothermal Systems" - A Review, in Proc. Symp. Hydrogeochemistry and Biogeochemistry. V. 1, Washington D.C.: The Clarke Co. (Published 1973), p. 1-26.

Ellis, A. J. 1979. "Explored Geothermal Systems," in Barnes, ed. Geochemistry of Hydrothermal One Deposits, 2nd ed., John Wiley \& Sons, p. 632-683.

Environmental Protection Agency. "State of Geological Knowledge Regarding Potential Transport of High-Level Radioactive Waste from Deep Continental Repositories." Report of an ad Hoc Panel of Earth Scientists, EPA/520/4-78/004.

Flanagan, F. J. 1973. "1971 Values for International Geochemical Reference Samples." Geochim. et. Gesmochim Acta, V. 37, p. 1189-1200.

Ghent, E.D. 1979. "Problems in Zeolite Facies Geothermometry, Geobarometry, and Fluid Compositons." SEPM Special Publication No. 26, p. 81-87. 
Greenwood, H. J. 1961. "The System NaAlSi2 $0_{8}-\mathrm{H}_{2} \mathrm{O}$ Argon: Total Pressure and Water Pressure in Metamorphism." Jour. of Geophys. Res., V 66, p. 3923-3946.

Holland, H. D., and S. D. Malinin. 1979. "The Solubility and Occurrence of Non-One Minerals." in Barnes ed. Geochemistry of Hydrothermal One Deposits, 2nd ed., John Wiley \& Sons, p. 461-508.

Katayama, Y. B. 1979. Spent LWR Fuel Leach Tests. PNL-2982, Battelle Pacific Northwest Laboratory, Richland, Washington 99352.

Katayama, Y. B., D. J. Bradley, and C. 0. Harvey. 1979. Status Report on LWR Spent Fuel IAEA Tests. PNL-3173, Battelle Pacific Northwest Laboratory, Richland, Washington 99352.

Komanreni, S., B. E. Scheetz, G. J. McCarthy, W. E. Coons. 1980. Hydrothermal Interactions of Cesium and Strontium Phases, From Spent Unreprocessed Fuel with Basalt Phases and Basalts. RH0-BWI-C-70, Rockwe11 Hanford Operations, Richland, Washington 99352.

Lambert, S. J. 1980. Mineralogical Aspects of Fluid Migration in the Salt Block II Experiment. SAND79-2423, Sandia National Laboratories, Albuquerque, New Mexico.

McCarthy, G. J., W.B., White, R. Roy, B. E. Scheetz, S. Komarneni, D. K. Smith, and D. M. Ray. 1978. "Interactions Between Nuclear Waste and Surround ing Rock," Nature, V. 273, p. 217-219.

Westsik, J. H. Jr., and C. 0. Harvey. 1980. High Temperatue Leaching of a Simulated High Level Waste Glass. PNL-3172, Battelle Pacific Northwest Laboratory, Richland, Washgington 99352. 
APPENDIX A 
APPENDIX A

Figure A.1 thru A.3. 03TS, 03KS, and 06KS.

These are representative areas of waste package tests conducted using a salt matrix. 03T5 is the canister surface from a digestion bomb test, and the other two are from direct sampling autoclave tests. Both $\mathrm{NaCl}$ and silica precipitation are evident. Other phases include a calcium sulphate, probably gypsum $\left(\mathrm{Ca} \mathrm{SO}_{4} 2 \mathrm{H}_{2} \mathrm{O}\right.$ ), a potassium sulfate, and a phase with $\mathrm{Ca}-\mathrm{Mg}-\mathrm{S}-\mathrm{Si}-\mathrm{Cl}$ which may in fact be a polyphase material.

Figures A.4 thru A.7. 01TG, 02TB, and 04KB.

These surfaces are from digestion bomb tests using granite and basalt matrices respectively. The cubic crystals containing primarily $\mathrm{Ca}$ have a flourite $\left(\mathrm{CaF}_{2}\right)$ habit. If they are flourite, the source of flourine is a question. They were found only in granite matrix runs, not in basalt. The fluorine content of solutions of both basalt and granite runs were similar as were solutions from the large autoclave runs. This suggests that the source of flourine may be from the granite rather than from the Teflon liners. Other phases include amorphous-appearing material with both a spherical and honeycomb habit and particles of Ru, and Ru-Pd-Mo-Si. Ru and Ru-Pd metallic phases occur in 76-68 glass and these may have recrystallized.

Figure A.10. 05KG, 07TG, and 08TB.

The amorphous-appearing fibers in 05KG were observed on the surface of a granite matrix autoclave run and are primarily a Ca-Si-P material. The Si spectra may in fact be derived from underlying gel suggestions that the fibers themselves are a calcium phosphate. The other two runs are from digestion bombs with granite and basalt as the matrix. The zirconium silicate (Zircon?, $\mathrm{Zn} \mathrm{SiO}_{4}$ ) was observed on the granite matrix glass surface and the uranium bearing crystal appeared on the basalt matrix glass surface. 

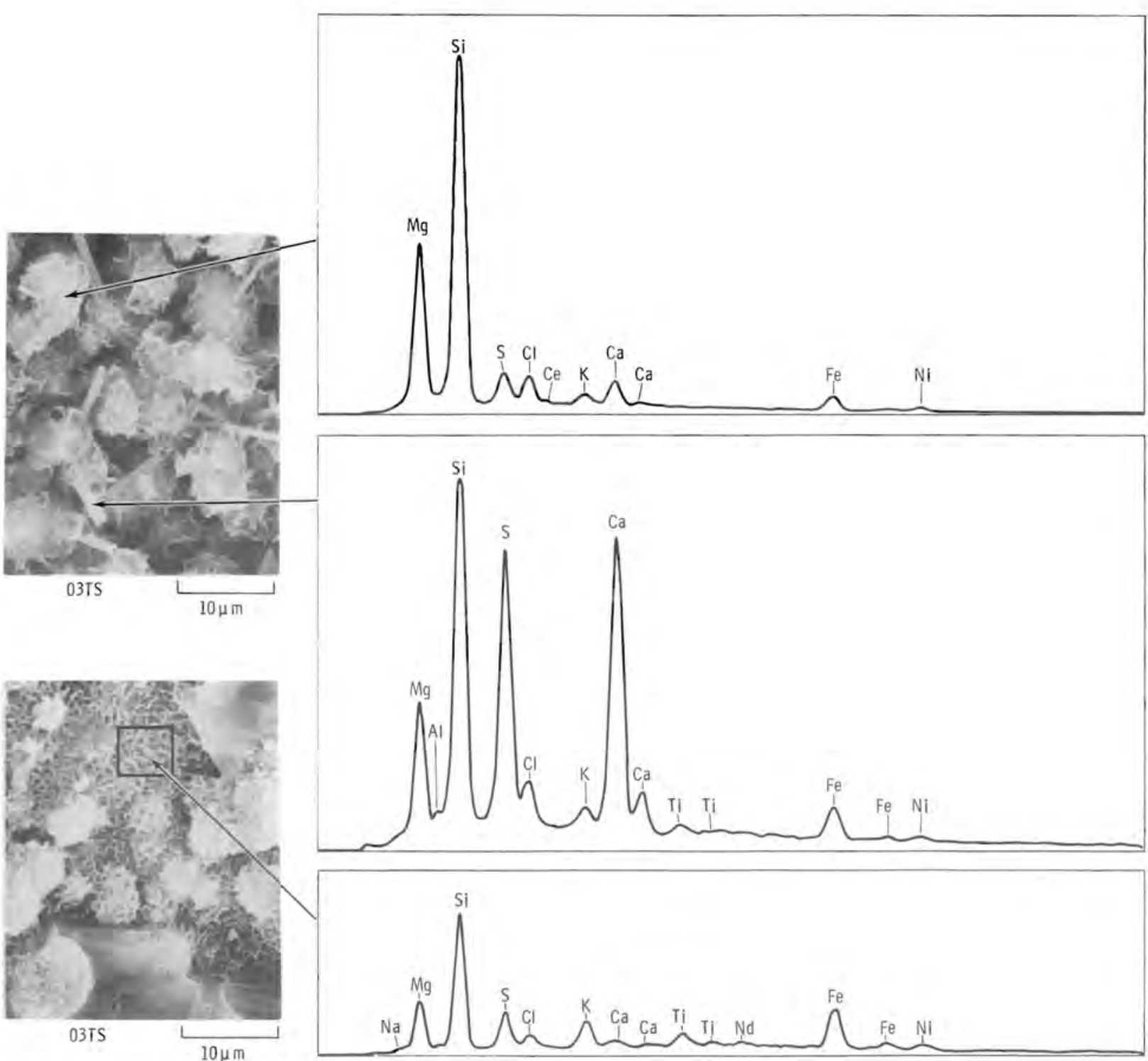

FIGURE A.1. Alteration Phases on the Glass Surface from Salt Package Digestion Bomb Tests Probably a Calcium Sulfate with Interference from Silica Gel. Polyhalite May Also Occur 


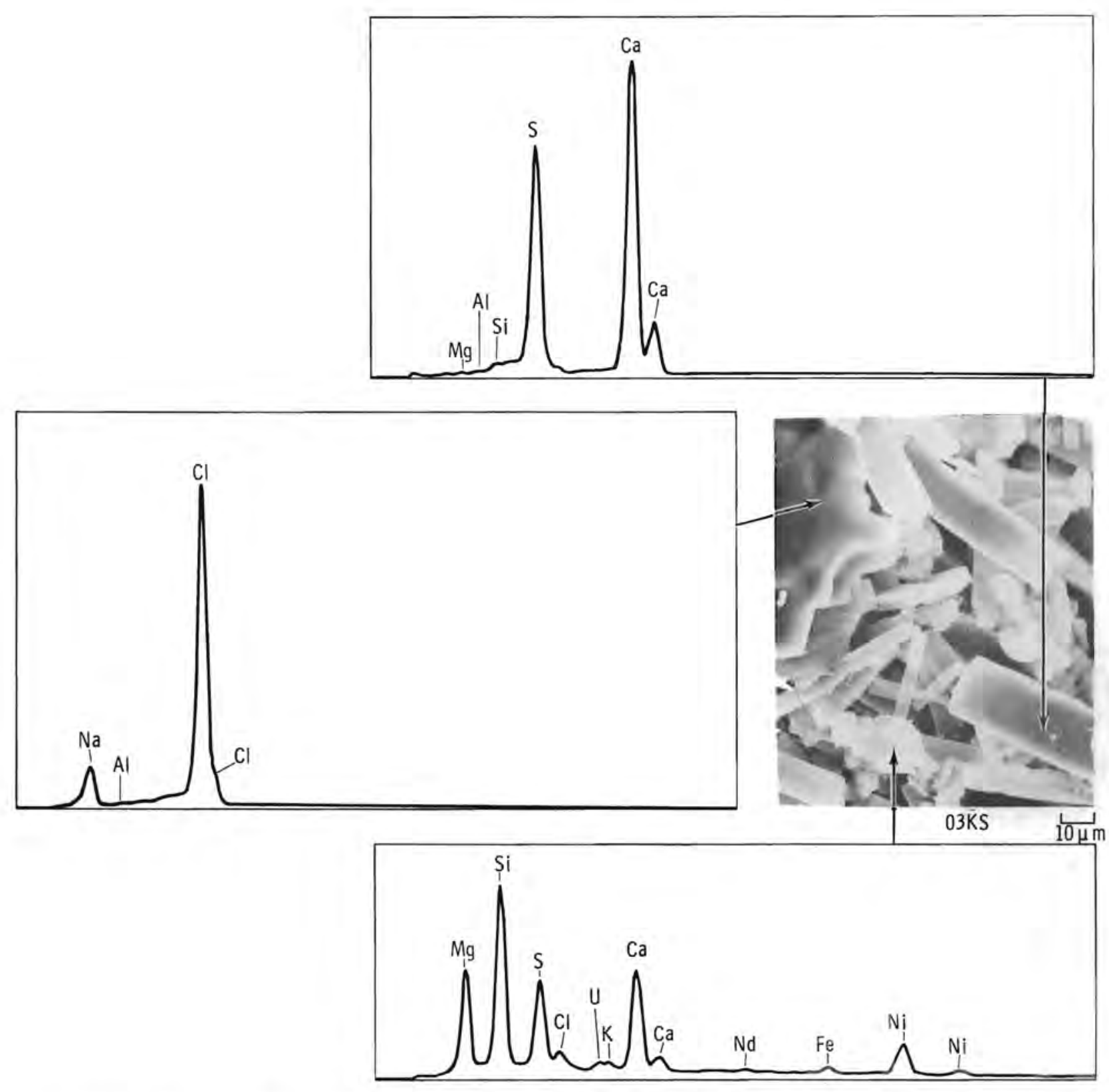

FIGURE A.2. Alteration Phases on the Glass Surface From Salt Package $850 \mathrm{ml}$ Autoclave Tests. The Dominant Phases are Calcium Sulfate, Sodium Chloride, Silicia Gel and Possibly Polyhalite 

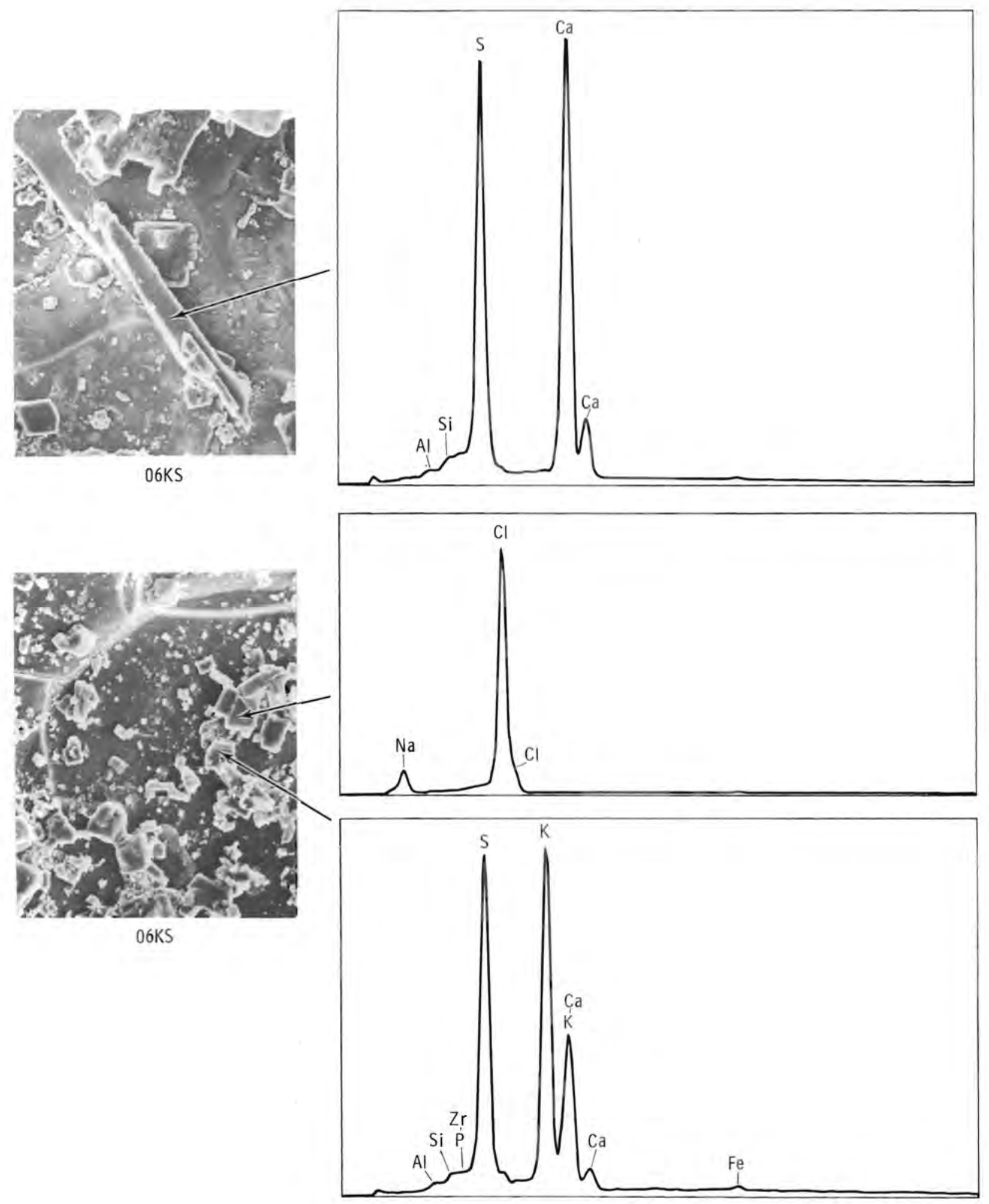

FIGURE A.3. Alteration Phases on the Glass Surface From Salt Package $850 \mathrm{ml}$ Autoclave Tests. Calcium and Potassium Sulfates are Present

$$
\text { A. } 4
$$




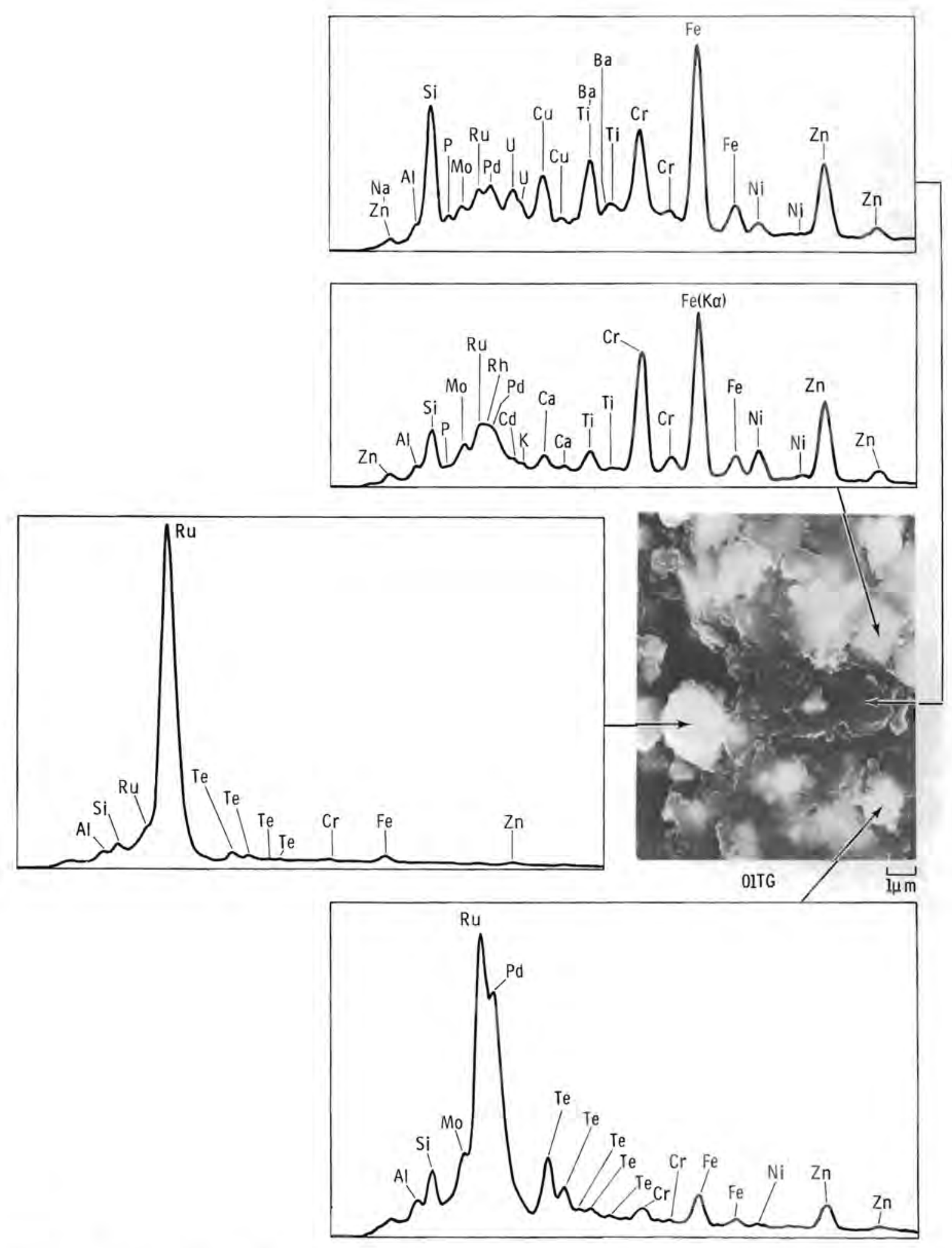

FIGURE A.4. Metal-Rich Phases on Glass Surface Near Canister Wall from Granite Package Digestion Bomb Test 


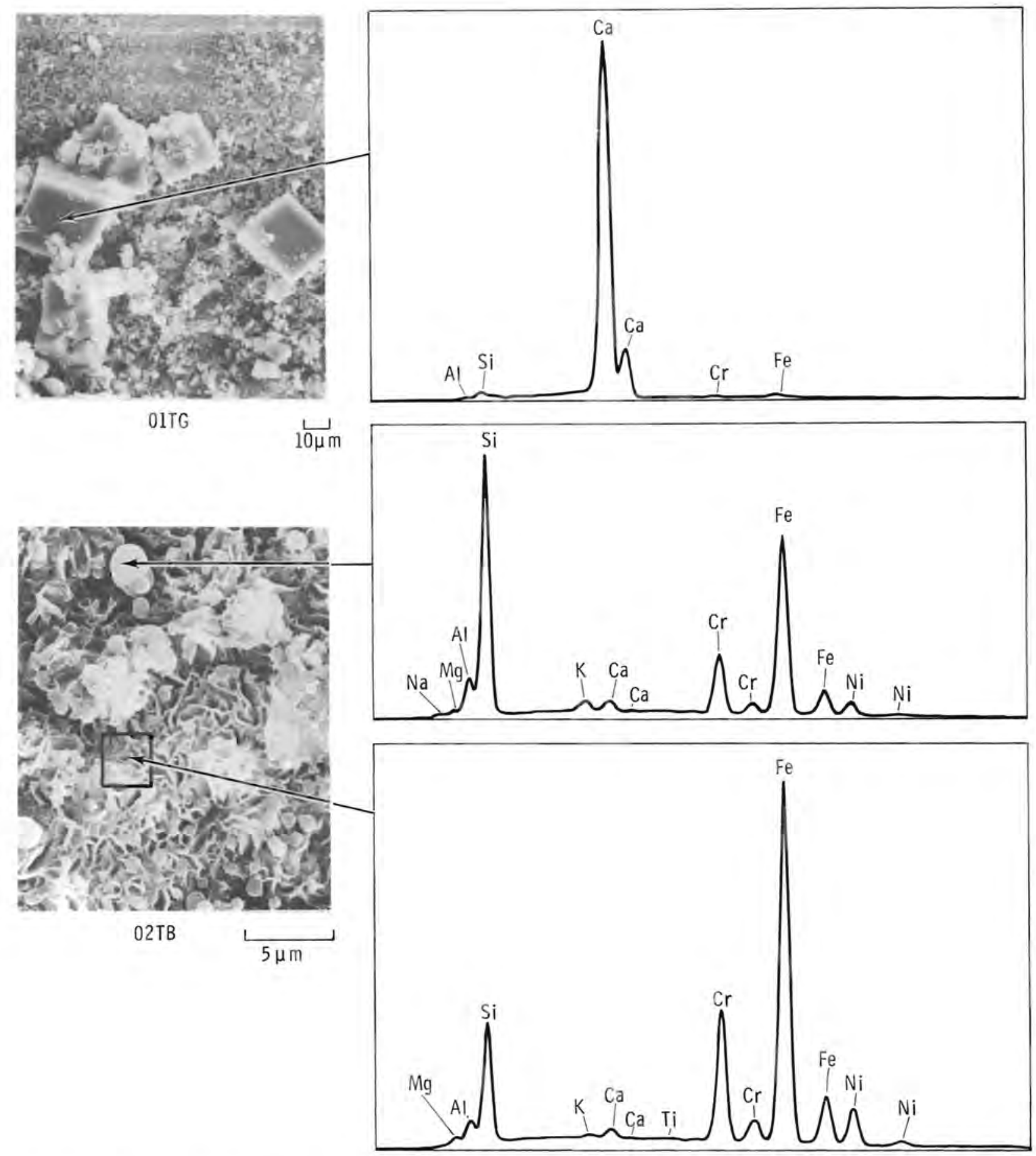

FIGURE A.5. Alteration Phases on Canister Rim From Granite (Upper) and Basalt (Lower) Digestion Bomb Tests. Ca-Rich Cubic Crystal May Be Fluorite, $\mathrm{Fe}$ and $\mathrm{Cr}$ Peaks are from Canister Below the Silica Gel Coating 


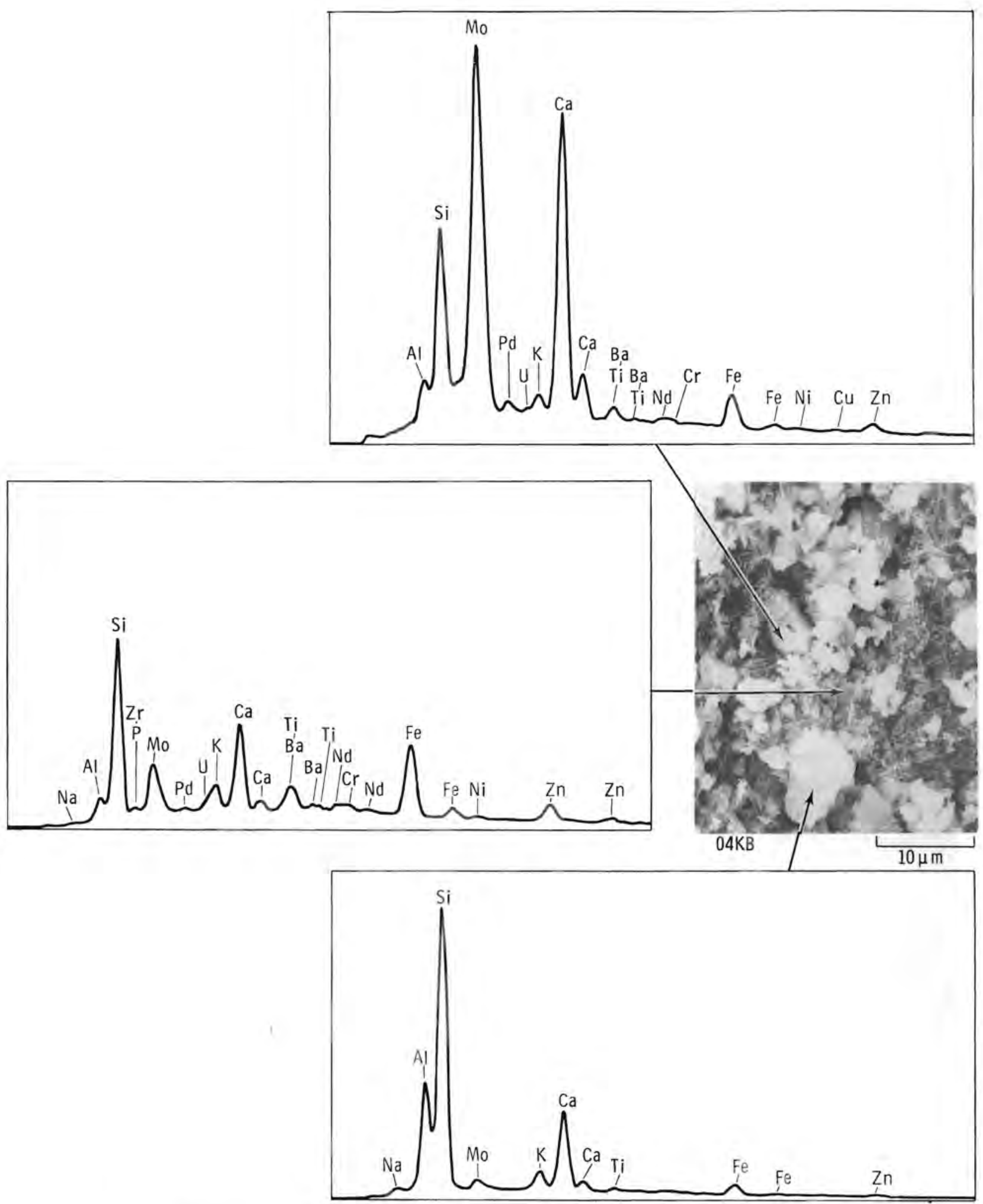

FIGURE A.6. Alteration Phases on Glass Surface from Basalt Package Autoclave Test 

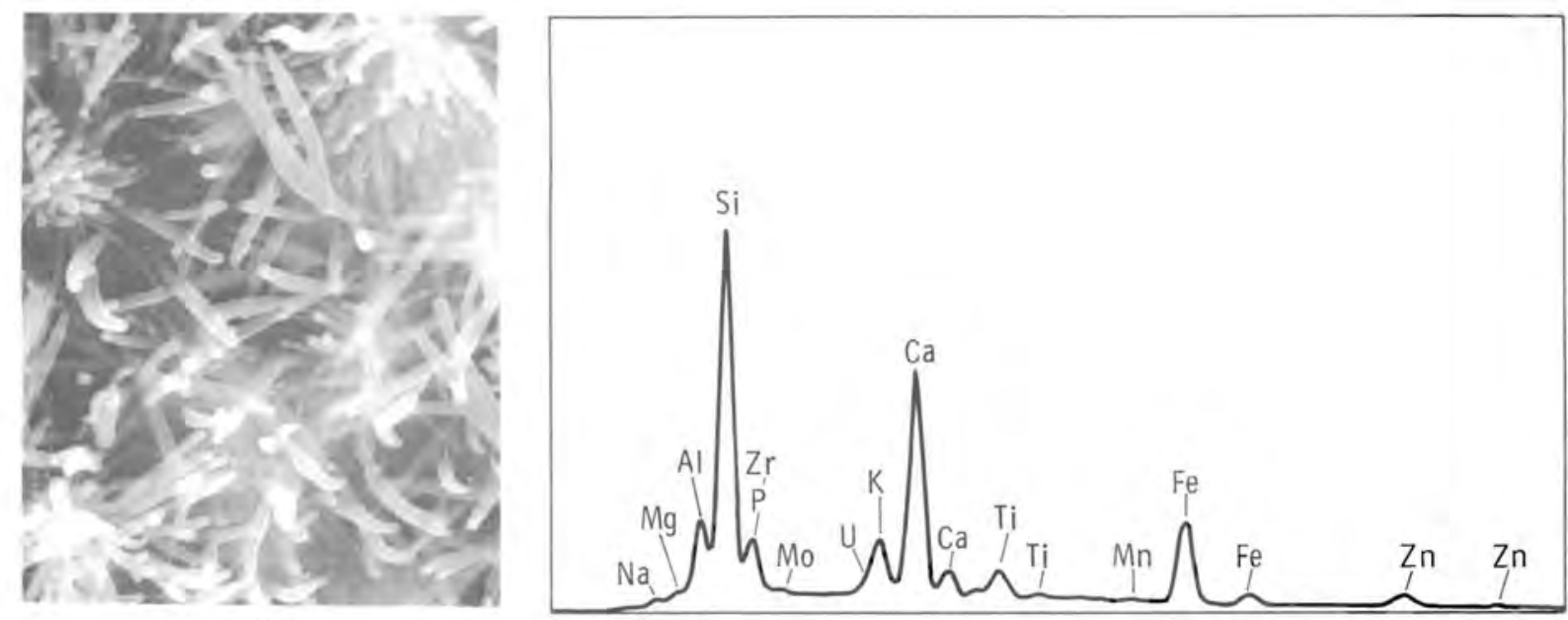

05KG
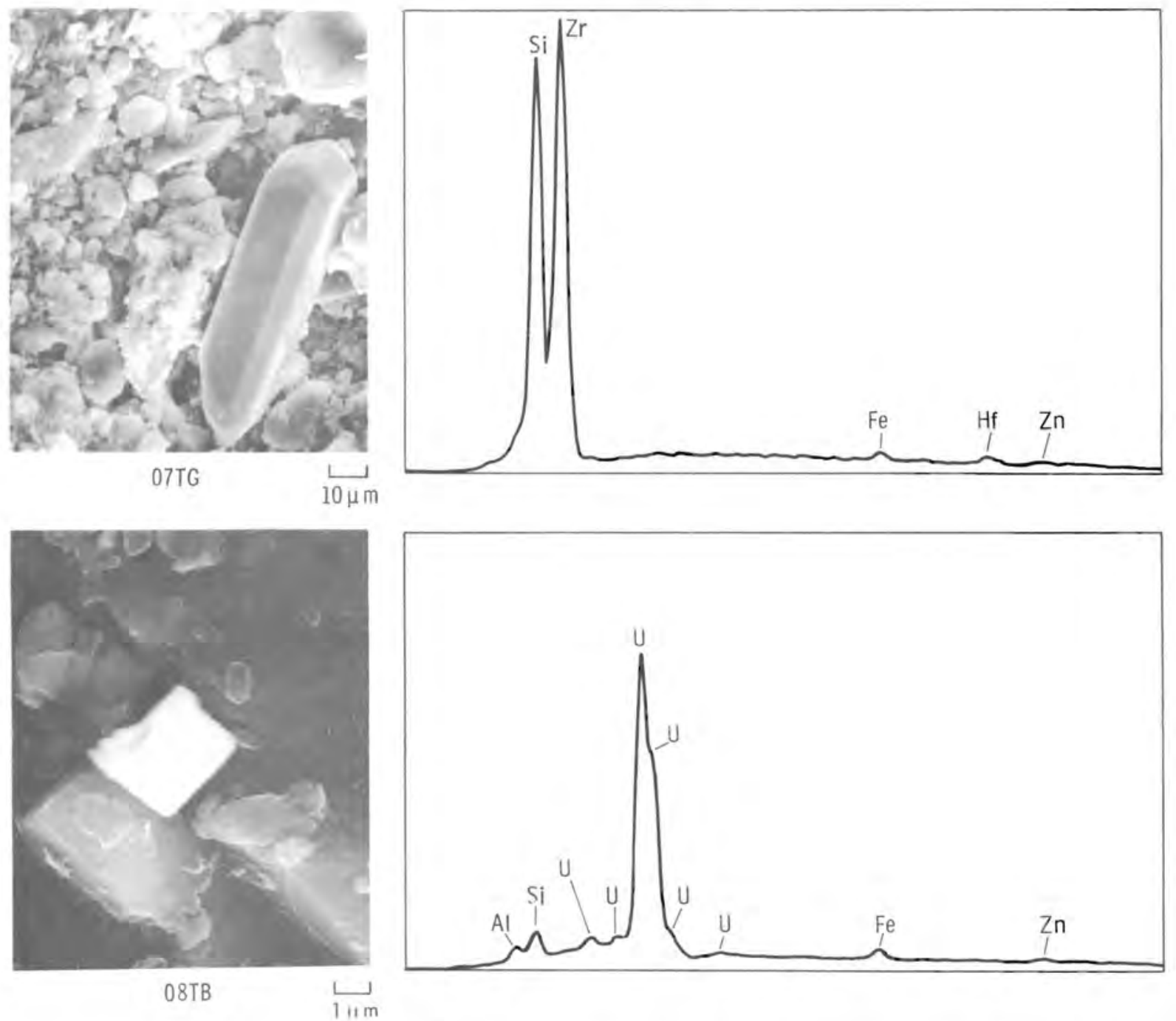

FIGURE A.7. Alteration Phases On Glass Surface from Granite Package Autoclave Test (Upper), Granite Package-Digestion Bomb (Middle), and Basalt Package-Digestion Bomb (Lower). The Spectra To Right Refer to the Crystals Shown 
APPENDIX B 
APPENDIX B

Figure B.1 is a series of XPS spectra from granite wafer surfaces from digestion bomb packages and spectra from the second series of autoclave tests in which the pressure was purposely lowered is shown in Figure B.2. A higher resolution of these spectra at -380 to $-400 \mathrm{eV}$ is shown adjacent to the survey spectra. Although there is some $\mathrm{K}$ interference at the $-386 \mathrm{eV}$ uranium peak, the second uranium peak at $-379 \mathrm{eV}$ clearly suggests that uranium has migrated in the autoclave test which was allowed to develop a vapor phase, but has not migrated significantly in the digestion bomb test which was probably in a relatively more reducing condition. Similar relationships are shown in the basalt package tests in Figure B.3 through B.5. Again it appears that uranium has migrated in the autoclave run, but not in the digestion bomb run. The lower spectra in Figure B. 3 is from the surface of a recrystallized salt pellet surface from the first series of direct sampling autoclave runs. No evidence for uranium migration was observed. 

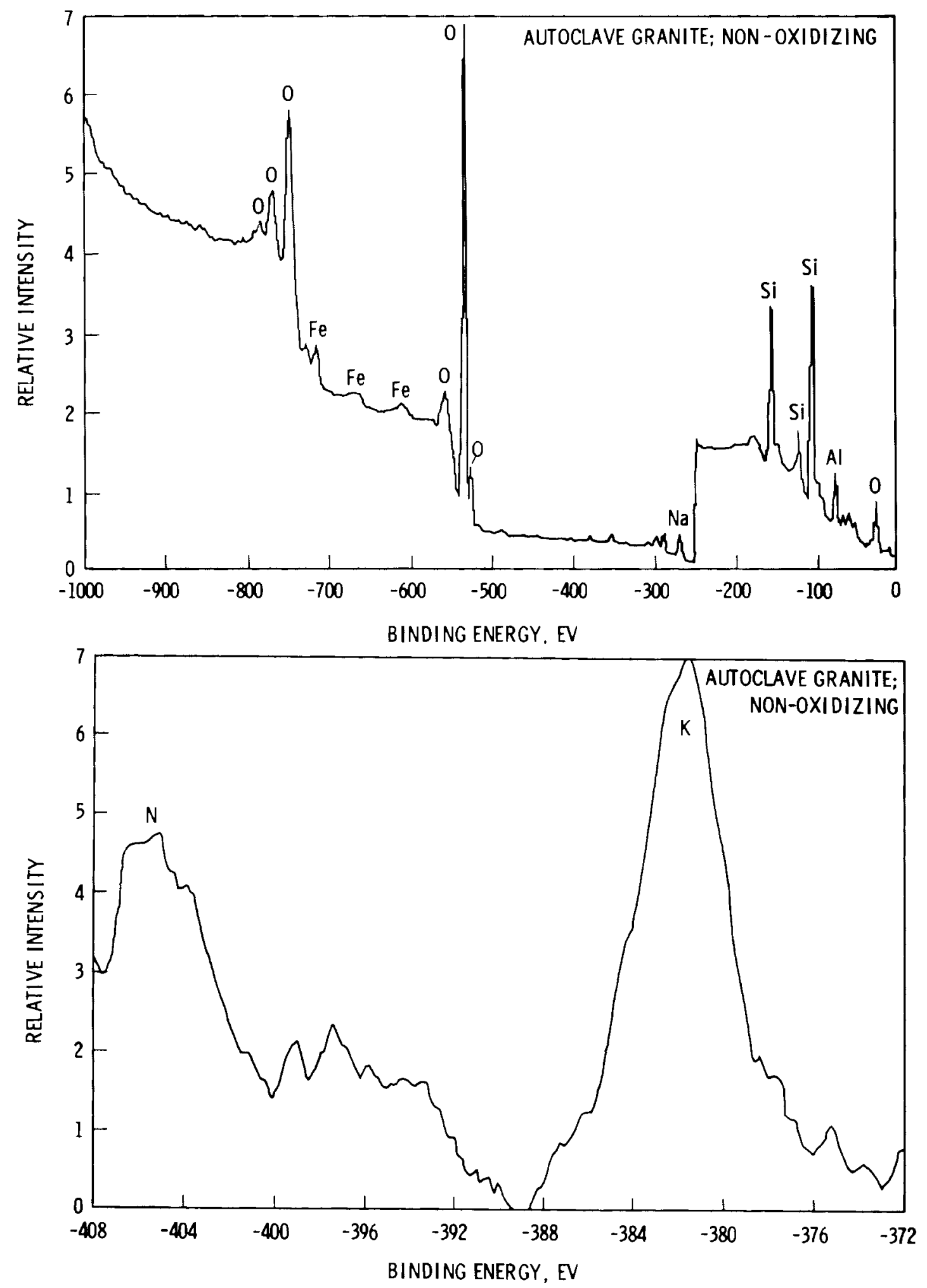

FIGURE B.1. XPS Spectra from Surface of Granite Pellet Run Submersed in Liquid Phase In Digestion Bomb Test. Lower Spectra is Shown in an Expanded Scale in the Vicinity of Uranium Peaks (-386eV and $-397 \mathrm{eV})$. No Evidence of Uranium Found on Surface

\section{B.2}



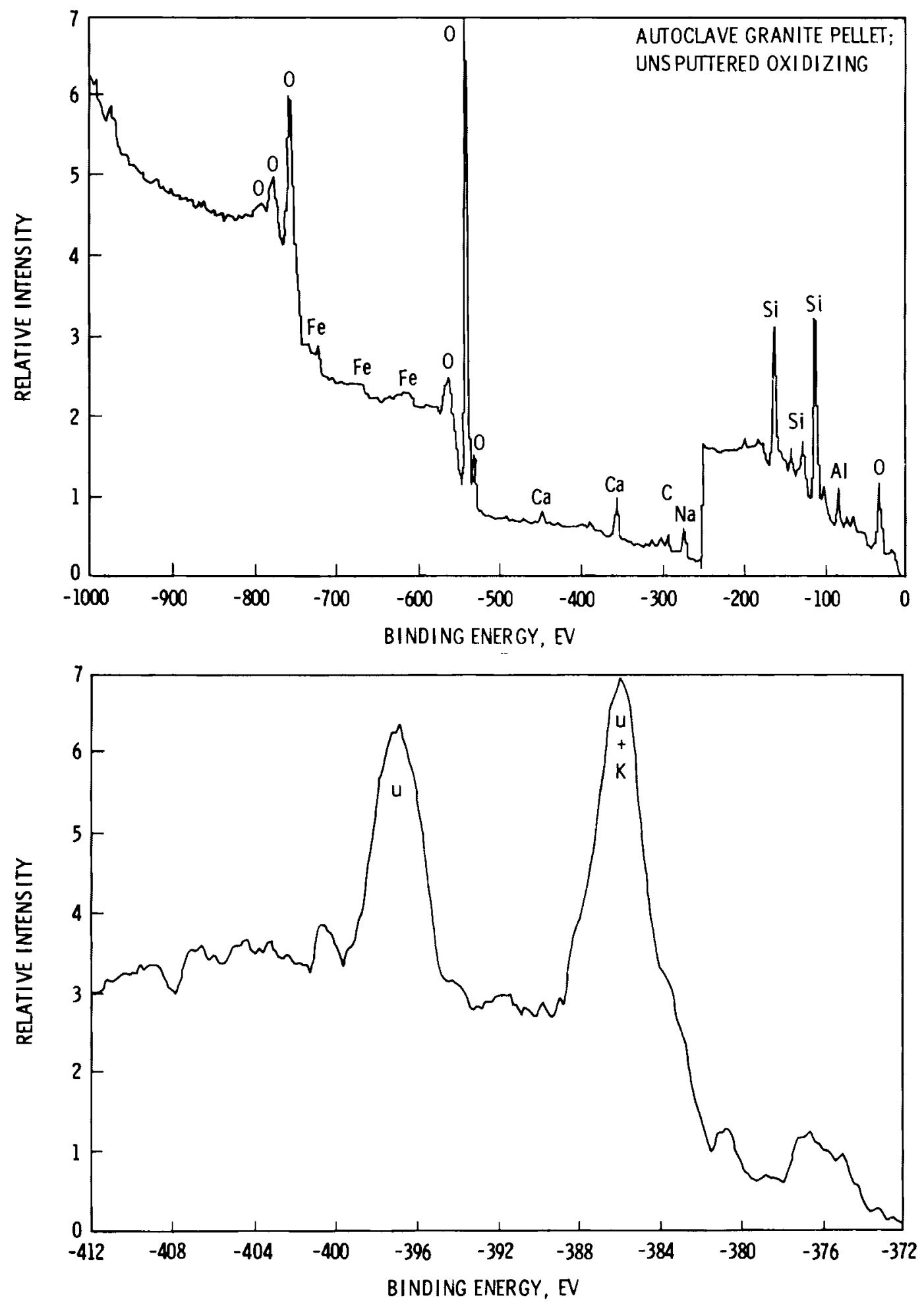

FIGURE B.2. XPS Spectra from Surface of Granite Pellet Exposed to a Vapor Phase in Autoclave Test. Compare with Figure B.1 and Note Presence of U Peaks 

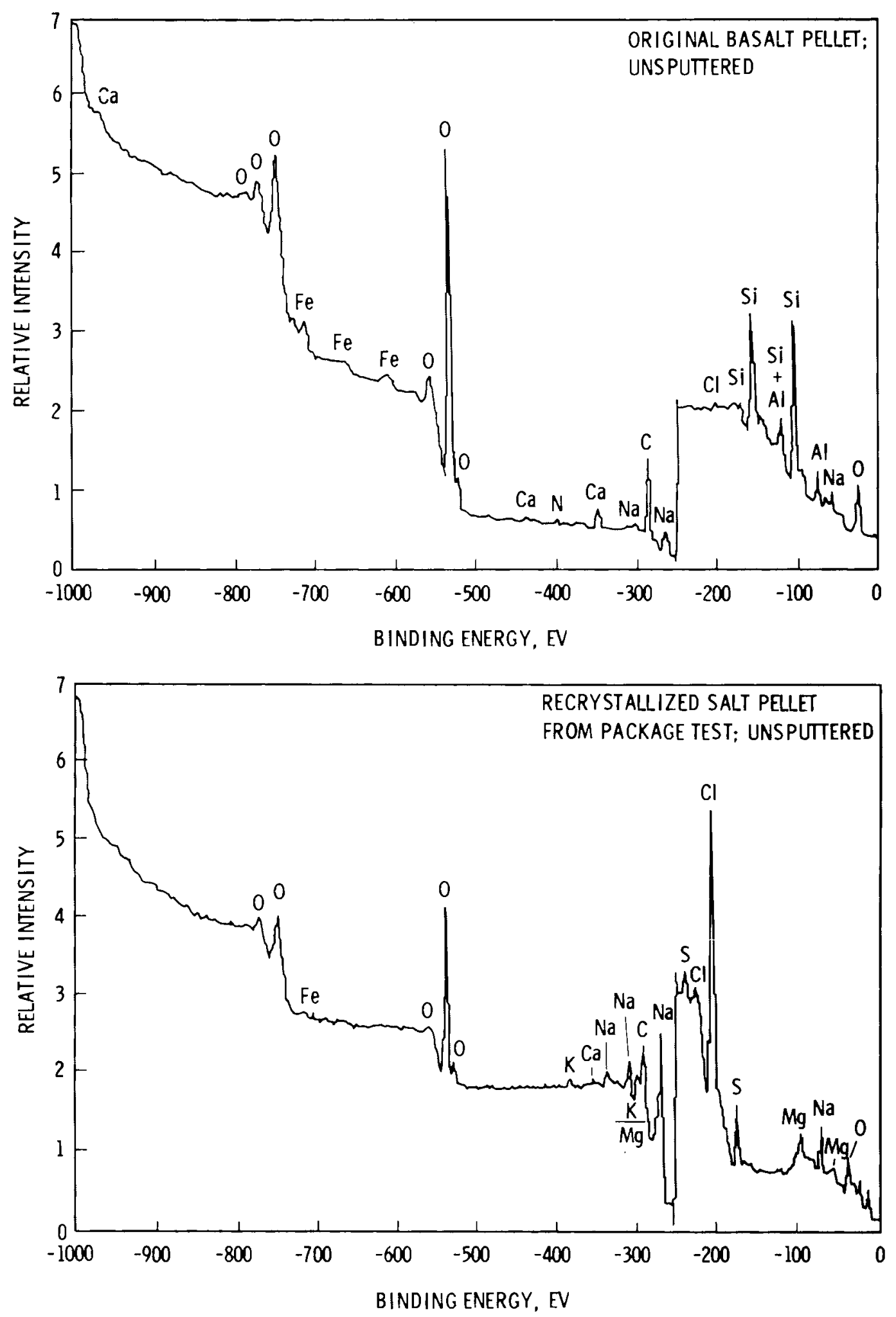

FIGURE B.3. XPS Spectra of Original Basalt Pellet (Upper) and Recrystallized Salt Pellet (Lower) Removed from a Salt Package Test 

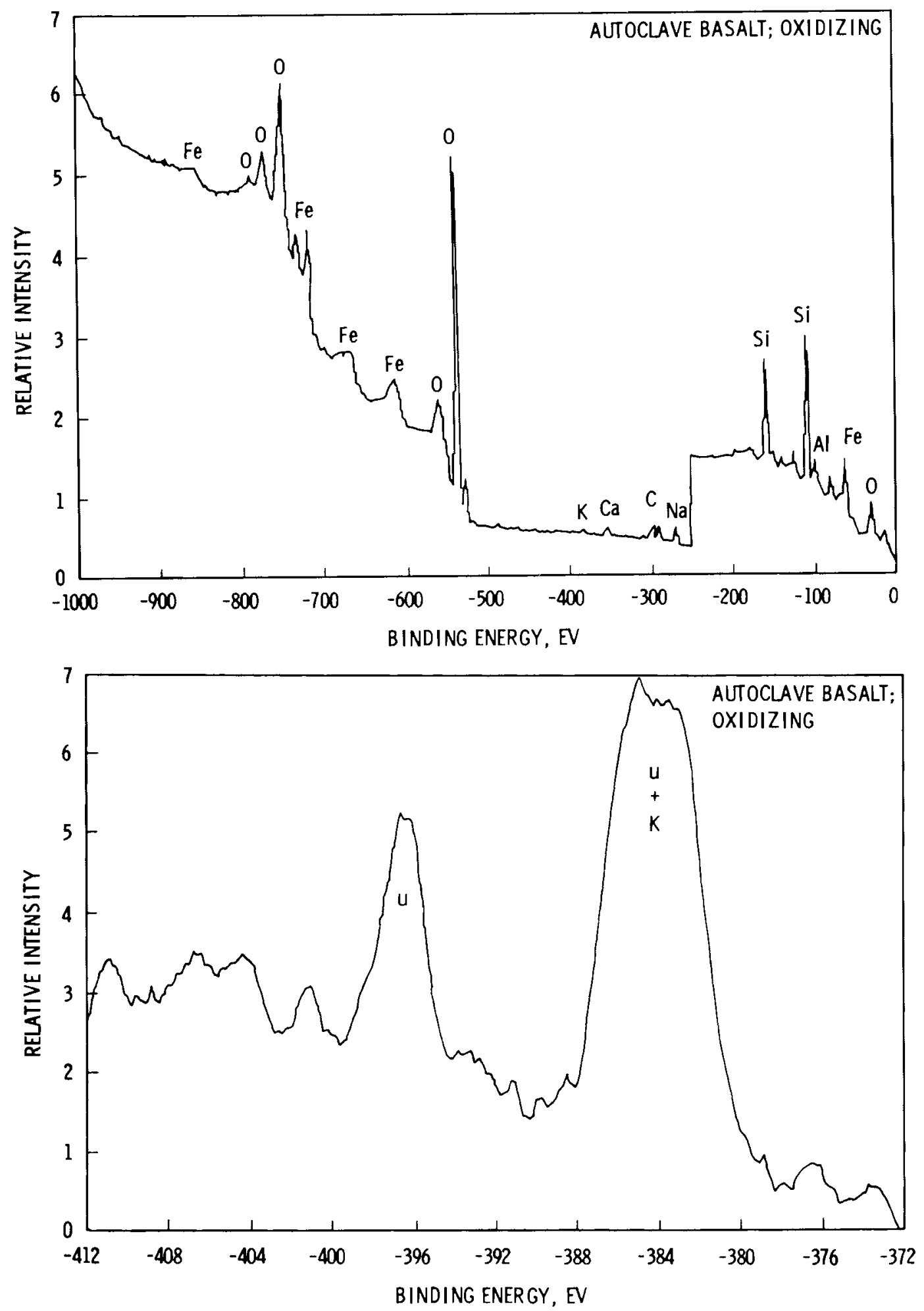

FIGURE B.4. XPS Spectra of Basalt Pellet Exposed to a Vapor Phase in a Package Test. Lower Spectra is an Expanded Scale in Vicinity of Uranium Peaks. Compare with Figure B.2 for Similar Occurrence in Granite Packages 

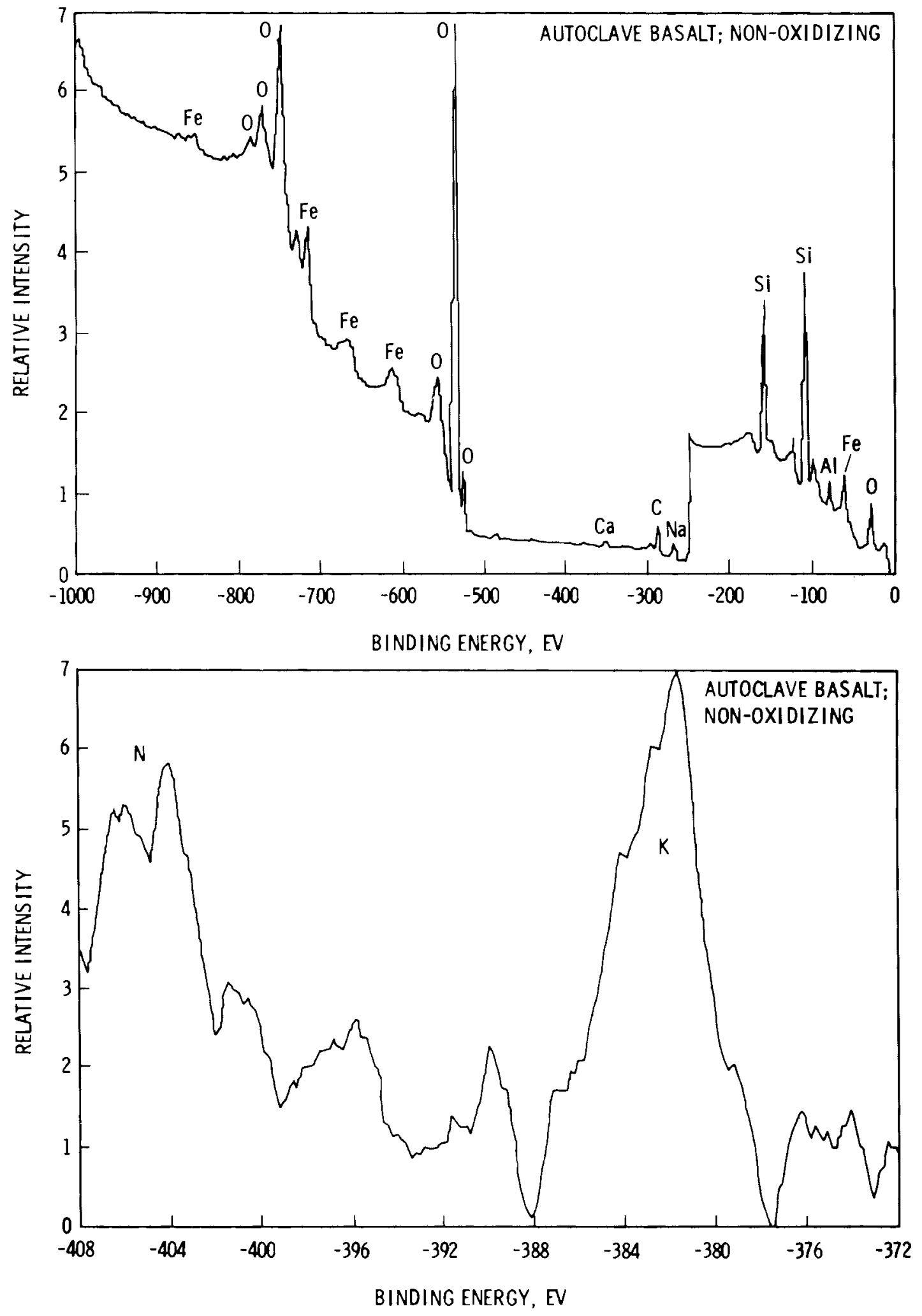

FIGURE B.5. XPS Spectra of a Basalt Pellet Run Submersed in a Liquid Phase in a Digestion Bomb Test. No Evidence of $U$ Found. Compare With Figure B.1 
No. of

Copies

OFFSITE

A. A. Churm

DOE Patent Division

9800 South Cass Avenue

Argonne, IL 60439

27 DOE Technical Information Center

Don Alexander

U.S. Nuclear Regulatory

Commission

MS 905-SS

High Level Waste Tech. Development

Washington, DC 20555

John A. Apps

Lawrence Berkeley Laboratory

University of California

One Cyclotron Road

Building 90/1140C

Berkeley, CA 94720

Argonne National Laboratory

Reference Library

9800 South Cass Avenue

Argonne, IL 60439

Dr. Randy L. Bassett

Bureau of Economic Geology University of Texas

University Station, Box $X$

Austin, TX 78712

10 Battelle Memorial Institute

Office of Nuclear Waste Isolation

505 King Avenue

Columbus, $\mathrm{OH} 43201$

Attn: Beverly Rawles
No. of

Copies

Gary Beall

Radian Corporation

8500 Shoal Creek

Aust in, TX 78766

Larry Benson

Lawrence Berkeley Laboratory

University of California

One Cyclotron Road

Building 90/1140G

Berkeley, CA 94720

J. R. Berreth

Exxon Nuclear

Idaho Corporation

P.0. Box 2800

Idaho Falls, ID 83401

George Birchard

Nuclear Regulatory Commission

Office of Nuclear Research

Mail Stop 1130-SS

Washington, DC 20555

J. 0. Blomeke

Union Carbide Corporation (ORNL)

Chemical Technology Division

P.0. Box $Y$

Oak Ridge, TN 37830

Ernest Bondietti

Environmental Sciences Division

Oak Ridge National Laboratory

B $7 d g .1505$

Oak Ridge, TN 37830

A. Brandstetter

Office of Nuclear Waste

Isolation

Battelle Memorial Institute

505 King Avenue

Columbus, $\mathrm{OH} 43201$

Distr.1 
No. of

Copies

Brookhaven National Laboratory

Reference Section

Information Division

Upton, Long Is land, NY 11973

Douglas G. Brookins

Department of Geology

University of New Mexico

Albuquerque, NM 87131

Harry C. Burkholder

Office of Nuclear Waste

Isolation

Battelle Memorial Institute

$505 \mathrm{King}$ Avenue

Columbus, $\mathrm{OH} 43201$

J. L. Burnett

Office of Basic Energy Sciences

U.S. DOE

Washington, DC 20545

H. Clyde Claiborne

Oak Ridge National Laboratory

P.0. Box $X$

Oak Ridge, TN 37830

Jess Cleveland

Denver Federal Center

U.S. Geological Survey

P.0. Box 25046

MS -412

Lakewood, CO 80225

David G. Coles

Lawrence Livermore Laboratory

University of California

P.0. Box 808

MS-L233

Livermore, CA 94550

Peter Colombo

Brookhaven National Laboratory

Nuclear Wate Management Group

Upton, NY 11973
No. of

Copies

J. L. Cranda11, Director

E. I. duPont DeNemours and Co.

Savannah River Laboratory

Aiken, SC 29801

Carl R. Cooley

Department of Energy

Divison of Waste Isolation

Washington, DC 20545

Ramesh Dayal

Dept. of Nuclear Energy

Brookhaven National Laboratory

Upton, NY 11973

H. Diamond

Argonne National Laboratory

9700 South Cass Avenue

Argonne, IL 60439

Les Dole

Oak Ridge National Laboratory

P.0. Box $X$

Oak Ridge, TN 37830

R. G. Dosch

Sandia Laboratories

Division 4512

Albuquerque, NM 87185

Jim 0. Duguid

Office of Nuclear Waste Isolation

Battelle Memorial Institute

$505 \mathrm{King}$ Avenue

Columbus, $\mathrm{OH} 43201$

Environmental Protection Agency

Office of Radiation Programs

Technical Assessment Division Aw559

Washington, DC 20460

Warren Eister

Department of Energy

Division of Waste Isolation

Washington, DC 20545 
Bruce R. Erdal

Los Alamos Scientific Laboratory

CNC-11, MS-514

Los Alamos, NM 87545

Sherman Fried

Argonne National Laboratory

9700 South Cass Avenue

Argonne, IL 60439

A. Friedman

Argonne National Laboratory

9700 South Cass Avenue

Argonne, IL 60439

Robert G. Garvin

E. I. duPont DeNumours Co.

Savannah River Laboratory

Aiken, SC 29801

H. W. Godbee

Uniton Carbide Corporation (ORNL)

Chemical Technology Division

P.0. Box Y

Oak Ridge, TN 37830

Richard L. Hahn

Oak Ridge National Laboratory

P.0. Box $X$

Oak Ridge, TN 37830

R. J. Hall

Office of Nuclear Waste Isolation

Battelle Memorial Institute

$505 \mathrm{King}$ Avenue

Columbus, $\mathrm{OH} 43201$

Mark Harwe 11

P.0. Box 667

Canon Beach, OR 97110

Colin A. Heath

DOE Division of Waste Isolation

Washington, DC 20545
Larry L. Hench

Dept. of Materials Science and Engineering

University of FLorida

Gainesville, FL 32611

Norman Hubbard

Office of Nuclear Waste Isolation

Battelle Memorial Institute

$505 \mathrm{King}$ Avenue

Columbus, $\mathrm{OH} 43201$

Dana Isherwood

Lawrence Livermore Laboratory

P.0. Box 808

MS L-224

Livermore, CA 94550

J. L. Jardine

Argonne National Laboratory

9700 South Cass Avenue

Argonne, IL 60439

Doug Karim

Argonne National Laboratory

9700 South Cass Avenue

Argonne, IL 60439

I. A. Kilinic

Dept. of Geology

University of Cincinnati

Cincinnati, Ohio 45221

John F. Kircher

Office of Nuclear Waste Isolation

Battelle Memorial Institute

505 King Avenue

Columbus, $\mathrm{OH} 43201$

Kurt Kraus

Oak Ridge National Laboratory

110 Ogontz Lane

Oak Ridge, TN 37830 
No. of

Copies

R. B. Laughon

Office of Nuclear Waste Isolation

Battelle Memorial Institute 505 King Avenue

Columbus, $\mathrm{OH} 43201$

Lawrence Berkeley Laboratory

Reference Library

University of California

Berkeley, CA 94720

Lawrence Livermore Laboratory

Reference Library

P.0. Box 808

Livermore, CA 94550

Stan E. Logan

Los Alamos Tehnical Associates, Inc.

P.0. Box 410

Los Alamos, NM 87544

Tom Longo

Department of Energy

Division of Waste Isolation

Washington, DC 20545

Los Alamos Scientific Laboratory

Reference Library

P.0. Box 1663

Los Alamos, NM 87544

D. Lam

Argonne National Laboratory

9700 South Cass Avenue

Argonne, IL 60439

Richard W. Lynch

Manager, Department 4530

Sandia Laboratories

P.0 Box 5800

Albuquerque, NM 87185

I. Wende 11 Marine

E. I. du Pont de Nemours Co.

Savannah River Laboratory

Aiken, SC 29801
No. of

Copies

\author{
J. B. Martin \\ Asst. Director for Radioactive \\ Waste Mgmt. Branch \\ NRC Division of Materials and \\ Fuel Cycle Facility Licensing \\ Washington, DC 20555 \\ Jeff $L$. Means \\ Battelle Columbus Laboratory \\ 505 King Avenue \\ Columbus, $\mathrm{OH} 43201$ \\ Robert E. Meyer \\ Oak Ridge National Laboratory \\ P.0. Box X \\ Oak Ridge, TN 37830 \\ Sheldon Meyers \\ DOE Office of Nuclear Waste \\ Management \\ Washington, DC 20545 \\ Don Moak \\ Office of Nuclear Waste \\ Isolation \\ Battelle Memorial Institute \\ 505 King Avenue \\ Columbus, $\mathrm{OH} 43201$ \\ Martin A. Molecke \\ Nuclear Waste Experimental \\ Programs \\ Division 4512 \\ Sandia Laboratories \\ Albuquerque, NM 87185 \\ J. E. Monsees \\ Office of Nuclear Wate \\ Isolation \\ Battelle Memorial Institute \\ 505 King Avenue \\ Columbus, $\mathrm{OH} 43201$ \\ Jim P. Murray \\ Harvard University \\ Pierce Hall \\ Cambridge, MA 02138
}


No. of

Copies

Jeff 0 . Neff

Department of Energy

Columbus Program Office

505 King Avenue

Columbus, $\mathrm{OH} 43201$

R. M. Neilson, Jr.

Department of Applied Science

Brookhaven National Laboratory

Upton, NY 11973

Edward Norris

Los Alamos Scientific Laboratory

Group CNC-11 MS-514

P.0. Box 1663

Los Alamos, NM 87545

E. J. Nowak

Sandia Laboratory

Division 5824

Albuquerque, NM 87131

Oak Ridge National Laboratory

Central Research Library

Document Reference Section

Oak Ridge, TN 37830

G. Dertel

DOE Office of Nuclear Waste Management

Washington, DC 20545

Edward O'Donne 11

U.S. Nuclear Regulatory

Commission

Office of Standards Development

Washington, DC 20555

W. M. Pardue

Office of Nuclear Waste Isolation

Battelle Memorial Institute

$505 \mathrm{King}$ Avenue

Columbus, $\mathrm{OH} 43201$
No. of

Copies

George A. Parks

Standford University

Department of Applied Earth Sciences

Stanford, CA 94305

A. F. Perge

DOE Office of Nuclear Waste Management

Washington, DC 20545

John Pomeroy, Tech. Sec.

National Academy of Sciences

Committee of Radioactive Waste Mgmt.

National Research Council

2101 Constitution Avenue

Washington, DC 20418

R. G. Post

College of Engineering

University of Arizona

Tucson, AZ 85721

Gary A. Robbins

Department of Geology

Texas A\&M University

College Station, Texas

R. A. Robinson

Office of Nuclear Waste Isolation

Battelle Memorial Institute

$505 \mathrm{King}$ Avenue

Columbus, $\mathrm{OH} 43201$

Savannah River Laboratory

Reference Library

Aiken, SC 29801

Martin Seitz

Argonne National Laboratory

9700 South Cass Avenue

Argonne, IL 60439 
No. of

Copies

B. Scheetz

210 materials Research Laboratory

Pnnsylvania State University University Park, PA 16802

Robert Silva Lawrence Berkeley Laboratory University of California One Cyclotron Road Building 70A/1160 Berkeley, CA 94720

M. J. Steindler Chemical Engineering Division Argonne National Laboratory 9700 South Cass Avenue Argonne, IL 60439

David B. Stewart National Center 959 U.S. Geological Survey Reston, VA 22092

John D. Tewhey

Lawrence Livermore Laboratory P.0. Box 808

Livermore, CA 94550

Daryl Tweeton

U.S. Bureau of Mines

P.0. Box 1660

Twin Cities, MN 55111

Robert L. Watters

DOE Division of Ecological Sciences

Washington, DC 20545

Homer Weed

Lawrence Livermore Laboratory

University of California

P.0. Box 808

MS-L233

Livermore, CA 94550
No. of

Copies

Allen Weiss

Brookhaven National Laboratory

Building 830

Upton, NY 11973

William B. White

Materials Research Laboratory

Pennsylvania State University

University Park, PA 16802

W. A. Williams

Office of Radiation Programs

Environmental Protection Agency

Washington, DC 20460

Wilste Library

NRC

Washington, DC 20555

Kurt Wolfsberg

Los Alamos Scientific Laboratory CNC-11, MS 514

Los Alamos, NM 97545

H. Tom Yolken

National Bureau of Standards

Physics Building/B320

Washington, DC 20234

ONSITE

5 DOE Richland Operations Office

0. J. Elgert

H. E. Ransom

J. J. Schreiber

F. R. Standerfer

M. W. Shupe

4 Hanford Engineering Deve Topment Laboratory

E. T. Weber

R. J. Cash

R. L. Fish

A. C. Leaf 
No. of

Copies

11 Rockwe 11 Hanford Operations
D. J. Brown
G. S. Barney
W. Coons
F. N. Hodges
B. J. Wood
M. I. Wood
R. C. Routson
P. F Salter
M. J. Smith
W. Price
S. Price

103 Pacific Northwest Laboratory

L. L. Ames

D. J. Bradley (10)

T. D. Chikalla

M. 0 . Cloninger

W. J. Deutsch

F. H. Dove

J. H. Jarrett

Y. B. Katayama

M. R. Kreiter

K. M. Krupka

W. L. Kuhn

D. E. Larson/E. Wheelwright
No. of

Copies
I. S. Levy

J. L. McElroy/R. E. Nightingale

G. L. McVay

R. D. Nelson/W. A. Ross/

0. F. Hill

C. R. Palmer/R. O Lokken/

A. D. Chockie/G. B. Mellinger

P. R. Partsch

R. D. Peters

A. M. Platt

D. Rai

J. F. Relyea

J. M Rusin/R. P. May

R. J. Serne

J. W. Shade (20)

R. G. Strickert

R. P. Turcotte/D. M. Strachen

R. A. Walter

C. W. Washburne

R. W. Westerman/L. A. Charlot/ L. A. Chick

Technical Information Library (3)

Publishing Coordination BE (2)

Water and Land Resources

Department Library (40) 
